\title{
4-hydroxy-2-nonenal antimicrobial toxicity is neutralized by an intracellular pathogen.
}

Hannah Tabakh ${ }_{1}$, Adelle P. McFarland 1,2 , Alex J. Pollock1, Rochelle C. Glover ${ }_{1}$, Joshua J. Woodward1 ${ }^{*}$

4 1Department of Microbiology, University of Washington, Seattle, WA 98195, US

5 2Molecular and Cellular Biology Program, University of Washington, Seattle, WA 98195, US

$6 \quad{ }^{*}$ correspondence: jjwoodwa@uw.edu

\section{Abstract}

Pathogens encounter numerous antimicrobial responses, including the reactive oxygen species (ROS)

burst. ROS-mediated oxidation of host membrane poly-unsaturated fatty acids (PUFAs) generates the toxic alpha-beta carbonyl 4-hydroxy-2-nonenal (4-HNE). Though studied extensively in the context of sterile inflammation, 4-HNE's role during infection remains limited. Here we found that 4-HNE is generated during bacterial infection and that the intracellular pathogen Listeria monocytogenes induces a specific set of genes in response to 4-HNE exposure. A component of the L. monocytogenes 4-HNE response is the expression of the genes rha1 and rha2 which code for two NADPH-dependent oxidoreductases that collectively counter 4-HNE toxicity. Heterologous expression of rha1/2 in Bacillus subtilis significantly increased bacterial resistance to 4-HNE both in vitro and following phagocytosis by murine macrophages.

Our work demonstrates that 4-HNE is a previously unappreciated component of ROS-mediated toxicity and that $L$. monocytogenes has evolved specific countermeasures to survive within its presence.

\section{Introduction}

Innate immune detection of bacterial infection initiates a complex inflammatory response characterized by production of cytokines and small molecule mediators involved in driving antimicrobial immunity. A key aspect of intrinsic cellular immunity is the production of highly reactive molecules, including reactive oxygen (ROS) and nitrogen (RNS) species (Nathan and Cunningham-Bussel 2013). Unlike the highly specific targeting of infectious agents by adaptive immune responses, ROS and RNS exhibit indiscriminate toxicity toward biological systems through their capacity to react with lipid, amino acid, and nucleic acid moieties that are conserved among both eukaryotic host and invading microbe (Patel et al. 
1999, Jacobson 1996). While such indiscriminate noxious metabolite production provides protection against infection, many bacterial pathogens have evolved a diverse array of mechanisms to directly detoxify or repair damaged cellular components following ROS and RNS encounters (Fang 2004, Staerck, et al. 2017). ROS and RNS encompass a broad group of distinct molecules. While nitric oxide, hydrogen peroxide, hypochlorite, and superoxide are well characterized molecular components of the innate immune response, these molecules give rise to numerous secondary metabolites that may also contribute to host defense against infection. An initial characteristic of the inflammatory response is the mobilization of arachidonic acid from cellular membranes. While typically involved in generation of eicosanoids, arachidonic acid exposure to oxygen radicals derived from the ROS burst leads to peroxide-mediated structural rearrangement and the generation of breakdown products, the best studied of which is 4-hydroxy-2-nonenal (4-HNE), a highly reactive membrane-permeable molecule (Hanna and Hafez, 2018). Over the last 40 years, the production of 4-HNE has been well documented at sites of sterile inflammation and has been associated with many disease pathologies, including atherosclerosis (Uchida et al., 1994), Alzheimers' (Sayre et al., 2002), diabetes (Pillon et al., 2012), obstructive pulmonary disease (Rahman et al., 2002) and chronic liver disease (Paradis. et al., 1997). Although arachidonic acid mobilization and reactive oxygen species generation are well-known and well-studied components of innate immune responses, there are a dearth of studies characterizing the role of $4-\mathrm{HNE}$ during infectious disease.

In this study, we demonstrate that 4-HNE is generated during bacterial infection both in cell culture and in vivo, is able to penetrate the bacterial cell envelope and access the cytoplasm, and that 4-HNE generation leads to bacterial growth delay or death. We observed that the intracellular bacterial pathogen Listeria monocytogenes is highly resistant to the bactericidal effects of $4-\mathrm{HNE}$ and that several specific transcriptional responses are induced in response to toxic 4-HNE exposure, including two enzymes, rha1 and rha2, whose loss sensitizes L. monocytogenes to 4-HNE toxicity. When rha1/2 are expressed in the 4HNE sensitive and avirulent organism B. subtilis, they significantly increase bacterial survival in the presence of 4-HNE both in vitro and following phagocytosis by murine macrophages. Our findings are consistent with the premise that 4-HNE is a heretofore unrecognized component of ROS-mediated antimicrobial defense and that pathogens have specific and multifaceted detoxification systems used to evade 4-HNE-mediated cytotoxicity in order to promote infection. 
Results

\section{4-HNE accumulates during L. monocytogenes infection.}

4-HNE is a highly reactive electrophilic $\alpha \beta$-unsaturated aldehyde that undergoes Michael addition with nucleophilic amino acids, resulting in stable conjugates that correlate with cellular levels of free 4-HNE.

Monoclonal antibodies to these adducts are routinely used to monitor 4-HNE levels in cells (Majima,

Nakanishi-Ueda, and Ozawa. 2002). To investigate 4-HNE production during bacterial infection, we infected

murine hepatocytes with L. monocytogenes and quantified 4-HNE conjugates using dot blots of whole cell

lysates at various times post-infection. During the course of a 24-hour infection, a continuous increase in 4-

HNE protein conjugates relative to $\beta$-actin control was observed (Fig $1 \mathrm{~A})$. To interrogate the impact of

bacterial infection on host production of 4-HNE in vivo, mice were infected intravenously with $L$.

monocytogenes constitutively expressing GFP. At 48 hours post infection, tissues were harvested, fixed,

and analyzed by immunohistochemistry. Clear foci of infection were visible in the liver with no change in the

abundance of 4-HNE protein conjugates (Supp Fig 1A-D). In the spleen, however, the bacteria were

diffusely distributed throughout the organ and the entire spleen of the infected mouse exhibited increased staining for 4-HNE protein conjugates (Figs 1B-E).

The grossly different observations between the liver and spleen were somewhat surprising given our

previous observation that infection of murine hepatocytes with L. monocytogenes in vitro induced accumulation of 4-HNE conjugates. These observations are likely a consequence of several factors. The liver is a major site of small molecule detoxification and hepatocytes are known to produce high levels of many of the 4-HNE metabolizing proteins, including aldo-keto reductases, alcohol dehydrogenase, and the 4-HNE glutathione transferase, GSTA4 (Zheng et al, 2014). Additionally, the immune driven mobilization of arachidonic acid and ROS precursors that lead to 4-HNE generation may result in elevated accumulation of this host aldehyde in the spleen.

At higher levels of magnification, we observed that 4-HNE conjugates were not evenly distributed 
consistent with 4-HNE conjugate formation on the bacteria. While these observations do not provide

quantitative measures of $4-\mathrm{HNE}$ levels, they establish that $4-\mathrm{HNE}$ was indeed elevated following bacterial

infection and suggest that bacteria encounter and may be directly chemically modified by this metabolite during infection.

A

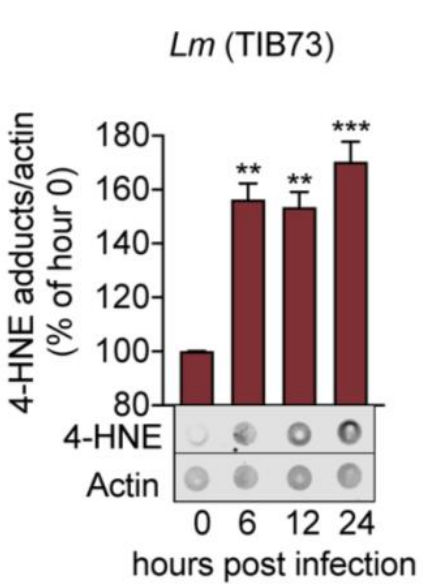

$\mathrm{F}$

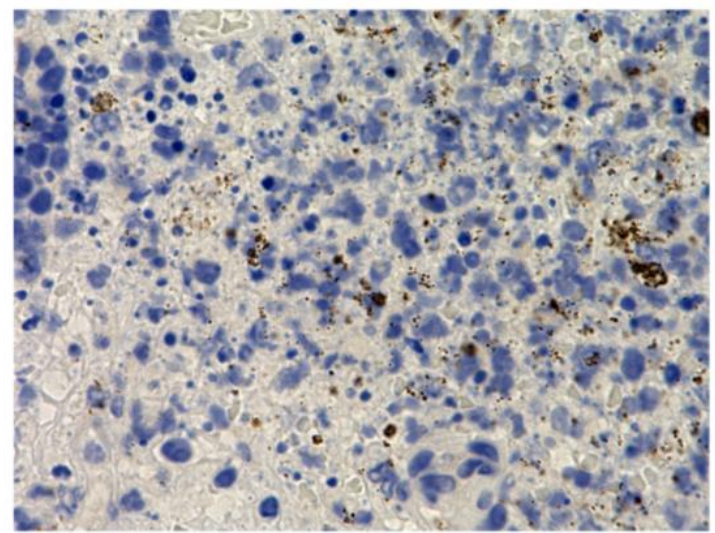

D
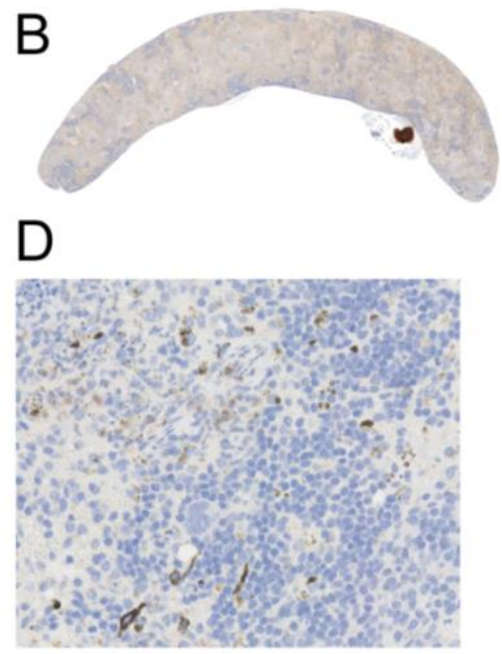

G

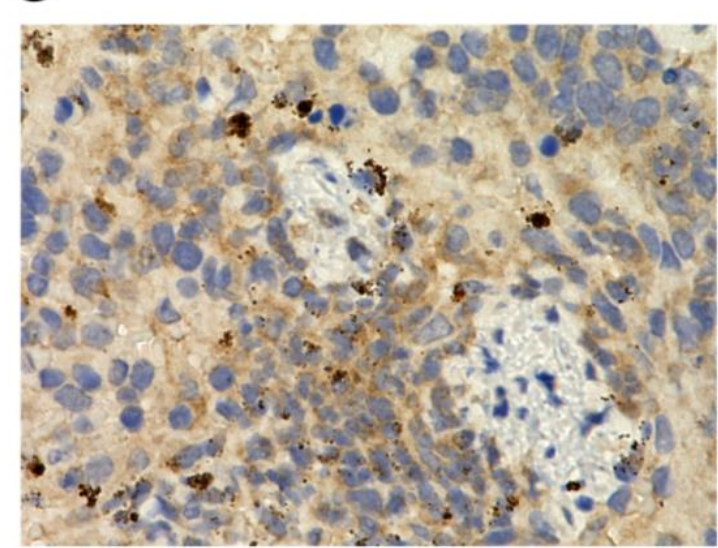

Fig 1. 4-HNE accumulates during intracellular bacterial infection by $L$. monocytogenes.

(A) 4-HNE accumulation in TIB73 murine hepatocytes during intracellular L. monocytogenes infection. 4HNE adduct accumulation is assessed by dot blot whole cell Western and normalized to actin levels. Data are normalized 4-HNE levels as percent of 4-HNE at hour 0 of infection. Western image below is representative. (B) 4-HNE accumulation during 48-hour murine infection by GFP + L. monocytogenes assessed by immunohistochemistry analysis. Spleen (infected) anti-4-HNE. (C) spleen (uninfected) anti-4HNE. (D) spleen (infected) anti-GFP 25x magnification. (E) spleen (infected) anti-4-HNE 25x magnification (F) spleen (infected) anti-GFP 100x magnification. (G) spleen (infected) anti-4-HNE 100x magnification. Antigens detected with 3,3-diaminobenzidine staining by horseradish peroxidase and cellular nuclei imaged with Hematoxylin counterstain. Data in (A) are pooled from two independent experiments. Statistics in $(A)$ are an ordinary one-way ANOVA with a Dunnett's multiple comparison test against hour 0 . Error bars are mean +/-SD. ${ }^{*}, p<0.05 ;{ }^{* *}, p<0.01 ;{ }^{* *}, p<0.001$. 
4-HNE causes damage through the targeting of nucleophilic protein moieties and $L$. monocytogenes

is uniquely resistant to 4-HNE-mediated death.

Electrophilic stress due to 4-HNE conjugation to proteins causes eukaryotic cells to undergo apoptosis following intermediate $4-\mathrm{HNE}$ exposure $(5-40 \mu \mathrm{M})$ and necrosis at higher concentrations (40$100 \mu \mathrm{M})$ (Dalleau et al., 2013). However, due to 4-HNE's lipophilicity it is believed to accumulate to significantly higher levels $(0.3-5 \mathrm{mM})$ near and within membranes than what is typically considered cytotoxic (Zimniak, 2011; Esterbauer, Schaur and Zollner, 1991; Uchida, 2003).

To characterize bacterial sensitivity to 4-HNE toxicity, we exposed bacteria within the Firmicutes phylum to a wide range of 4-HNE concentrations and assessed viability. We observed variability in survival, ranging from a 4-log reduction in CFU for B. subtilis, a 2-log reduction for Staphylococcus aureus, a half-log reduction for Enterococcus faecalis to less than a 40\% reduction for L. monocytogenes (Fig $2 \mathrm{~A})$. We observed a dose dependent decrease in growth of L. monocytogenes with increased exposure to 4-HNE (Fig 2B). The significant resistance of L. monocytogenes to 4-HNE exposure was unexpected. Due to the conserved nature of 4-HNE targets, we hypothesized that 4-HNE would exert similar damaging effects on bacteria as on eukaryotic cells. Thus, we first interrogated the ability of 4-HNE to generate protein adducts in L. monocytogenes. Dot blots of L. monocytogenes bacterial cell lysates indicated an increase in 4-HNEprotein adducts that correlated with increased 4-HNE exposure (Fig 2C), establishing that this aldehyde penetrates the bacterial cell envelope and impacts cytosolic proteins.

4-HNE adduct accumulation can result in protein misfolding and crosslink-induced aggregation.

Eukaryotic cells clear 4-HNE damaged proteins through proteasome and autophagy-mediated pathways (Zhang and Forman, 2017). Bacteria target damaged proteins for degradation through the proteases that comprise the heat shock response (Parsell and Lindquist, 1993). This pathway is primarily transcriptionally regulated (Yura, Nagai and Mori, 1993), so RT-qPCR was performed on a subset of heat shock genes representing two major groups of heat shock genes in L. monocytogenes: HrcA-regulated chaperones and CtsR-regulated proteases (Roncarati and Scarlato, 2017). When L. monocytogenes was exposed to $640 \mu \mathrm{M}$ to vehicle controls (Fig 2D). These data, combined with the dot blot results, support the hypothesis that 4- 
induction of cellular proteases relative to chaperones may indicate that $L$. monocytogenes primarily combats electrophilic 4-HNE stress through turnover of damaged proteins rather than chaperone-mediated stabilization. Collectively, these observations suggest that despite formation of protein adducts and delayed growth following exposure, L. monocytogenes has a uniquely robust capacity to survive 4-HNE toxicity even among closely related organisms.
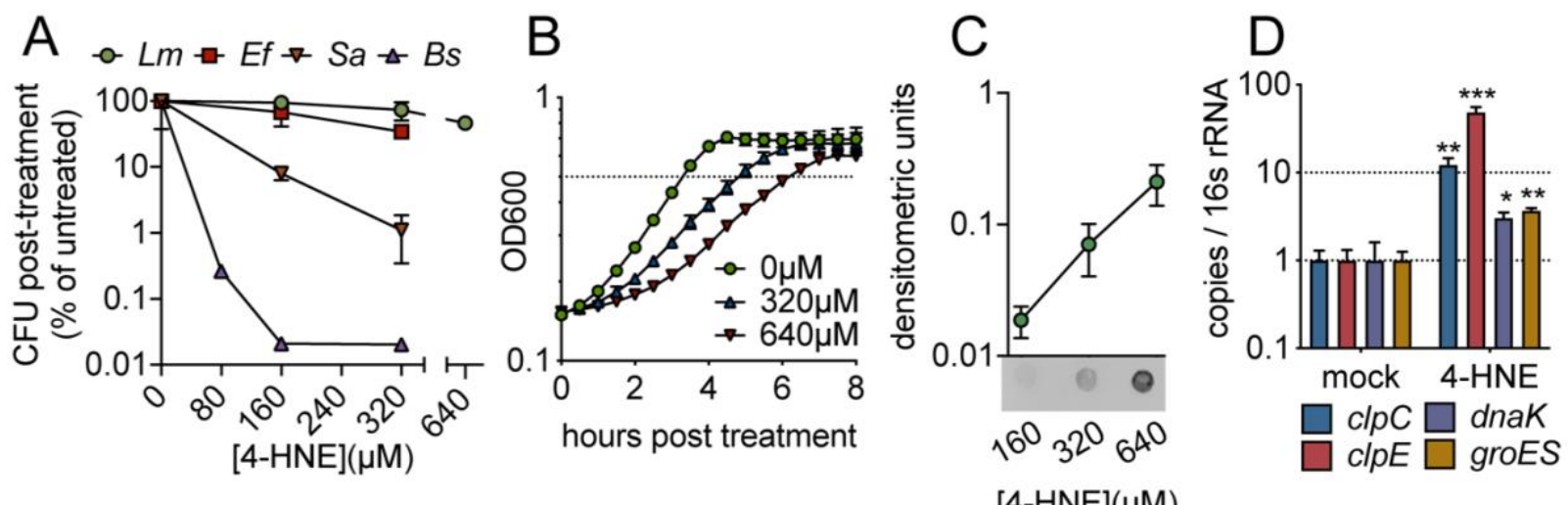

Fig 2. 4-HNE impacts bacterial viability, replication and damage to cellular proteins.

(A) Survival of mid-log (0.4-0.8OD) Listeria monocytogenes $(\mathrm{Lm})$, Enterococcus faecalis (Ef), Staphylococcus aureus ( $\mathrm{Sa}$ ) and Bacillus subtilis (Bs) following exposure to various concentrations of $4-\mathrm{HNE}$ or mock vehicle (ethanol) in PBS at $37^{\circ} \mathrm{C}$ for 1 hour. Data are reported as recovered CFU normalized to mock treated controls. (B) Growth of $L$. monocytogenes in TSB at $37^{\circ} \mathrm{C}$ with various concentrations of 4-HNE added at time zero. (C) Anti-4-HNE dot blot of soluble bacterial lysates from mid-log L. monocytogenes suspended in PBS and treated with increasing concentrations of 4-HNE for

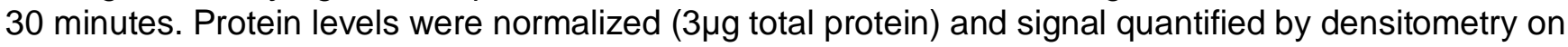
a Licor Odyssey Fc. (D) qRT-PCR measurement of expression of indicated genes in midlog $L$. monocytogenes in TSB treated with $640 \mu \mathrm{M} 4-\mathrm{HNE}$ for 20 minutes. Expression normalized to 16S rRNA levels. Data in figures $(A)$ and $(B)$ are in biological triplicate. Data in (C) and (D) are biological duplicate. Statistics for (D) are unpaired t-tests of $\Delta \Delta$ Ct values of treated samples versus untreated samples for each gene. Error bars are mean +/- SD. * $p<0.05, p<0.01 ;{ }^{* *}, p<0.001$.

\section{L. monocytogenes expresses potential 4-HNE detoxification enzymes that contribute to its survival}

in the presence of 4-HNE.

Our data suggest that L. monocytogenes is exposed to 4-HNE during infection and that only high concentrations of this aldehyde impact its growth. We hypothesized that $L$. monocytogenes may express genes involved in countering the cytotoxic effects of 4-HNE. To probe further, we performed global transcriptome analysis during 4-HNE exposure using RNA sequencing. Over one hundred genes were 
Eukaryotic cells utilize several reductases to detoxify 4-HNE (Mol et al., 2017). Two reductases were

highly induced in our global transcriptome, Imo0103 and Imo0613, which we refer to as rha1 and rha2 (resistance to host alkenals 1 and 2), respectively. Phyre2 analysis of Rha1 predicted high structural homology to CLA-ER, a flavin-dependent enone reductase from Lactococcus plantarum (PDB: 4QLY)(Hou et al, 2015). A Phyre2 analysis of Rha2 revealed structural similarity to a few crotonyl-CoA carboxylase/reductases (PDBs: 3KRT, 4YOK, and 5A3J) and a plant chloroplast oxoene reductase (PDB: 5A3V), two enzymes with the capacity to reduce enone-containing lipophilic substrates. Given the predicted reductase activity of Rha1 and Rha2 and their structural similarity to proteins that metabolize enonecontaining compounds, we further investigated their role in 4-HNE resistance.

Induction of rha1 and rha2 in response to 4-HNE exposure was found to be 34 and 90 -fold, respectively, by RT-qPCR. To assess the specificity of their induction, we exposed $L$. monocytogenes to a sublethal concentration of a panel of aldehydes (Suppl Fig 2B,C), including 4-HNE; 4-HHE (4-hydroxy-2hexenal), a similar but shorter chain $\alpha \beta$-unsaturated aldehyde produced from the oxidation of $\omega-3$ fatty acids (Awada et al., 2012); methylglyoxal, a reactive byproduct of glycolysis; propionaldehyde, an alpha hydrogen aldehyde; and malondialdehyde, another product of lipid peroxidation (Esterbauer, Schaur, and Zollner, 1991). Both rha1 and rha2 were most strongly induced by 4-HNE exposure, with much less induction by 4HHE and negligible induction with the other tested compounds (Fig 3B). We next assessed if these genes are induced by $L$. monocytogenes during intracellular infection. At 6 hours post-infection of macrophages we found that there was significant induction of both genes compared to growth in $\mathrm{BHI}$ broth (Fig $3 \mathrm{C}$ ). Together these transcriptional studies suggested that the rha1/2 genes are not components of a general aldehyde response but rather specific responses to 4-HNE encountered during infection.

These intriguing transcriptional results suggested that rha1 and rha2 may function in 4-HNE resistance. Individual and double mutants of these genes were generated and assessed by competition experiments for survival relative to WT L. monocytogenes following 4-HNE exposure. Control mixtures left untreated in PBS exhibited no significant difference between mutant and control strains (Suppl Fig 2D). 


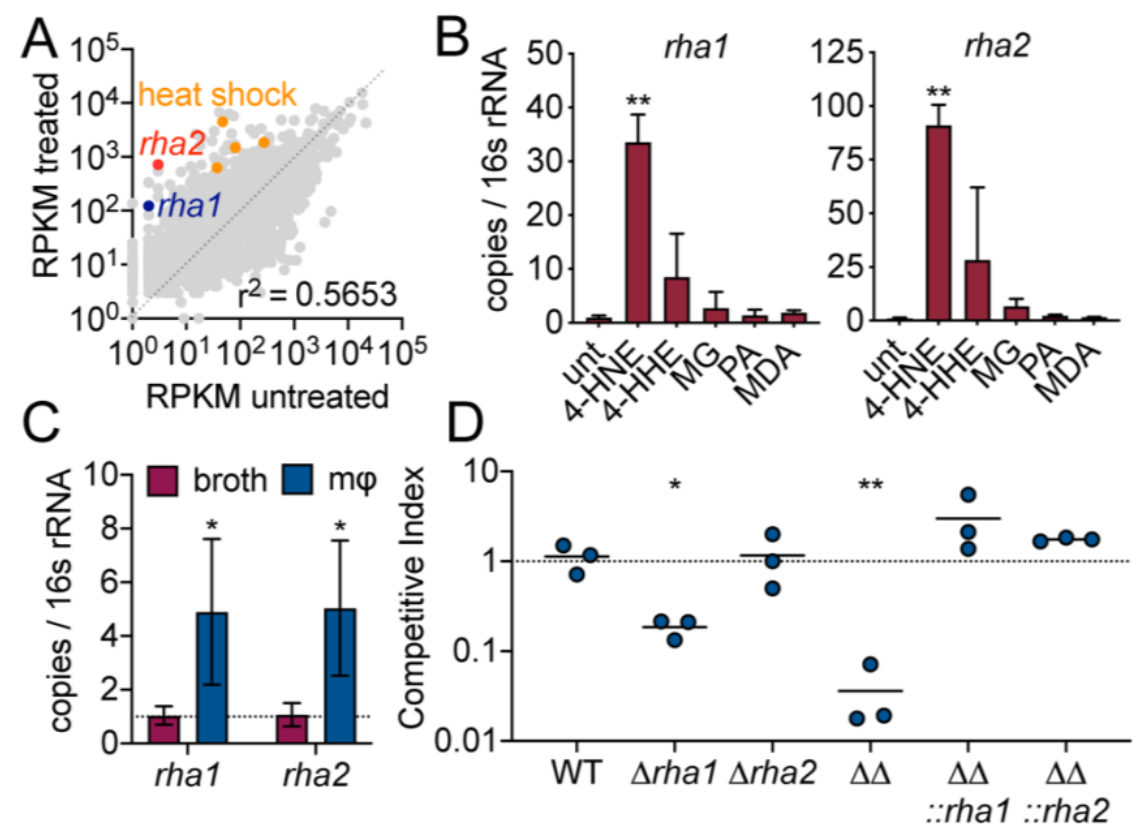

Fig 3. 4-HNE exposure induces resistance genes in L. monocytogenes.

(A) Global gene expression of midlog L. monocytogenes in TSB treated with $640 \mu \mathrm{M} 4-\mathrm{HNE}$ or ethanol control for 20 minutes. RPKM: reads per kilobase million. Genes of interest rha1, rha2 and heat shock class members are indicated in blue, red and orange, respectively. (B) qRT-PCR of expression of rha1 and rha2 genes after 20-minute treatment of mid-log bacteria in TSB media with $500 \mu \mathrm{M}$ of selected aldehydes: 4-HNE (4-hydroxy-2-nonenal), 4-HHE (4-hydroxy-2-hexenal), MG (methylglyoxal), PA (propionaldehyde) and MDA (malondialdehyde). (C) qRT-PCR analysis of expression of rha1 and rha2 at 6 hours post infection in $\mathrm{J} 774$ macrophages $(\mathrm{m} \varphi)$. (D) Competitive index of midlog WT and mutant L. monocytogenes in PBS treated with $640 \mu \mathrm{M} 4-\mathrm{HNE}$ at $37^{\circ} \mathrm{C}$ for one hour. Data in figures (A) and (B) are in biological duplicate. $(C)$ is in biological triplicate. (D) is in technical triplicate, representative of at least two independent experiments. Statistics in (B) is an ordinary one-way ANOVA with Dunnett's multiple comparison test of $\Delta \Delta \mathrm{Ct}$ values of the treated samples against untreated samples. Statistics in (C) are unpaired t-test between broth and macrophage samples. Statistics in (D) are unpaired t-test between WT and mutant L. monocytogenes competition pairs. Error bars are mean +/- SD. * $p<0.05$; $* *, p<0.01$.

Among mixtures exposed to $640 \mu \mathrm{M}$ 4-HNE, unmarked WT and marked WT showed no significant

difference in 4-HNE survival. Loss of rha2 had no effect on 4-HNE survival while $\Delta$ rha1 had a modest 5-fold

reduction relative to WT. However, the $\Delta$ rha1 1 rha2 mutant exhibited a 50-fold competitive defect compared

to WT L. monocytogenes that was rescued by either rha1 or rha2 expression in trans, demonstrating that

both genes must be absent for the toxic effect to manifest (Fig 3D). The $\Delta$ rha1 $1 \Delta$ rha2 L. monocytogenes was

used to infect macrophages and mice. During cellular infection, we observed a $\sim 50 \%$ reduction in CFU at 2

164 hours post-infection (Suppl fig 2E), which rebounded to WT levels at later time points. In mice infected via

intravenous injection no significant phenotype was observed at 48 hours post infection in either the spleen 
for 4-HNE resistance, though other factors likely contribute to $L$. monocytogenes capacity to counteract this 168 metabolite in vivo.

\section{Recombinant Rha1 and Rha2 metabolize 4-HNE and ectopic expression confers 4-HNE resistance to} sensitive bacteria.

In order to determine if these putative enone reductases can directly utilize 4-HNE as a substrate, we generated recombinant Rha1 and Rha2 proteins. As controls for these studies, we generated catalytically dead variants of the two proteins by mutating amino acids predicted to be involved in flavin or NADPH binding (Suppl Fig 3A). All proteins were expressed and characterized for NADPH oxidation in the presence and absence of 4-HNE. Only the WT variants of Rha1 and Rha2 exhibited NADPH oxidation upon addition of 4-HNE (Fig 4A), consistent with their capacity to mediate NADPH dependent reduction of the enone.

We hypothesized that Rha1 and Rha2 could confer 4-HNE resistance to a sensitive organism. To this end, each gene and corresponding catalytically dead variant were expressed individually and in combination in B. subtilis, which exhibited 300 -fold more sensitivity than L. monocytogenes upon 4-HNE exposure (Fig 2A, suppl fig 3B). Consistent with our observations of the L. monocytogenes rha deletion mutants, expression of rha2 in B. subtilis had no effect on growth in the presence of 4-HNE, rha1 gave modest protection against $640 \mu \mathrm{M}$ 4-HNE, and expression of both rha1 and rha2 had the largest growth rescue, reducing lag time by up to 3 hours (Suppl Fig 3C, Fig 4B). We then focused on B. subtilis expressing both rha1 and rha2 genes, as this strain had the most robust phenotype. When assessed for bacterial survival following 4-HNE treatment, $B$. subtilis expressing the functional enzymes exhibited nearly a 2-log survival advantage relative to the control strain expressing enzymatically dead rha1/2 (Fig 4C). Additionally, soluble cellular fractions from B. subtilis exposed to 4-HNE and probed for 4-HNE protein adducts by dot blot revealed a $\sim 70 \%$ reduction in $4-\mathrm{HNE}$ conjugates in the $B$. subtilis strain expressing both of the active rha1 and rha2 genes versus their catalytically dead counterparts (Suppl Fig 3D, Fig 4D). To determine if $4-\mathrm{HNE}$ resistance conferred by rha1/2 could contribute to bacterial survival within mammalian cells, B. subtilis rha1/2 strains were assessed for viability following phagocytosis by primary 
195 Rha2 maintained a significantly higher CFU over the course of eight hours than the $B$. subtilis expressing

196 the catalytically dead form (Fig 4E). To determine whether this survival advantage was due to 4-HNE

197 resistance, we measured $B$. subtilis survival within bone marrow-derived macrophages from gp $91_{\text {phox- - mice }}$

198 deficient in oxidase cytochrome b-245, which are unable to produce the reactive oxygen burst and therefore

199 4-HNE (Esterbauer, Schaur, and Zollner, 1991). Consistent with the role of rha1 and rha2 in resistance to a

200 ROS-derived factor, the protective effect of WT rha1/2 expression was eliminated in the absence of gp91phox

201 (Fig 4E). Together, these observations revealed that expression of rha1 and rha2 in B. subtilis imparts

202 resistance to $4-\mathrm{HNE}$ toxicity and impacts bacterial survival in the host cell's ROS burst.
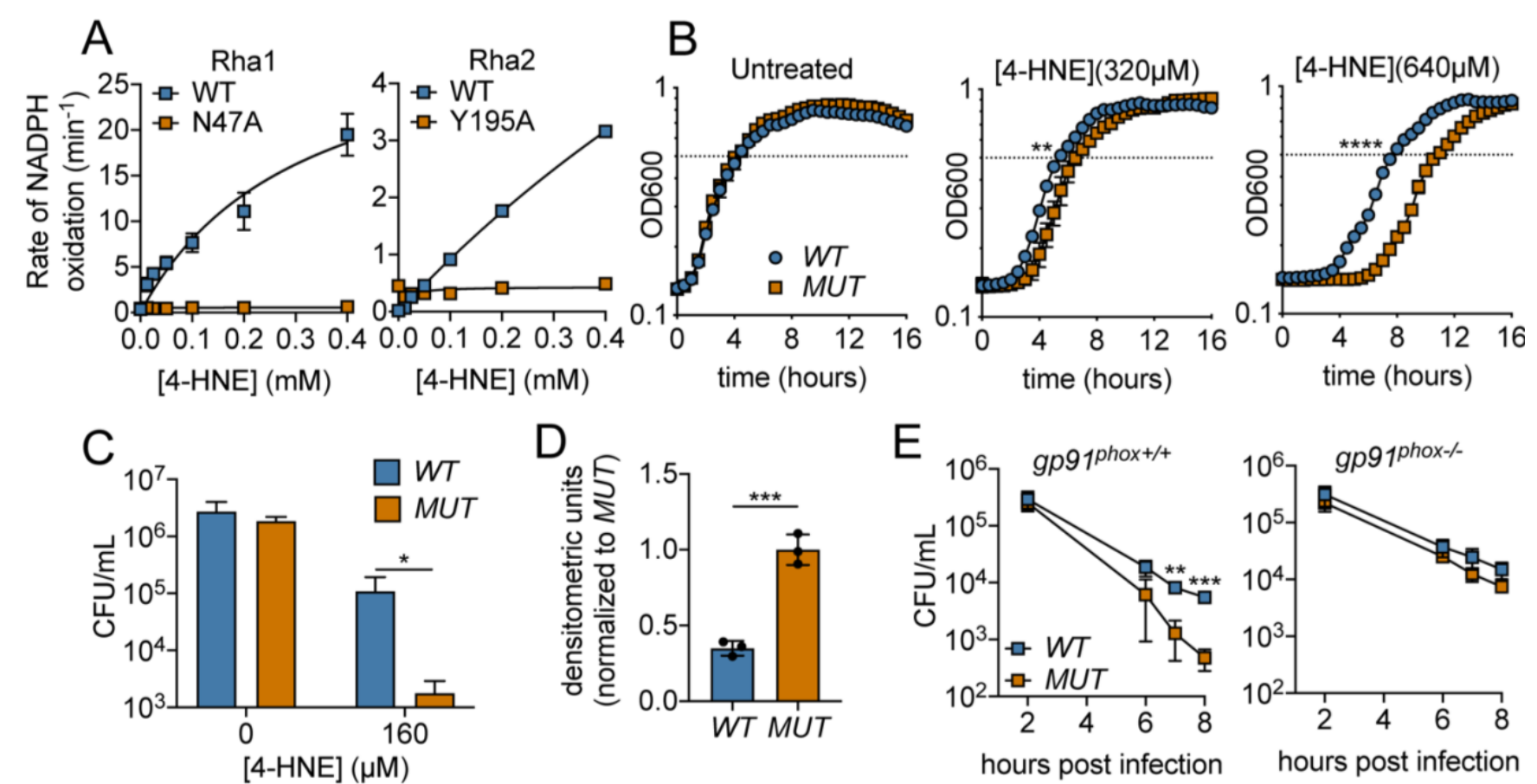

Fig 4. Recombinant Rha1 and Rha2 metabolize 4-HNE and ectopic expression confers 4-HNE resistance to sensitive bacteria. (A) Rates of NADPH oxidation $(200 \mu \mathrm{M})$ by WT and mutant variants of Rha1 and Rha2 in the presence of 4-HNE. (B) Growth of B. subtilis expressing either the WT or MUT (catalytically dead mutant) versions of rha1 and rha2 in TSB at $37^{\circ} \mathrm{C}$ in the presence of the indicated concentrations of 4-HNE added at time zero. Dotted line represents OD600 0.5. (C) Survival of

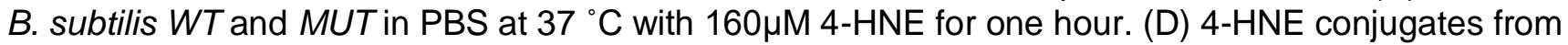
$B$. subtilis WT and MUT soluble cell lysates ( $3 \mu \mathrm{g}$ total protein) three hours after 4-HNE treatment as assessed by dot blot and quantified by densitometry on a Licor Odyssey Fc. (E) B. subtilis WT and MUT survival following phagocytosis by Interferon gamma-activated primary WT or phagosomal oxidase-deficient bone marrow derived macrophages (WT or gp91phox-/pBMMs). All experiments in figure performed in biological triplicate. Statistics in (A) are unpaired t-tests comparing the hours to OD 0.5 between WT and MUT B. subtilis pHT01::rha1/2. Statistics in (B), (C) and (D) are unpaired t-tests comparing WT and MUT B. subtilis $p H T 01::$ rha1/2. Error bars are mean +/- SD. ${ }^{*}, p<0.05 ;{ }^{* *}, p<$ $0.01 ;{ }^{* \star *}, \mathrm{p}<0.001 ;{ }^{* \star * *}, \mathrm{p}<0.0001$. 


\section{Discussion}

In this study, we provide evidence that ROS-derived metabolite 4-HNE accumulates during $L$.

monocytogenes infection both in tissue culture and in mice. We also show that 4-HNE exhibits antimicrobial effects on several bacterial species and that in the highly resistant intracellular pathogen $L$. monocytogenes, exposure to this aldehyde induces a specific and robust transcriptional profile. Among the highest induced genes are components of the heat shock response, consistent with aldehyde induced protein damage, a

\section{1}

monocytogenes results in a decrease in

viability in the presence of 4-HNE, and heterologous expression of rha1 and rha2 in $B$.

subtilis conferred increased tolerance to 4-

HNE toxicity in this non-pathogenic and 4-

HNE-sensitive organism. Rha1 and Rha2

expression in B. subtilis also allowed for

greater survival following phagocytosis by

bone marrow derived macrophages in a

manner entirely dependent upon phagocyte

ROS generation. Together this work supports

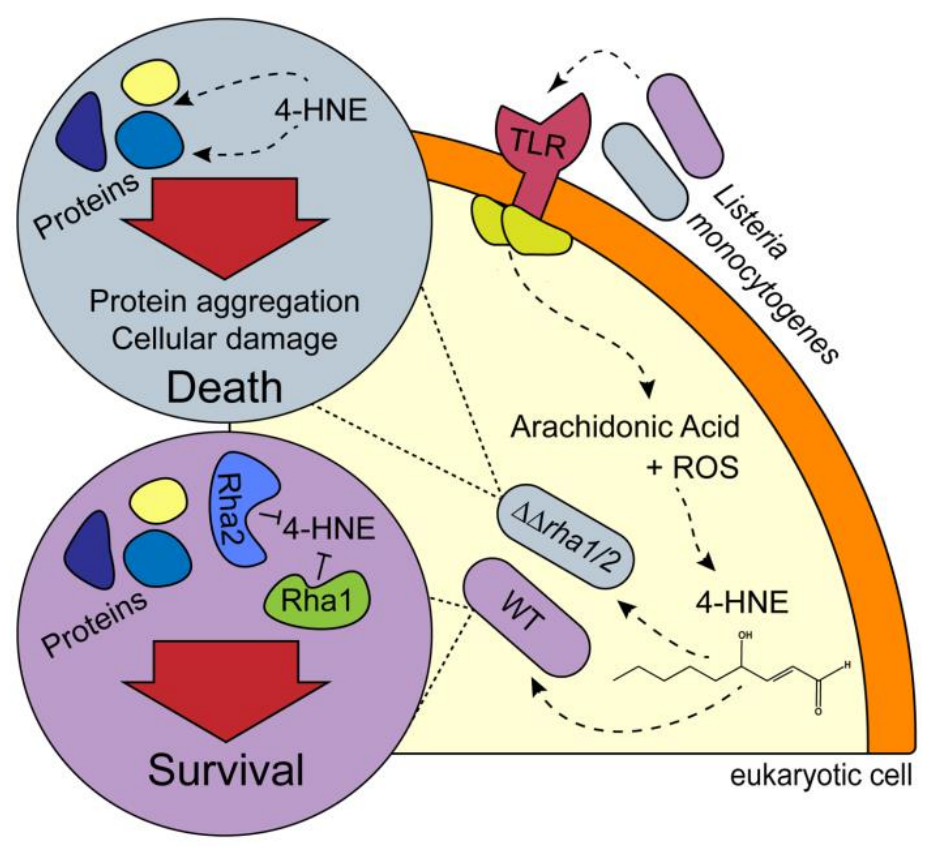

Figure 5. Model of rha1/2-mediated 4-HNE resistance in L. monocytogenes.

the conclusion that 4-HNE represents one of the individual molecular components of ROS-mediated host defense through its direct antimicrobial effects on bacteria and that pathogens have likely evolved complex mechanisms of surviving its encounter within eukaryotic hosts (Fig 5).

There are many parallels between the chemical and biological functions of 4-HNE and other toxic metabolites that function in antimicrobial defense. The freely diffusible and highly reactive diatomic gas nitric oxide (NO) is produced during infection (lyengar, Stuehr and Marletta, 1987; Stuehr and Marletta, 1985) and has a direct role in preventing bacterial growth (Nathan and Hibbs, 1991). However, due to the 
233 inflammation and acute infections (Nagafuji et al., 1995, Galley and Webster, 1998). 4-HNE is membrane

234 diffusible, highly reactive, and contributes to disease pathology due to its cytotoxic activity toward eukaryotic

235 cells. These parallels, together with our findings that bacterial infection induces 4-HNE production are

236 consistent with the premise that 4-HNE represents a component of ROS-mediated host defense, among

237 such other toxic metabolites as superoxide, hydrogen peroxide, and hypochlorite.

While a role for 4-HNE in host antimicrobial defense has yet to be appreciated in mammals, plants

utilize a variety of lipophilic molecules generated by the oxidation of polyunsaturated fatty acids (PUFAs),

collectively referred to as oxylipins. While generally considered to be involved in signal transduction, many

oxylipins can directly inhibit bacterial growth (Prost et al., 2005) and 4-HNE itself is a component of the

oxylipin burst in soybean where it serves an anti-fungal function (Vaughn and Gardner, 1993). Because 4-

HNE is one of several distinct metabolites produced following oxidation of PUFAs in mammals, it is

conceivable that other reactive byproducts of this process also contribute to microbial defense in a similar

manner.

To survive within the sterile tissues of eukaryotic hosts, bacterial pathogens often counteract the

toxic effects of the immune response. Our discovery of two genes that confer synergistic resistance to 4-

HNE in L. monocytogenes begin to provide insight into the mechanisms by which 4-HNE toxicity might be overcome. In vitro studies suggest that Rha1 and Rha2 both metabolize 4-HNE in an NADPH-dependent manner, suggesting redundant functions. Redundancy in bacterial resistance to ROS is a relatively common phenomenon, including the need to eliminate five individual enzymes in Salmonella enterica Serovar Typhimurium to exhibit a phenotype in the presence of hydrogen peroxide (Hébrard et al., 2009) and simultaneous disruption of four enzymes in Bacillus anthracis to observe a phenotype in the presence of superoxide (Cybulski et al., 2009). Such redundancy in bacterial detoxification programs likely decreases the chances that genetic drift or other genomic damage would render an organism defenseless against oxidative stress.

While Rha1 and Rha2 both contribute to 4-HNE resistance, the $\Delta r h a 1 \Delta r h a 2 ~ L$. monocytogenes strain still exhibits several logs of survival benefit relative to the related organism $B$. subtilis, suggesting that other mechanisms of 4-HNE resistance remain to be identified. Among the many uncharacterized genes 
cenocepacia which sequesters long-chain lipophilic antibiotics (El-Halfawy et al., 2017). 4-HNE, with its long

hydrophobic tail, could conceivably be neutralized in an analogous manner. It is possible many intrinsic

resistance properties of $L$. monocytogenes are not reflected through transcriptional responses. For instance, addition of amine containing constituents on the cell's surface through lysinylation of teichoic acids and/or lipids, as well as deacetylation of peptidoglycan, may provide a nucleophile reactivity barrier that prevents 4HNE entry into the bacterial cell. Additionally, $\alpha \beta$-unsaturated aldehydes have preferential reactivity toward sulfhydryl groups, including cysteine and glutathione, and it is expected that thiolate depletion would be the major mechanism of 4-HNE toxicity (Lopachin and Gavin, 2014). Indeed, the thiol responsive transcription factor spxA1 was induced $>2$-fold in response to $4-\mathrm{HNE}$ and the magnitude of heat shock gene induction mirrored results reported for $B$. subtilis following diamide treatment, a potent inducer of disulfide stress (Ole Leichert, Scharf, and Hecker, 2003). While our findings provide initial molecular insight into one pathogen's resistance to $4-\mathrm{HNE}$, it is clear that many details are yet to be revealed.

Taken together, our findings extend the range of antimicrobial molecules generated through the reactive oxygen burst to include the byproducts of lipid peroxidation. Additionally, bacteria whose infection cycles involve intimate exposure to these molecules, such as L. monocytogenes, have specific and finely regulated detoxification and protection programs against this toxicity. Future investigation of the impacts of 4-HNE on a diverse array of organisms with varied infection models will highlight the importance of this metabolite on host defense and the varied mechanisms by which pathogens counteract its toxicity to promote infection.

\section{Acknowledgements}

We thank Aruna Menon, Maureen Thomason and Qing Tang for assistance with experiments, Brian Johnson for performing the histology experiments at the Histology and Imaging Core at the University of Washington, Steven Libby for providing gp91 knockout mice and Peter Lauer and Kevin Lang for providing plasmids. We thank members of the Woodward-Reniere supergroup for helpful discussions, and the Mougous, Reniere and Lagunoff labs for reagents. This material is based upon work supported by PHS NRSA T32GM007270 from NIGMS (to HT and AJP), National Science Foundation Graduate Research 
288 Fellowship Program under grant no. DGE-1256082 (to APM), and National Institutes of Allergy and 289 Infectious Disease grants R01Al116669 and R21Al127833 (to JJW).

\section{Author Contributions}

292 HT, APM and JJW conceptualized the studies, HT, APM, AJP and RCG performed the experiments, HT and JJW wrote the original draft of the manuscript, APM, AJP and RCG edited and reviewed the manuscript, and JJW, HT, AJP and APM acquired funding. JJW supervised and administered the project.

\section{Competing Interests}

The authors declare no competing interests.

\section{Methods}

Strains and routine growth conditions

Unless otherwise specified, L. monocytogenes was grown at $37^{\circ} \mathrm{C}$ degrees in tryptic soy broth (TSB) media and E. coli at $37^{\circ} \mathrm{C}$ degrees in Luria-Bertani (LB) media with appropriate antibiotic selection. Unless otherwise noted, $B$. subtilis was struck on LB plates with appropriate antibiotics and induction agent

DNA manipulation and plasmid construction

311 All DNA manipulation procedures followed standard molecular biology protocols. Primers were synthesized and purified by Integrated DNA Technologies (IDT). HiFi polymerase (Kapa Biosystems, \#KK2102),

313 FastDigest restriction enzymes (Thermo Fisher Scientific \#FD0274) and T4 DNA ligase (Thermo Scientific \# $314 \mathrm{~K} 1423)$ were used for plasmid construction, with the exception of $p H T 01:: r h a 1 / 2 \_W T$ and 
pHT01::rha1/2_MUT which were generated using Gibson Assembly MasterMix (NEB, \#E2611S). DNA sequencing was performed by Genewiz Incorporated.

Bacterial infection dot blot

TIB73 cells were lysed in whole cell lysis buffer (50 mM Tris pH 7.5, $150 \mathrm{mM} \mathrm{NaCl}, 1 \%$ Triton X-100) with

Mouse infections

L. monocytogenes was grown overnight statically at $30^{\circ} \mathrm{C}$ degrees in Brain Heart Infusion (BHI) broth, then back-diluted using $1.2 \mathrm{~mL}$ of overnight culture to $4.8 \mathrm{~mL}$ of fresh $\mathrm{BHI}$ and grown for 1 hour at $37^{\circ} \mathrm{C}$ degrees shaking. $\mathrm{OD}_{600}$ of these cultures were taken and, using the conversion of $1 \mathrm{OD}=1.7 \times 1{ }^{\circ} \mathrm{g} \mathrm{CFU}$, diluted to $5 \times 10_{5} \mathrm{CFU} / \mathrm{mL}$ with PBS. $200 \mu \mathrm{l}$ were then injected into female mice between $6-8$ weeks of age retroorbitally ( $1 \times 10_{5} \mathrm{CFU} /$ mouse) and livers and spleens were harvested at 48 hours post infection. Livers were homogenized in $10 \mathrm{~mL}$ of cold $0.1 \%$ IGEPAL and spleens were homogenized in $5 \mathrm{~mL}$ using a Tissue Tearor Model 985370 (Biospec Products) at 10,000 RPM for 5 seconds/organ. Homogenates were diluted in PBS and plated on LB plates to enumerate CFU. All protocols were reviewed and approved by the Institutional Animal Care and Use Committee at the University of Washington. 
343 Two female mice were infected as outlined above, in addition to one uninfected control mouse. The livers

344 and spleens were harvested at 48 hours post infection and placed in $10 \%$ neutral buffered formalin for 24

345 hours, after which the organs were removed from formalin and placed in PBS for 24 hours. Paraffin

346 embedded tissues were sliced and prepared as slides. Slides were then deparaffinized for 30 minutes at

$34760^{\circ} \mathrm{C}$. All subsequent manipulations were performed on a Leica Bond Automated Immunostainer. Antigen

348 retrieval for GFP was performed by HIER 2 (EDTA) treatment for 20 minutes at $100^{\circ} \mathrm{C}$. Antigen retrieval for

$3494-\mathrm{HNE}$ was performed by citrate treatment for 20 minutes at $100^{\circ} \mathrm{C}$. Then a Leica Bond peroxide block was

350 performed for 5 minutes at room temperature, and normal goat serum (10\% in TBS) was added for 20

351 minutes at room temperature. Primary antibody was added (GFP 1:500), (Rab IgG 1:1000), (4-HNE 1:200)

352 in Leica Primary antibody diluent, for 30 minutes at room temperature. Leica Bond Polymer was added for 8

353 min at room temperature, after which the samples were washed with Leica Bond Mixed Refine (DAB)

354 detection solution twice for 10 minutes at room temperature. Hematoxylin Counterstain was added for 4

355 minutes and the samples were cleared to xylene. Finally, samples were mounted with synthetic resin

356 mounting medium on a 1.5cm coverslip and imaged with a Hamamatsu Nanozoomer Whole Slide Scanner 357 and a Keyence BZ-X710 Microscope.

\section{L. monocytogenes 4-HNE dot blots}

L. monocytogenes were sub-cultured from overnight stationary cultures 1:100 into fresh media and grown to mid-log $\left(0.4-0.8 \mathrm{OD}_{600}\right)$. The bacteria were normalized to OD 1, washed twice with sterile PBS and resuspended in sterile PBS. A range of 4-HNE concentrations were added to the bacteria and the samples were placed at $37 \mathrm{C}$ for 30 minutes. Upon completion, the bacteria were washed twice with PBS and spun at $10,000 \mathrm{~g}$ for 5 minutes, then resuspended in fresh PBS. The bacteria were then sonicated using a narrow tip sonicator at $20 \%$ power, 1 second on 1 second off for 10 seconds and placed on ice. The bacteria were then spun at $4 \mathrm{C}$ at $10,000 \mathrm{~g}$ for 30 minutes. The subsequent lysate was transferred to fresh Eppendorf tubes containing Halt Proteinase and Phosphatase Inhibitor (Thermo Fisher Scientific, \#78442) and stored at -80C until use. For the dot blots, the protein concentration was normalized using BCA (Fisher Scientific,

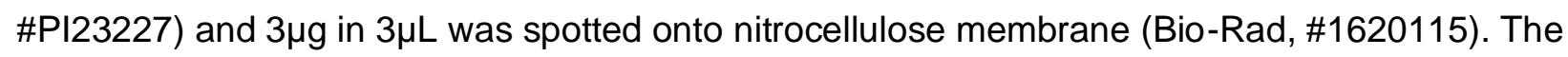


371 primary 4-HNE antibody was added at 1:200 dilution (Abcam, \#ab46545). The antibody was left on

372 overnight at $4^{\circ} \mathrm{C}$ rocking. The primary antibody was then washed off with TBS-T 3 times and secondary

373 antibody (Licor, \#926-32211) was added at 1:8000 for 45 minutes at RT. The secondary antibody was then

374 washed off with TBS-T twice, TBS once and the blot was imaged on a Licor Odyssey Fc. Relative

375 densitometric analysis was performed using Licor Image Studio software.

\section{RNA extraction from broth cultures of L. monocytogenes}

L. monocytogenes stationary phase overnights were subcultured 1:100 into fresh TSB media and grown shaking at $37^{\circ} \mathrm{C}$ to mid-log $\left(0.4-0.8 \mathrm{OD}_{600}\right)$. Then a final concentration of $640 \mu \mathrm{M} 4-\mathrm{HNE}$ (Cayman \#32100) or vehicle $\left(100 \%\right.$ ethanol) was added to the bacteria, which continued to grow at $37^{\circ} \mathrm{C}$ shaking for 20 minutes. After 20 minutes, ice cold $100 \%$ methanol was added in equal volume to the culture flask and placed at $-20 \mathrm{C}$ overnight. The next day the bacteria were spun down and resuspended in $400 \mu \mathrm{L} A E$ buffer (50mM NaOAc pH 5.2, 10mM EDTA in molecular grade water). The resuspended bacteria were then mixed

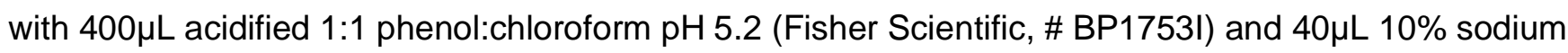
dodecyl sulfate (SDS) and was vortexed for 10 minutes in a multi-tube vortexer. The tubes were then transferred to a $65 \mathrm{C}$ heat block for ten minutes, after which the mixture was transferred to a Heavy Phaselock tube (VWR \#10847-802) and spun down for 5 minutes at 17,000g. Then the aqueous layer was transferred into tubes containing $1 \mathrm{~mL} 100 \%$ ethanol and $40 \mu \mathrm{L} 3 \mathrm{M} \mathrm{NaOAC}$ and placed at $-20 \mathrm{C}$ for 6 hours. Then tubes were spun at $17,000 \mathrm{~g}$ for 30 minutes at $4 \mathrm{C}$, the ethanol was aspirated and $500 \mu \mathrm{L} 70 \%$ ethanol was added. The tubes were then centrifuged at $17,000 \mathrm{~g}$ for 10 minutes at room temperature and the supernatant was aspirated. The RNA pellet was then dried in a speed vacuum concentrator for 5 minutes and resuspended in RNA-free molecular grade water. The extracted RNA was then treated with DNase (Ambion Life Technologies \#AM1907) for an hour at $37^{\circ} \mathrm{C}$ and used for downstream processing.

\section{RNA-sequencing}

RNA was processed using the Ovation Complete Prokaryotic RNA-Seq Library System (NuGEN, \#0363-32, 0326-32, 0327-32) according to the manufacturer's instructions to a final pooled library concentration of 3nM. Libraries were sequenced on an Illumina HiSeq 2500 (SR50) at The Genomics Resource at the Fred 
399 Hutchinson Cancer Research Center. Image analysis and base calling were performed using Illumina's Real

400 Time Analysis v1.18.66.3 software, followed by 'demultiplexing' of indexed reads and generation of FASTQ

401 files using Illumina's bcl2fastq Conversion Software v1.8.4. Reads determined by the RTA software to pass

402 Illumina's default quality filters were concatenated for further analysis. The FASTQ files were aligned and

403 analyzed using Rockhopper software (McClure et al., 2013). These data have been deposited to the GEO

404 and are accessible using accession number GSE150188.

405

406

qRT-PCR

407 Bacteria were grown in the same manner as for RNA-seq except $500 \mu \mathrm{M}$ of each aldehyde tested was 408 added to the culture at mid-log $(0.4-0.8$ OD 600$)$. The RNA was extracted by the acidified phenol method as listed above and DNase treated and reverse-transcribed using the iScript Reverse Transcription Supermix (Bio-Rad, \#1708840). SYBR Green (Thermo Fisher Scientific \# K0223) was then used to amplify genes of interest and CT values and relative expression were normalized using CFX Maestro Software (Bio-Rad $\# 12004110)$.

Intracellular RNA extraction

RNA extraction from macrophages was performed as previously described (Sigal, Pasechnek and Herskovits, 2016). J774 macrophages were seeded at a density of 2.0x107 cells/dish in three $150 \mathrm{~mm}$

dishes in $30 \mathrm{~mL}$ media and incubated overnight. The next day, overnight $L$. monocytogenes culture grown at $30^{\circ} \mathrm{C}$ was washed twice with PBS and added to the cells at a $\mathrm{MOI}$ of 50 . After one hour, the cells were washed twice with PBS and media containing gentamicin was added. Eight hours post-infection, cells were washed once with PBS and lysed by addition of cold nuclease-free water. Lysate was collected by scraping and centrifugation at $800 \mathrm{~g}$ for $3 \mathrm{~min}$ at $4^{\circ} \mathrm{C}$. Supernatants were passed through $0.45 \mu \mathrm{m}$ filters in a vacuum apparatus, and filters were collected in conical tubes. Filters were vortexed with $650 \mu \mathrm{L}$ sterile AE buffer for one minute and centrifuged briefly. Bacteria-containing AE buffer was collected and used for immediate RNA extraction as described above. 
427 Bacteria were inoculated overnight in TSB and grown at $37^{\circ} \mathrm{C}$. The next day the bacteria were subcultured

1:1000 into fresh TSB and allowed to reach mid-log (0.4-0.8 OD600). At mid-log the ODs of the bacteria were normalized to OD1, washed twice in sterile PBS and resuspended in sterile PBS. Then the bacteria were diluted 1:100 into sterile PBS in Eppendorf tubes and various concentrations of 4-HNE were added. The bacteria were then placed at $37^{\circ} \mathrm{C}$ for an hour. After an hour, the bacteria were plated on LB plates to enumerate CFU.

433

\section{L. monocytogenes competition experiments}

Colonies of $L$. monocytogenes were picked off BHI plates and inoculated into $2 \mathrm{~mL}$ TSB which was then grown shaking at $37^{\circ} \mathrm{C}$ to mid-log $\left(0.5-0.8 \mathrm{OD}_{600}\right)$. At mid-log the bacteria were normalized to $\mathrm{OD}_{600} 1$, washed twice in sterile PBS and resuspended in sterile PBS. Then the bacteria were diluted 1:100 into sterile PBS and appropriate strains were mixed together in a 1:1 ratio, after which $640 \mu \mathrm{M}$ of $4-\mathrm{HNE}$ or vehicle (ethanol) was added. The bacteria were then placed at $37^{\circ} \mathrm{C}$ for one hour. $2 \mathrm{x}$ concentrated TSB media was added to the bacterial-PBS solution and the cells recovered for an hour at $37^{\circ} \mathrm{C}$. The bacteria were then plated on $\mathrm{BHI}$-streptomycin and $\mathrm{BHI}$-chloramphenicol plates for competitive strain differentiation. CFUs were enumerated after 24-48 hours of growth.

\section{Purified protein expression and enzyme kinetics}

rha1 and rha2 ORFs were cloned into pET20B vectors and transformed into BL21 E. coli and grown overnight

in LB-ampicillin. The overnights were subcultured 1:100 in $2 \mathrm{~L}$ baffled flasks until mid-log $\left(0.5-0.8 \mathrm{OD}_{600}\right)$ after which $0.5 \mathrm{mM}$ IPTG was added. The pET20b::rha2 E. coli were induced for 4 hours at $37^{\circ} \mathrm{C}$ shaking. $0.1 \% \mathrm{w} / \mathrm{v}$ riboflavin was added to E. coli pET20B::rha1 and the flask was moved to grow at $17^{\circ} \mathrm{C}$ for 18 hours shaking. Upon completion, the bacteria were spun down, resuspended in buffer A (30mM K2HPO4, $300 \mathrm{mM} \mathrm{NaCl}, \mathrm{pH} 8$ ) and sonicated on ice with a large sonicator tip at $80 \%$ power $1 \mathrm{sec}$ on $1 \mathrm{sec}$ off for 30 seconds total. They were then spun down at $15,000 \mathrm{~g}$ for 45 minutes at $4^{\circ} \mathrm{C}$ and the supernatant was passed over a nickel resin column (Thermo Fisher Scientific, \# PI88222) and eluted using buffer B (30mM 
desalting column (Bio-Rad \#7322010). For purification of Rha1 10 $\mu$ M FMN (Sigma \#F2253) was added at every step of purification.

457 Enzyme turnover assays were performed at $37^{\circ} \mathrm{C}$ in 96 well clear bottom plates (Genesee Scientific, \#25104 ) in a Synergy HTX plate reader in $200 \mu \mathrm{L}$ PBS using $200 \mu \mathrm{M}$ NADPH, $0.2 \mu \mathrm{M}$ enzyme and a range of 4 -

HNE concentrations from 0 to $0.4 \mathrm{mM}$. Rha1 turnover was performed in the presence of $10 \mu \mathrm{M}$ FMN.

\section{B. subtilis growth curves}

B. subtilis expressing genes of interest on the pHT01 plasmid (Nguyen, Phan, and Schumann, 2007) were struck on LB-chloramphenicol plates on day 1 and grown overnight at 30C. On day 2, colonies were restruck on LB chloramphenicol IPTG $1 \mathrm{mM}$ LB plates overnight at 30C. On day 3, biomass was scraped and processed as described in the "bacterial culturing" section above. The bacteria were then normalized to an

OD 600 of 1 and inoculated 1:100 into a 96-well plate containing TSB chloramphenicol and 0.5mM IPTG. 4-

HNE was then added to the bacteria at various concentrations and the bacteria were allowed to grow at $37^{\circ} \mathrm{C}$ in Synergy HTX plate reader for 12 hours with shaking.

\section{B. subtilis 4-HNE dot blot}

B. subtilis were grown and processed in the same manner as for the growth curves above. Upon OD600 1 normalization the bacteria were resuspended in TSB-chloramphenicol with $0.5 \mathrm{mM} \mathrm{IPTG}$ and $250 \mu \mathrm{L}$ of this

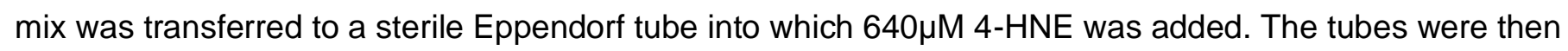
incubated at $37^{\circ} \mathrm{C}$ for 3 hours. At 3 hours, the bacteria were spun down at $17,000 \mathrm{~g}$ for 1 minute. The supernatant was then aspirated and the pellet flash frozen in liquid nitrogen. At this point, the bacteria were stored at $-80 \mathrm{C}$ until further processing. Once removed from the $-80 \mathrm{C}$, the bacteria were thawed at room temperature and resuspended in $250 \mu \mathrm{L}$ PBS. The bacteria were then sonicated using a narrow tip sonicator at $20 \%$ power, $1 \mathrm{sec}$ on $1 \mathrm{sec}$ off for 10 seconds and placed on ice. The bacteria were then spun at $4^{\circ} \mathrm{C}$ at $5,000 \mathrm{~g}$ for 10 minutes. The subsequent lysate was transferred to fresh Eppendorf tubes containing Halt Proteinase and Phosphatase Inhibitor (Thermo Fisher Scientific, \#78442) and stored at $-80 \mathrm{C}$ until use. For

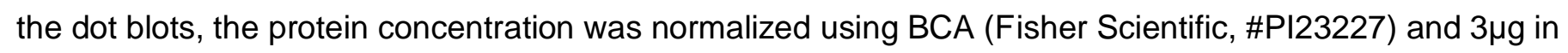
$3 \mu \mathrm{L}$ was spotted onto nitrocellulose membrane (Bio-Rad, \#1620115). The nitrocellulose was then dried, 
483 blocked for 45 minutes in 5\% dry milk, washed three times with TBS-T and primary 4-HNE antibody was 484 added at 1:200 dilution (Abcam, \#ab46545). The antibody was left on overnight at $4^{\circ} \mathrm{C}$ rocking. The primary 485 antibody was then washed off with TBS-T three times and secondary antibody (Licor, \#926-32211) was added at 1:8000 for 45 minutes at RT. The secondary was then washed off with TBST twice, TBS once, and then the blot was imaged on a Licor Odyssey Fc. Relative densitometric analysis was performed using Licor Image Studio software.

\section{L. monocytogenes macrophage infection}

$0.5 \times 106$ primary murine macrophages from WT C57BL/6 mice were plated in BMM media (DMEM with $10 \%$ heat inactivated fetal bovine serum, $1 \mathrm{mM} \mathrm{L-glutamine,} 2 \mathrm{mM}$ sodium pyruvate and $10 \%$ L929conditioned medium) in a tissue culture treated 24-well dish (Greiner Bio, \#662165) with the addition of 100ng recombinant murine IFN-y (Peprotech, \#315-05) for 18 hours. Inoculants of $L$. monocytogenes were statically grown at $30^{\circ} \mathrm{C}$ overnight, washed twice with sterile PBS and resuspended in PBS before an MOI of 0.1 was added to each macrophage well. The cells were left to sit for an hour after which all wells were washed twice with PBS and gentamicin was added to all but one well, which was lysed in $500 \mu \mathrm{L}$ water and plated for CFU on LB plates. The remainder of the wells were washed twice with PBS and then lysed and plated for CFU at hours 2, 6 and 9 post-infection.

\section{B. subtilis macrophage survival assay}

B. subtilis were grown on LB-chloramphenicol $1 \mathrm{mM}$ IPTG plates and processed into LB chloramphenicol as described above. Once the bacteria were normalized to OD 6001 in LB chloramphenicol, an MOI of 100 was added to 0.5 x 106 primary murine macrophages from WT C57BL/6 or C57BL/6 deficient for phox (gp91 phox-/) mice (The Jackson Laboratory, stock \# 002365) that have been activated using 100ng/well recombinant murine IFN-y (Peprotech, \#315-05) for 18 hours. The cells were spinfected at $200 \mathrm{~g}$ for 5 minutes. At 1.5 hours, cells were washed $2 x$ with sterile PBS and gentamicin was added to the cells. pBMMs were lysed in $500 \mu \mathrm{L}$ cold water at hours 2, 6, 7, and 8 and plated for CFU. Colonies were enumerated after overnight growth at $30^{\circ} \mathrm{C}$ on LB plates. 


\section{1}

\section{References}

512

3. Dalleau, S. et al. (2013) 'Cell death and diseases related to oxidative stress:4-hydroxynonenal (HNE) in the balance', Cell Death and Differentiation. Nature Publishing Group, pp. 1615-1630. doi: 10.1038/cdd.2013.138.

4. El-Halfawy, O. M. et al. (2017) 'Antibiotic capture by bacterial lipocalins uncovers an extracellular mechanism of intrinsic antibiotic resistance', mBio. American Society for Microbiology, 8(2). doi: 10.1128/mBio.00225-17.

5. Esterbauer, H., Schaur, R. J. and Zollner, H. (1991) 'Chemistry and biochemistry of 4hydroxynonenal, malonaldehyde and related aldehydes', Free Radical Biology and Medicine. Pergamon, pp. 81-128. doi: 10.1016/0891-5849(91)90192-6.

6. Fang, F. C. (2004) 'Antimicrobial reactive oxygen and nitrogen species: Concepts and controversies', Nature Reviews Microbiology. Nature Publishing Group, pp. 820-832. doi: 10.1038/nrmicro1004. 
7. Galley, H. F. and Webster, N. R. (1998) 'Nitric oxide in a nutshell: Genetics, physiology and pathology', Current Anaesthesia and Critical Care. Churchill Livingstone, 9(4), pp. 209-213. doi: 10.1016/S0953-7112(98)80057-4.

8. Hanna, V. S. and Hafez, E. A. A. (2018) 'Synopsis of arachidonic acid metabolism: A review', Journal of Advanced Research. Elsevier B.V., pp. 23-32. doi: 10.1016/j.jare.2018.03.005.

9. Hébrard, M. et al. (2009) 'Redundant hydrogen peroxide scavengers contribute to Salmonella virulence and oxidative stress resistance', Journal of Bacteriology. American Society for Microbiology Journals, 191(14), pp. 4605-4614. doi: 10.1128/JB.00144-09.

10. Hou, F. et al. (2015) 'Structure and reaction mechanism of a novel enone reductase', FEBS Journal. Blackwell Publishing Ltd, 282(8), pp. 1526-1537. doi: 10.1111/febs.13239.

11. lyengar, R., Stuehr, D. J. and Marlettat, M. A. (1987) Macrophage synthesis of nitrite, nitrate, and Nnitrosamines: Precursors and role of the respiratory burst ( $L$-arginine/' $5 \mathrm{~N}$ enrichment $/ \mathrm{N}$ nitrosomorpholine), Proc. Nati. Acad. Sci. USA.

12. Jacobson, M. D. (1996) 'Reactive oxygen species and programmed cell death', Trends in Biochemical Sciences. Elsevier Ltd, 21(3), pp. 83-86. doi: 10.1016/S0968-0004(96)20008-8.

14. Majima, H. J., Nakanishi-Ueda, T. and Ozawa, T. (2002) '4-hydroxy-2-nonenal (4-HNE) staining by

13. Lopachin, R. M. and Gavin, T. (2014) 'Molecular mechanisms of aldehyde toxicity: A chemical perspective', Chemical Research in Toxicology. American Chemical Society, pp. 1081-1091. doi: $10.1021 / \mathrm{tx} 5001046$. anti-HNE antibody.', Methods in molecular biology (Clifton, N.J.). Humana Press, 196, pp. 31-34. doi: 10.1385/1-59259-274-0:31. 
15. Mcclure, R. et al. (2013) 'Computational analysis of bacterial RNA-Seq data'. doi: 10.1093/nar/gkt444.

16. Mol, M. et al. (2017) ‘Enzymatic and non-enzymatic detoxification of 4-hydroxynonenal: Methodological aspects and biological consequences', Free Radical Biology and Medicine. Elsevier Inc., pp. 328-344. doi: 10.1016/j.freeradbiomed.2017.01.036.

17. Nagafuji, T. et al. (1995) 'Nitric oxide synthase in cerebral ischemia - Possible contribution of nitric oxide synthase activation in brain microvessels to cerebral ischemic injury', Molecular and Chemical Neuropathology. Humana Press, 26(2), pp. 107-157. doi: 10.1007/BF02815009.

18. Nathan, C. and Cunningham-Bussel, A. (2013) 'Beyond oxidative stress: An immunologist's guide to reactive oxygen species', Nature Reviews Immunology. Nature Publishing Group, pp. 349-361. doi: $10.1038 /$ nri3423.

19. Nathan, C. F. and Hibbs, J. B. (1991) 'Role of nitric oxide synthesis in macrophage antimicrobial activity', Current Opinion in Immunology. Elsevier Current Trends, 3(1), pp. 65-70. doi: 10.1016/0952-7915(91)90079-G.

20. Nguyen, H. D., Phan, T. T. P. and Schumann, W. (2007) 'Expression vectors for the rapid purification of recombinant proteins in Bacillus subtilis', Current Microbiology. Springer, 55(2), pp. 89-93. doi: 10.1007/s00284-006-0419-5.

21. Ole Leichert, L. I., Scharf, C. and Hecker, M. (2003) 'Global characterization of disulfide stress in Bacillus subtilis', Journal of Bacteriology, 185(6), pp. 1967-1975. doi: 10.1128/JB.185.6.19671975.2003. 
22. Paradis, V. et al. (1997) 'In situ detection of lipid peroxidation by-products in chronic liver diseases', Hepatology. John Wiley and Sons Inc., 26(1), pp. 135-142. doi: 10.1002/hep.510260118.

23. Parsell, D. A. and Lindquist, S. (1993) THE FUNCTION OF HEAT-SHOCK PROTEINS IN STRESS TOLERANCE: DEGRADATION AND REACTIV ATION OF DAMAGED PROTEINS.

24. Patel, R. P. et al. (1999) 'Biological aspects of reactive nitrogen species', Biochimica et Biophysica Acta - Bioenergetics. Elsevier, pp. 385-400. doi: 10.1016/S0005-2728(99)00028-6.

602

603

25. Pillon, N. J. et al. (2012) 'The Lipid Peroxidation By-Product 4-Hydroxy-2-Nonenal (4-HNE) Induces Insulin Resistance in Skeletal Muscle through Both Carbonyl and Oxidative Stress', Endocrinology.

604

605 Oxford Academic, 153(5), pp. 2099-2111. doi: 10.1210/en.2011-1957.

606

26. Prost, I. et al. (2005) 'Evaluation of the Antimicrobial Activities of Plant Oxylipins Supports Their Involvement in Defense against Pathogens 1[W]', Plant Physiology, 139, pp. 1902-1913. doi: 10.1104/pp.105.066274.

27. Rahman, I. et al. (2002) '4-Hydroxy-2-nonenal, a specific lipid peroxidation product, is elevated in lungs of patients with chronic obstructive pulmonary disease', American Journal of Respiratory and Critical Care Medicine, 166(4), pp. 490-495. doi: 10.1164/rccm.2110101.

29. Sayre, L. M. et al. (2002) ‘4-Hydroxynonenal-Derived Advanced Lipid Peroxidation End Products Are

28. Roncarati, D. and Scarlato, V. (2017) 'Regulation of heat-shock genes in bacteria: from signal sensing to gene expression output', FEMS Microbiology Reviews, 015, pp. 549-574. doi: 10.1093/femsre/fux015. Increased in Alzheimer's Disease', Journal of Neurochemistry. Wiley-Blackwell, 68(5), pp. 2092 2097. doi: 10.1046/j.1471-4159.1997.68052092.x. 
30. Sigal, N., Pasechnek, A. and Herskovits, A. A. (2016) 'RNA purification from intracellularly grown listeria monocytogenes in macrophage cells', Journal of Visualized Experiments. Journal of Visualized Experiments, 2016(112). doi: 10.3791/54044.

31. Staerck, C. et al. (2017) 'Microbial antioxidant defense enzymes', Microbial Pathogenesis. Academic Press, pp. 56-65. doi: 10.1016/j.micpath.2017.06.015.

32. Stuehr, D. J. and Marletta, M. A. (1985) 'Mammalian nitrate biosynthesis: Mouse macrophages produce nitrite and nitrate in response to Escherichia coli lipopolysaccharide', Proceedings of the National Academy of Sciences of the United States of America, 82(22), pp. 7738-7742. doi: 10.1073/pnas.82.22.7738.

33. Uchida, K. (2003) '4-Hydroxy-2-nonenal: A product and mediator of oxidative stress', Progress in Lipid Research. Elsevier Ltd, pp. 318-343. doi: 10.1016/S0163-7827(03)00014-6.

34. Uchida, K. et al. (1994) 'Michael Addition-Type 4-Hydroxy-2-nonenal Adducts in Modified LowDensity Lipoproteins: Markers for Atherosclerosis', Biochemistry. American Chemical Society, 33(41), pp. 12487-12494. doi: 10.1021/bi00207a016.

35. Vaughn, S. F. and Gardner, H. W. (1993) 'Lipoxygenase-derived aldehydes inhibit fungi pathogenic on soybean', Journal of Chemical Ecology. Kluwer Academic Publishers-Plenum Publishers, 19(10), pp. 2337-2345. doi: 10.1007/BF00979668.

645

36. Yura, T., Nagai, H. and Mori, H. (1993) 'Regulation of the Heat-Shock Response in Bacteria', Annual Review of Microbiology. Annual Reviews, 47(1), pp. 321-350. doi: 10.1146/annurev.mi.47.100193.001541. 
37. Zhang, H. and Forman, H. J. (2017) 'Signaling by 4-hydroxy-2-nonenal: Exposure protocols, target selectivity and degradation', Archives of Biochemistry and Biophysics. Academic Press Inc., 617, pp.

652 145-154. doi: 10.1016/j.abb.2016.11.003.

653

654

38. Zheng, R. et al. (2014) 'Differential metabolism of 4-hydroxynonenal in liver, lung and brain of mice 655 and rats', Toxicology and Applied Pharmacology. Academic Press Inc., 279(1), pp. 43-52. doi:

656 10.1016/j.taap.2014.04.026.

657

658

39. Zimniak, P. (2011) 'Relationship of electrophilic stress to aging.', Free radical biology \& medicine.

NIH Public Access, 51(6), pp. 1087-105. doi: 10.1016/j.freeradbiomed.2011.05.039. 
Supplemental Fig 1.

A

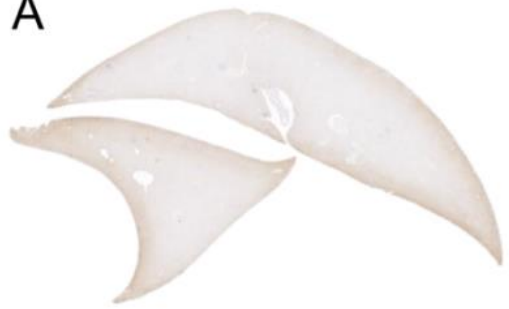

C

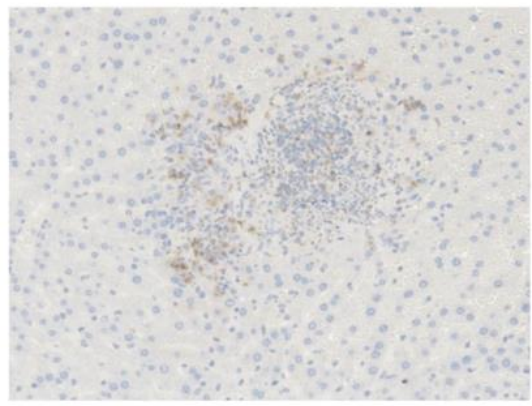

B

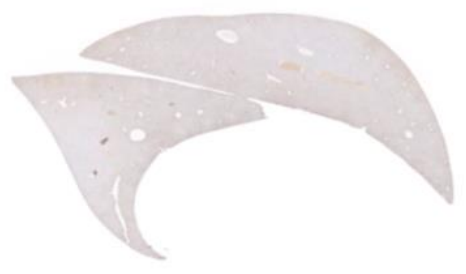

D

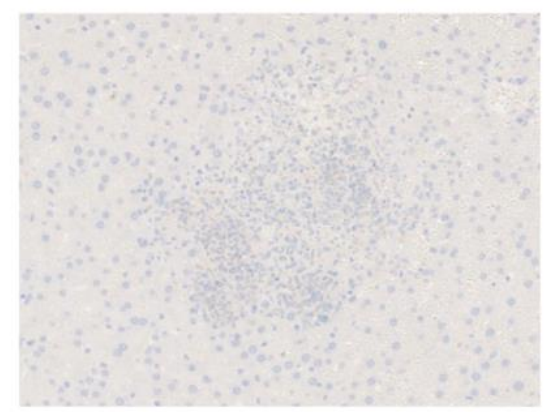

4-HNE accumulation in the liver during 48-hour murine infection by GFP + L. monocytogenes assessed by immunohistochemistry analysis.
A. Liver (infected) anti-4-HNE
B. Liver (uninfected) anti-4-HNE
C. Liver (infected) anti-GFP 10X magnification
D. Liver (infected) anti-HNE 10X magnification 

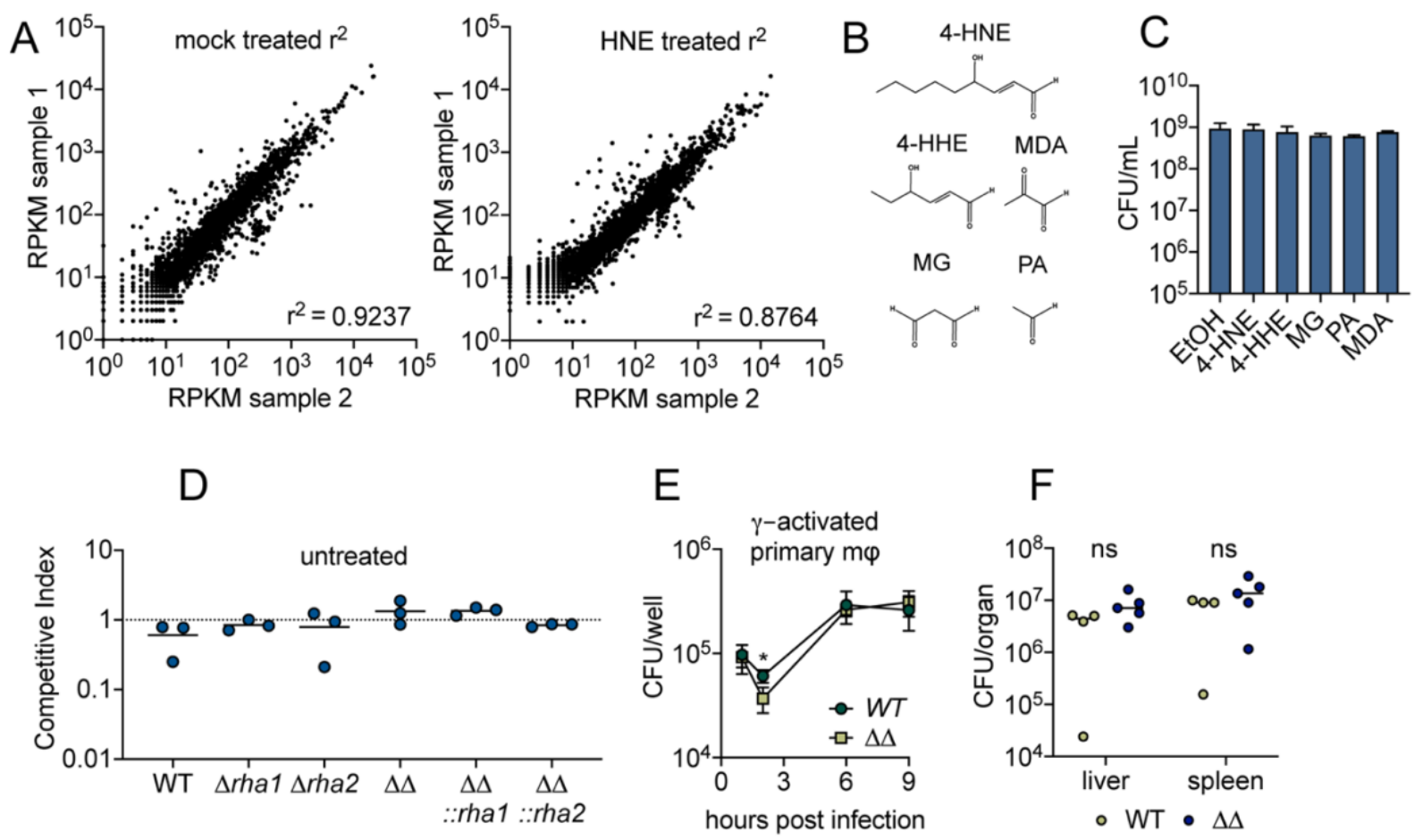

A. Global gene expression of midlog L. monocytogenes in TSB treated with ethanol mock control (panel 1) or $640 \mu \mathrm{M}$ 4-HNE (panel 1) for 20 minutes. RPKM: reads per kilobase million.

B. Aldehyde structures used in the experiment. 4-HNE: 4-hydroxy-2-nonenal, 4-HHE: 4-hydroxy-2hexenal, MDA: malondialdehyde, MG: methylglyoxal, PA: propionaldehyde

C. CFU post treatment with sublethal concentrations of listed aldehydes. Performed in technical duplicate.

D. Competitive index of 1 hour mock treated (ethanol) L. monocytogenes in PBS.

E. CFU/well of WT and $\Delta$ rha1 1 rha2 L. monocytogenes in 100ng recombinant murine IFN-Y activated WT primary murine macrophages. Performed in biological triplicate.

F. CFU/organ of WT and $\Delta r h a 1 \Delta r h a 2(\Delta \Delta)$ L. monocytogenes at 48 hours intravenous murine infection.

Statistics in (E) are unpaired t-tests comparing WT and $\Delta \Delta L$. monocytogenes CFU at hour 2 post infection. Statistics in $(F)$ are unpaired t-tests comparing $W T$ and $\Delta \Delta L$. monocytogenes CFU within each organ.

Error bars are mean +/- SD. ns $>0.05 ;{ }^{*}, p<0.05$. In figure $(F)$, the line is drawn at the median of data. 
A

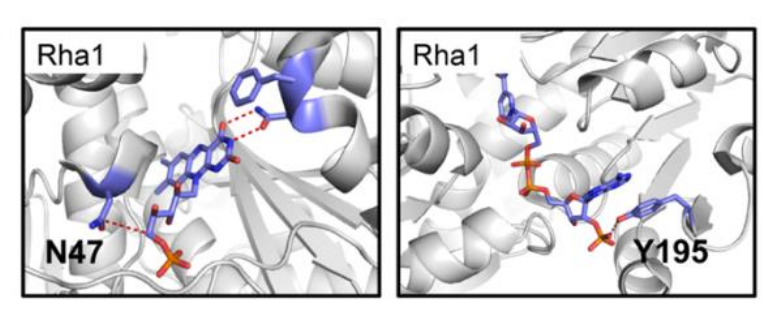

C
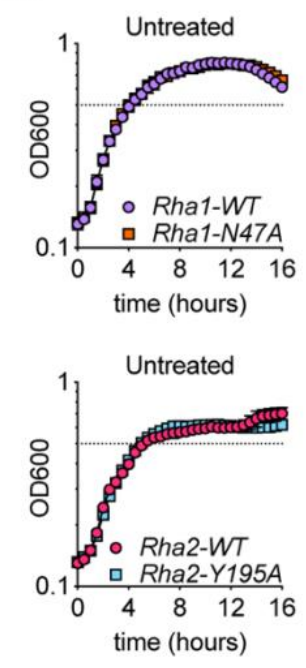
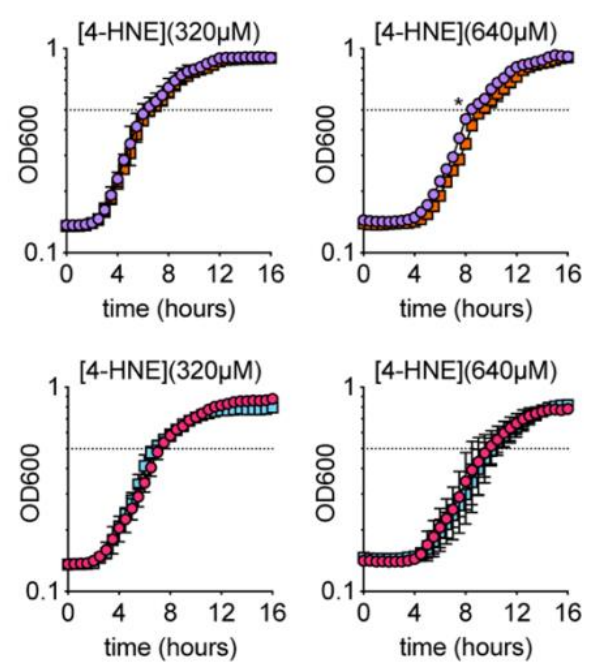
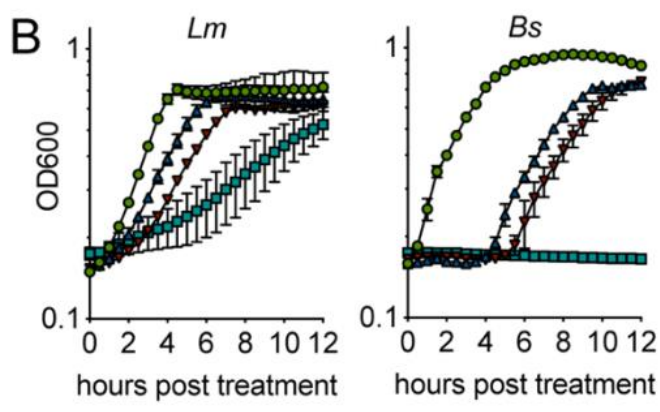
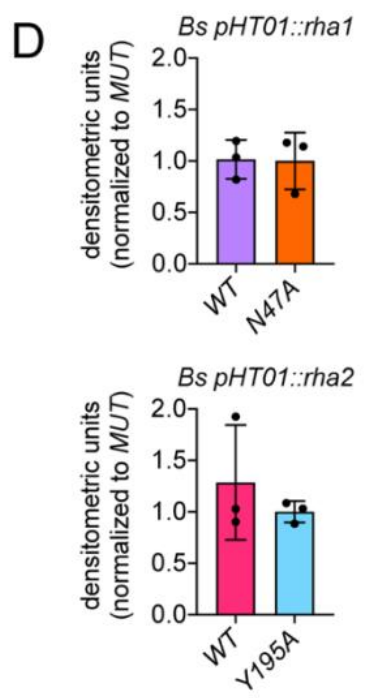

A. Modeling of Rha1 and Rha2 binding pockets with FMN (Rha1) and NADPH (Rha2) with corresponding predicted coordinating amino acid labeled. Coordinating amino acids are labeled. Blue indicates carbon, red indicates oxygen, orange indicates phosphorous. Rha1 is a predicted flavin containing reductase. In comparison between the structure of CLA-ER and the homology model of Rha1 predicted by Phyre2 analysis, several conserved residues lining the flavin binding pocket were identified and the N47A mutant was generated. Rha2 is a predicted NADPH reductase. Similar structural models were generated by Phyre2 analysis and a Y195A mutation in a conserved tyrosine residue predicted to be involved in NADPH co-substrate binding was generated. Figure generated in PyMol.

B. L. monocytogenes and B. subtilis growth curves in TSB after exposure to various concentrations of 4-HNE. (green circles: $0 \mu \mathrm{M}$, blue triangles: $320 \mu \mathrm{M}$, red triangles: $640 \mu \mathrm{M}$, light blue squares: $1280 \mu \mathrm{M}$ ). Data performed in technical duplicate and representative of at least three independent experiments.

C. Growth curves of B. subtilis:: pHT01 expressing various rha1 and rha2 constructs in TSB after exposure to various concentrations of 4-HNE. Dotted line represents OD 600 0.5. Performed in biological triplicate.

D. 4-HNE dot blots of B. subtilis:::pHT01 expressing various rha1 and rha2 constructs after 3 hours of exposure to $640 \mu \mathrm{M} 4-\mathrm{HNE}$ in TSB. Performed in biological triplicate.

Statistics in $(C)$ is an unpaired t-test comparing the hours to OD 0.5 between $B$. subtilis pHT01::rha1-WT and pHT01::rha1-N47A. Error bars are mean +/- SD. *, $p<0.05$. 
bioRxiv preprint doi: https://doi.org/10.1101/2020.05.25.115097; this version posted May 25, 2020. The copyright holder for this preprint (which was not certified by peer review) is the author/funder. All rights reserved. No reuse allowed without permission.

Supplemental Table 1

\begin{tabular}{|c|c|c|c|c|c|c|}
\hline \multicolumn{7}{|c|}{ Data presented here are sorted by q-value (statistical significance) $<0.05$} \\
\hline Synonym & Product & $\begin{array}{l}\text { Expression } \\
\text { mock }\end{array}$ & $\begin{array}{l}\text { Expression } \\
\text { HNE }\end{array}$ & $\begin{array}{l}\text { qValue wt vs } \\
\text { HNE }\end{array}$ & hne fold over mock & Imo numbers \\
\hline LMRG_00296 & oxidoreductase & 3 & 716 & 0 & 238.6666667 & $\operatorname{Imo0613}$ \\
\hline LMRG_00295 & hypothetical protein & 3 & 542 & 0 & 180.6666667 & $\operatorname{Imo0612}$ \\
\hline predicted RNA & antisense: LMRG_00484 & 15 & 2673 & 0 & 178.2 & \#N/A \\
\hline LMRG_00999 & mercuric ion binding protein & 2 & 332 & 0 & 166 & Imo1852 \\
\hline LMRG_01869 & hypothetical protein & 41 & 6735 & 0 & 164.2682927 & $\operatorname{Imo2829}$ \\
\hline LMRG_02304 & peptidoglycan bound protein & 1 & 137 & 0 & 137 & $\operatorname{Imo0880}$ \\
\hline predicted RNA & - & 19 & 2296 & 0 & 120.8421053 & \#N/A \\
\hline LMRG_00177 & hypothetical protein & 63 & 6244 & 0 & 99.11111111 & Imo0496 \\
\hline LMRG_02097 & $\begin{array}{l}\text { ATP-dependent Clp protease ATP-binding subunit } \\
\text { ClpE }\end{array}$ & 47 & 4494 & 0 & 95.61702128 & $\operatorname{Imo0997}$ \\
\hline LMRG_01000 & Cu2+-exporting ATPase & 33 & 2999 & 0 & 90.87878788 & Imo1853 \\
\hline LMRG_01001 & hypothetical protein & 18 & 1628 & 0 & 90.44444444 & Imo1854 \\
\hline LMRG_02351 & hypothetical protein & 3 & 260 & 0 & 86.66666667 & Imo0102 \\
\hline LMRG_00484 & Ycel like family protein & 75 & 5695 & 0 & 75.93333333 & Imo0796 \\
\hline LMRG_01602 & hypothetical protein & 30 & 1977 & 0 & 65.9 & Imo2230 \\
\hline predicted RNA & antisense: LMRG_02097 & 8 & 527 & 0 & 65.875 & $\# \mathrm{~N} / \mathrm{A}$ \\
\hline LMRG_02352 & hypothetical protein & 2 & 123 & 0 & 61.5 & $\operatorname{Imo0103}$ \\
\hline LMRG_00333 & hypothetical protein & 5 & 306 & 0 & 61.2 & Imo0646 \\
\hline predicted RNA & antisense: LMRG_01626 & 3 & 183 & 0 & 61 & $\# \mathrm{~N} / \mathrm{A}$ \\
\hline LMRG_01633 & OsmC/Ohr family protein & 12 & 668 & 0 & 55.66666667 & Imo2199 \\
\hline LMRG_02052 & hypothetical protein & 2 & 83 & 0 & 41.5 & Imo0953 \\
\hline LMRG_01632 & MarR family transcriptional regulator & 69 & 2700 & 0 & 39.13043478 & Imo2200 \\
\hline predicted RNA & antisense: LMRG_00177 & 6 & 226 & 0 & 37.66666667 & $\# \mathrm{~N} / \mathrm{A}$ \\
\hline LMRG_00482 & hypothetical protein & 19 & 714 & 0 & 37.57894737 & Imo0794 \\
\hline predicted RNA & - & 14 & 476 & 0 & 34 & $\# \mathrm{~N} / \mathrm{A}$ \\
\hline LMRG_02677 & CtsR family transcriptional regulator & 6 & 188 & 0 & 31.33333333 & Imo0229 \\
\hline predicted RNA & - & 8 & 244 & 0 & 30.5 & $\# \mathrm{~N} / \mathrm{A}$ \\
\hline LMRG_00129 & hypothetical protein & 8 & 239 & 0 & 29.875 & $\operatorname{lmo0437}$ \\
\hline LMRG_01948 & general stress protein 26 & 33 & 973 & 0 & 29.48484848 & $\operatorname{Imo2748}$ \\
\hline LMRG_00446 & hypothetical protein & 13 & 378 & 0 & 29.07692308 & $\operatorname{lmo0758}$ \\
\hline LMRG_02675 & ATP:guanido phosphotransferase & 12 & 344 & 0 & 28.66666667 & $\operatorname{Imo0231}$ \\
\hline LMRG_01674 & hypothetical protein & 59 & 1650 & 0 & 27.96610169 & Imo2158 \\
\hline LMRG_02676 & hypothetical protein & 12 & 319 & 0 & 26.58333333 & $\operatorname{Imo0230}$ \\
\hline LMRG_00581 & Clp protease & 51 & 1311 & 0 & 25.70588235 & $\operatorname{Imo1138}$ \\
\hline LMRG_00448 & hypothetical protein & 6 & 154 & 0 & 25.66666667 & $\operatorname{Imo0760}$ \\
\hline LMRG_00137 & hypothetical protein & 15 & 374 & 0 & 24.93333333 & $\operatorname{Imo0445}$ \\
\hline LMRG_02646 & internalin C2 & 6 & 140 & $1.17 \mathrm{E}-285$ & 23.33333333 & Imo0263 \\
\hline LMRG_00447 & glyoxylase & 4 & 92 & $1.91 \mathrm{E}-252$ & 23 & Imo0759 \\
\hline predicted RNA & - & 7 & 159 & $7.63 E-193$ & 22.71428571 & $\# \mathrm{~N} / \mathrm{A}$ \\
\hline LMRG_00583 & hypothetical protein & 16 & 344 & $1.04 \mathrm{E}-243$ & 21.5 & $\operatorname{Imo1140}$ \\
\hline LMRG_01626 & ATP-dependent chaperone ClpB & 80 & 1707 & $2.00 \mathrm{E}-230$ & 21.3375 & $\operatorname{Imo2206}$ \\
\hline
\end{tabular}


bioRxiv preprint doi: https://doi.org/10.1101/2020.05.25.115097; this version posted May 25, 2020. The copyright holder for this preprint (which was not certified by peer review) is the author/funder. All rights reserved. No reuse allowed without permission.

Supplemental Table 1

\begin{tabular}{|c|c|c|c|c|c|c|}
\hline LMRG_01029 & $30 \mathrm{~S}$ ribosomal protein $\mathrm{S} 14$ & 40 & 852 & $4.55 \mathrm{E}-255$ & 21.3 & $\operatorname{Imo1882}$ \\
\hline LMRG_01627 & phosphoglycerate mutase & 154 & 3240 & $4.37 \mathrm{E}-233$ & 21.03896104 & Imo2205 \\
\hline LMRG_00334 & hypothetical protein & 37 & 771 & $4.93 \mathrm{E}-241$ & 20.83783784 & Imo0647 \\
\hline LMRG_02768 & hypothetical protein & 4 & 83 & $9.40 \mathrm{E}-207$ & 20.75 & Imo1694 \\
\hline LMRG_01754 & phosphate transport system regulatory protein PhoU & 5 & 102 & $6.31 \mathrm{E}-187$ & 20.4 & Imo2494 \\
\hline LMRG_00489 & hypothetical protein & 14 & 276 & $4.94 \mathrm{E}-214$ & 19.71428571 & Imo0800 \\
\hline LMRG_02611 & succinyl-diaminopimelate desuccinylase & 6 & 117 & $2.33 \mathrm{E}-182$ & 19.5 & Imo0265 \\
\hline LMRG_01764 & membrane protein & 72 & 1388 & $3.23 E-219$ & 19.27777778 & Imo2484 \\
\hline LMRG_02736 & hypothetical protein & 9 & 171 & $3.09 E-199$ & 19 & $\operatorname{Imo2391}$ \\
\hline predicted RNA & - & 43 & 815 & $1.23 \mathrm{E}-167$ & 18.95348837 & \#N/A \\
\hline predicted RNA & antisense: LMRG_00335 & 22 & 414 & $7.52 \mathrm{E}-178$ & 18.81818182 & $\# \mathrm{~N} / \mathrm{A}$ \\
\hline LMRG_01219 & chaperonin GroS & 81 & 1484 & $4.17 \mathrm{E}-188$ & 18.32098765 & Imo2069 \\
\hline LMRG_02000 & dihydroxyacetone kinase & 4 & 72 & $1.49 \mathrm{E}-144$ & 18 & Imo2697 \\
\hline predicted RNA & antisense: LMRG_01296 & 13 & 233 & $1.77 \mathrm{E}-235$ & 17.92307692 & \#N/A \\
\hline LMRG_00285 & hypothetical protein & 6 & 107 & $2.64 \mathrm{E}-116$ & 17.83333333 & Imo0602 \\
\hline LMRG_00449 & hypothetical protein & 4 & 71 & $3.23 \mathrm{E}-110$ & 17.75 & $\operatorname{Imo0761}$ \\
\hline LMRG_02693 & CDF family cation efflux system protein & 22 & 389 & $1.54 \mathrm{E}-161$ & 17.68181818 & Imo2575 \\
\hline LMRG_02002 & dihydroxyacetone kinase DhaK subunit & 23 & 405 & $5.57 \mathrm{E}-165$ & 17.60869565 & Imo2695 \\
\hline predicted RNA & - & 14 & 241 & $9.22 \mathrm{E}-157$ & 17.21428571 & \#N/A \\
\hline LMRG_02674 & $\begin{array}{l}\text { ATP-dependent Clp protease ATP-binding subunit } \\
\text { ClpC }\end{array}$ & 37 & 626 & $9.91 \mathrm{E}-140$ & 16.91891892 & $\operatorname{Imo0232}$ \\
\hline LMRG_02808 & hypothetical protein & 7 & 118 & $2.54 \mathrm{E}-130$ & 16.85714286 & Imo2132 \\
\hline LMRG_02146 & Mg2+ transporter-C family protein & 16 & 269 & $5.53 E-139$ & 16.8125 & Imo2602 \\
\hline LMRG_02218 & universal stress protein & 12 & 201 & $1.25 \mathrm{E}-136$ & 16.75 & Imo2673 \\
\hline LMRG_00666 & hypothetical protein & 14 & 234 & $4.12 \mathrm{E}-137$ & 16.71428571 & Imo1220 \\
\hline LMRG_00293 & internalin & 6 & 100 & $2.29 \mathrm{E}-133$ & 16.66666667 & Imo0610 \\
\hline LMRG_00411 & pyruvate oxidase & 42 & 697 & $3.15 \mathrm{E}-148$ & 16.5952381 & Imo0722 \\
\hline LMRG_02697 & nicotinamidase & 24 & 398 & $8.74 \mathrm{E}-139$ & 16.58333333 & Imo2571 \\
\hline LMRG_02701 & hypothetical protein & 22 & 359 & $3.17 \mathrm{E}-133$ & 16.31818182 & Imo2567 \\
\hline LMRG_01972 & $\begin{array}{l}\text { DNA binding 3-demethylubiquinone-9 3- } \\
\text { methyltransferase domain-containing protein }\end{array}$ & 51 & 784 & $3.22 \mathrm{E}-127$ & 15.37254902 & Imo2724 \\
\hline predicted RNA & antisense: LMRG_02046 & 14 & 213 & $3.84 \mathrm{E}-177$ & 15.21428571 & $\# \mathrm{~N} / \mathrm{A}$ \\
\hline LMRG_01675 & hypothetical protein & 9 & 134 & $8.77 \mathrm{E}-110$ & 14.88888889 & $\operatorname{Imo2157}$ \\
\hline LMRG_00221 & tagatose 1,6-diphosphate aldolase & 183 & 2721 & $1.34 \mathrm{E}-99$ & 14.86885246 & Imo0539 \\
\hline LMRG_01814 & glutamate decarboxylase & 33 & 484 & $1.49 \mathrm{E}-147$ & 14.66666667 & Imo2434 \\
\hline LMRG_02001 & dihydroxyacetone kinase $L$ subunit & 16 & 233 & $1.17 \mathrm{E}-98$ & 14.5625 & Imo2696 \\
\hline predicted RNA & antisense: LMRG_02042 & 16 & 232 & $1.45 \mathrm{E}-174$ & 14.5 & $\# \mathrm{~N} / \mathrm{A}$ \\
\hline predicted RNA & antisense: LMRG_00221 & 15 & 214 & $9.08 \mathrm{E}-169$ & 14.26666667 & $\# \mathrm{~N} / \mathrm{A}$ \\
\hline LMRG_02003 & OsmC/Ohr family protein & 35 & 499 & $1.57 \mathrm{E}-103$ & 14.25714286 & Imo0903 \\
\hline predicted RNA & antisense: LMRG_00364 & 14 & 198 & $4.14 \mathrm{E}-134$ & 14.14285714 & $\# \mathrm{~N} / \mathrm{A}$ \\
\hline LMRG_01780 & Clp protease & 241 & 3361 & $2.53 \mathrm{E}-101$ & 13.94605809 & Imo2468 \\
\hline predicted RNA & antisense: LMRG_02779 & 31 & 431 & $8.30 \mathrm{E}-100$ & 13.90322581 & $\# \mathrm{~N} / \mathrm{A}$ \\
\hline LMRG_02382 & hypothetical protein & 5 & 67 & $1.75 \mathrm{E}-124$ & 13.4 & Imo0133 \\
\hline predicted RNA & - & 35 & 469 & $6.70 \mathrm{E}-92$ & 13.4 & $\# \mathrm{~N} / \mathrm{A}$ \\
\hline
\end{tabular}


bioRxiv preprint doi: https://doi.org/10.1101/2020.05.25.115097; this version posted May 25, 2020. The copyright holder for this preprint (which was not certified by peer review) is the author/funder. All rights reserved. No reuse allowed without permission.

Supplemental Table 1

\begin{tabular}{|c|c|c|c|c|c|c|}
\hline predicted RNA & antisense: LMRG_00073 & 15 & 199 & $1.12 \mathrm{E}-122$ & 13.26666667 & $\# \mathrm{~N} / \mathrm{A}$ \\
\hline predicted RNA & antisense: LMRG_00704 & 24 & 317 & $5.17 \mathrm{E}-154$ & 13.20833333 & $\# \mathrm{~N} / \mathrm{A}$ \\
\hline LMRG_00131 & hypothetical protein & 6 & 79 & $3.36 \mathrm{E}-70$ & 13.16666667 & Imo0439 \\
\hline LMRG_01236 & peptidoglycan binding protein & 16 & 207 & $4.29 \mathrm{E}-84$ & 12.9375 & Imo2085 \\
\hline LMRG_02633 & 50S ribosomal protein L25 Ctc-form & 13 & 167 & $3.18 \mathrm{E}-71$ & 12.84615385 & Imo0211 \\
\hline predicted RNA & antisense: LMRG_01869 & 23 & 295 & $1.89 \mathrm{E}-146$ & 12.82608696 & $\# \mathrm{~N} / \mathrm{A}$ \\
\hline predicted RNA & - & 37 & 465 & $4.87 \mathrm{E}-132$ & 12.56756757 & $\# \mathrm{~N} / \mathrm{A}$ \\
\hline LMRG_02472 & arginine deiminase & 42 & 527 & $1.70 \mathrm{E}-94$ & 12.54761905 & Imo0043 \\
\hline LMRG_00273 & hypothetical protein & 5 & 62 & $1.74 \mathrm{E}-56$ & 12.4 & $\operatorname{Imo0591}$ \\
\hline LMRG_01761 & hypothetical protein & 20 & 241 & $1.17 \mathrm{E}-69$ & 12.05 & Imo2487 \\
\hline LMRG_02147 & amidase & 10 & 120 & $3.25 \mathrm{E}-63$ & 12 & Imo2603 \\
\hline LMRG_01619 & hypothetical protein & 41 & 486 & $2.61 \mathrm{E}-69$ & 11.85365854 & Imo2213 \\
\hline LMRG_02290 & hypothetical protein & 46 & 514 & $4.62 \mathrm{E}-52$ & 11.17391304 & $\# \mathrm{~N} / \mathrm{A}$ \\
\hline LMRG_02036 & hypothetical protein & 7 & 77 & $1.99 \mathrm{E}-69$ & 11 & Imo0937 \\
\hline LMRG_02295 & hypothetical protein & 11 & 121 & $8.24 \mathrm{E}-51$ & 11 & Imo0871 \\
\hline LMRG_01753 & phosphate $\mathrm{ABC}$ transporter ATP-binding protein & 13 & 142 & $2.10 \mathrm{E}-50$ & 10.92307692 & Imo2495 \\
\hline predicted RNA & - & 36 & 390 & $1.30 \mathrm{E}-88$ & 10.83333333 & $\# \mathrm{~N} / \mathrm{A}$ \\
\hline predicted RNA & - & 23 & 247 & $1.02 \mathrm{E}-92$ & 10.73913043 & $\# \mathrm{~N} / \mathrm{A}$ \\
\hline LMRG_01763 & PspC domain-containing protein & 46 & 485 & $9.81 \mathrm{E}-47$ & 10.54347826 & Imo2485 \\
\hline predicted RNA & antisense: LMRG_00365 & 79 & 826 & $2.26 \mathrm{E}-45$ & 10.4556962 & $\# \mathrm{~N} / \mathrm{A}$ \\
\hline LMRG_02013 & succinate-semialdehyde dehydrogenase & 31 & 322 & $1.48 \mathrm{E}-65$ & 10.38709677 & Imo0913 \\
\hline LMRG_00341 & hypothetical protein & 81 & 831 & $1.21 \mathrm{E}-48$ & 10.25925926 & Imo0654 \\
\hline LMRG_02696 & $\begin{array}{l}\text { riboflavin biosynthesis protein RibD domain-containing } \\
\text { protein }\end{array}$ & 35 & 355 & $2.82 \mathrm{E}-47$ & 10.14285714 & Imo2572 \\
\hline LMRG_02695 & NADPH2:quinone reductase & 14 & 142 & $9.70 \mathrm{E}-42$ & 10.14285714 & Imo2573 \\
\hline LMRG_02247 & hypothetical protein & 113 & 1146 & $3.80 \mathrm{E}-61$ & 10.14159292 & Imo0822 \\
\hline LMRG_00272 & hypothetical protein & 16 & 158 & $4.99 \mathrm{E}-44$ & 9.875 & Imo0590 \\
\hline LMRG_02732 & hypothetical protein & 7 & 69 & $3.37 \mathrm{E}-37$ & 9.857142857 & Imo2387 \\
\hline LMRG_02398 & zinc transport system substrate-binding protein & 9 & 86 & $1.56 \mathrm{E}-31$ & 9.555555556 & Imo0153 \\
\hline predicted RNA & - & 30 & 285 & $1.62 \mathrm{E}-51$ & 9.5 & $\# \mathrm{~N} / \mathrm{A}$ \\
\hline LMRG_02094 & hypothetical protein & 8 & 76 & $1.20 \mathrm{E}-33$ & 9.5 & Imo0994 \\
\hline predicted RNA & antisense: LMRG_00288 & 29 & 266 & $1.50 \mathrm{E}-55$ & 9.172413793 & $\# \mathrm{~N} / \mathrm{A}$ \\
\hline LMRG_02622 & listeriolysin regulatory protein & 55 & 490 & $1.14 \mathrm{E}-42$ & 8.909090909 & Imo0200 \\
\hline predicted RNA & - & 128 & 1134 & $3.82 \mathrm{E}-31$ & 8.859375 & $\# \mathrm{~N} / \mathrm{A}$ \\
\hline LMRG_02011 & hypothetical protein & 24 & 211 & $4.50 \mathrm{E}-33$ & 8.791666667 & Imo0911 \\
\hline predicted RNA & - & 36 & 315 & $5.00 \mathrm{E}-29$ & 8.75 & $\# \mathrm{~N} / \mathrm{A}$ \\
\hline LMRG_02042 & hypothetical protein & 574 & 4865 & $2.49 \mathrm{E}-28$ & 8.475609756 & Imo0944 \\
\hline predicted RNA & - & 24 & 201 & $3.30 \mathrm{E}-25$ & 8.375 & $\# \mathrm{~N} / \mathrm{A}$ \\
\hline LMRG_01757 & hydrolase & 58 & 475 & $2.44 \mathrm{E}-33$ & 8.189655172 & Imo2491 \\
\hline LMRG_01153 & aryl-alcohol dehydrogenase & 11 & 90 & $2.59 \mathrm{E}-25$ & 8.181818182 & Imo2005 \\
\hline LMRG_01816 & hypothetical protein & 26 & 212 & $1.29 \mathrm{E}-25$ & 8.153846154 & Imo2432 \\
\hline LMRG_01353 & hypothetical protein & 15 & 120 & $9.60 \mathrm{E}-25$ & 8 & Imo1613 \\
\hline predicted RNA & - & 26 & 207 & $6.40 \mathrm{E}-37$ & 7.961538462 & $\# \mathrm{~N} / \mathrm{A}$ \\
\hline
\end{tabular}


bioRxiv preprint doi: https://doi.org/10.1101/2020.05.25.115097; this version posted May 25, 2020. The copyright holder for this preprint (which was not certified by peer review) is the author/funder. All rights reserved. No reuse allowed without permission.

Supplemental Table 1

\begin{tabular}{|c|c|c|c|c|c|c|}
\hline predicted RNA & antisense: LMRG_01149 & 29 & 229 & $1.18 \mathrm{E}-33$ & 7.896551724 & $\# \mathrm{~N} / \mathrm{A}$ \\
\hline LMRG_02734 & hypothetical protein & 58 & 456 & $1.24 \mathrm{E}-26$ & 7.862068966 & $\operatorname{Imo2389}$ \\
\hline predicted RNA & - & 36 & 277 & $1.50 \mathrm{E}-21$ & 7.694444444 & $\# \mathrm{~N} / \mathrm{A}$ \\
\hline LMRG_00897 & transcriptional regulator ZurR & 91 & 699 & $3.06 \mathrm{E}-30$ & 7.681318681 & Imo1445 \\
\hline LMRG_02476 & hypothetical protein & 17 & 130 & $3.36 \mathrm{E}-23$ & 7.647058824 & Imo0047 \\
\hline predicted RNA & - & 82 & 622 & $1.82 \mathrm{E}-21$ & 7.585365854 & $\# \mathrm{~N} / \mathrm{A}$ \\
\hline LMRG_02738 & hypothetical protein & 14 & 106 & $9.18 \mathrm{E}-22$ & 7.571428571 & Imo2393 \\
\hline LMRG_01680 & thioredoxin & 99 & 742 & $6.82 \mathrm{E}-26$ & 7.494949495 & Imo2152 \\
\hline predicted RNA & - & 104 & 778 & $4.76 \mathrm{E}-23$ & 7.480769231 & $\# \mathrm{~N} / \mathrm{A}$ \\
\hline LMRG_01444 & hypothetical protein & 111 & 823 & $2.31 \mathrm{E}-27$ & 7.414414414 & Im01526 \\
\hline LMRG_01755 & HTH-type transcriptional repressor czrA & 25 & 185 & $2.83 \mathrm{E}-19$ & 7.4 & $\operatorname{Imo2493}$ \\
\hline LMRG_02579 & hypothetical protein & 284 & 2051 & $5.97 \mathrm{E}-09$ & 7.221830986 & Imo0292 \\
\hline predicted RNA & antisense: LMRG_00364 & 33 & 235 & $8.76 \mathrm{E}-27$ & 7.121212121 & $\# \mathrm{~N} / \mathrm{A}$ \\
\hline LMRG_00357 & hypothetical protein & 10 & 71 & $8.56 \mathrm{E}-18$ & 7.1 & Imo0669 \\
\hline LMRG_02415 & hypothetical protein & 174 & 1233 & $2.19 \mathrm{E}-17$ & 7.086206897 & $\operatorname{Imo0170}$ \\
\hline predicted RNA & antisense: LMRG_02779 & 31 & 216 & $4.02 \mathrm{E}-31$ & 6.967741935 & $\# \mathrm{~N} / \mathrm{A}$ \\
\hline LMRG_01296 & zinc transport system substrate-binding protein & 339 & 2339 & $7.35 \mathrm{E}-14$ & 6.899705015 & Imo1671 \\
\hline LMRG_00928 & heat-inducible transcription repressor $\mathrm{HrcA}$ & 139 & 954 & $1.44 \mathrm{E}-19$ & 6.863309353 & Imo1475 \\
\hline LMRG_00292 & hypothetical protein & 38 & 259 & $2.51 \mathrm{E}-19$ & 6.815789474 & Imo0609 \\
\hline LMRG_01737 & sigma-54 modulation protein & 92 & 619 & $9.23 \mathrm{E}-23$ & 6.72826087 & Imo2511 \\
\hline LMRG_02884 & secreted protein & 18 & 121 & $4.42 \mathrm{E}-17$ & 6.722222222 & Imo0479 \\
\hline LMRG_00926 & chaperone DnaK & 276 & 1849 & $6.39 \mathrm{E}-07$ & 6.699275362 & Imo1473 \\
\hline LMRG_01028 & hypothetical protein & 81 & 537 & $1.75 \mathrm{E}-17$ & 6.62962963 & Imo1881 \\
\hline LMRG_02679 & hypothetical protein & 10 & 66 & $3.04 \mathrm{E}-17$ & 6.6 & Imo2588 \\
\hline predicted RNA & - & 31 & 202 & $2.61 \mathrm{E}-26$ & 6.516129032 & $\# \mathrm{~N} / \mathrm{A}$ \\
\hline LMRG_02215 & hypothetical protein & 14 & 91 & $4.97 \mathrm{E}-16$ & 6.5 & Imo2670 \\
\hline LMRG_02239 & hypothetical protein & 269 & 1736 & $1.84 \mathrm{E}-15$ & 6.453531599 & Imo2692 \\
\hline LMRG_02731 & hypothetical protein & 13 & 83 & $5.22 \mathrm{E}-14$ & 6.384615385 & Imo2386 \\
\hline LMRG_01140 & alpha-acetolactate decarboxylase & 347 & 2173 & $1.58 \mathrm{E}-12$ & 6.262247839 & Imo1992 \\
\hline LMRG_00521 & hypothetical protein & 17 & 106 & $2.08 \mathrm{E}-13$ & 6.235294118 & Imo1059 \\
\hline predicted RNA & - & 133 & 829 & $5.00 \mathrm{E}-14$ & 6.233082707 & $\# \mathrm{~N} / \mathrm{A}$ \\
\hline LMRG_00743 & glycerol-3-phosphate dehydrogenase & 32 & 198 & $5.21 \mathrm{E}-18$ & 6.1875 & Im01293 \\
\hline LMRG_01431 & glycerol uptake facilitator protein & 12 & 73 & $6.40 \mathrm{E}-12$ & 6.083333333 & $\operatorname{Im01539}$ \\
\hline predicted RNA & - & 56 & 340 & $7.37 \mathrm{E}-17$ & 6.071428571 & $\# \mathrm{~N} / \mathrm{A}$ \\
\hline LMRG_01762 & hypothetical protein & 31 & 188 & $2.63 \mathrm{E}-16$ & 6.064516129 & Imo2486 \\
\hline LMRG_01218 & chaperonin GroL & 281 & 1684 & $5.23 \mathrm{E}-06$ & 5.992882562 & Imo2068 \\
\hline LMRG_02694 & hypothetical protein & 241 & 1407 & $4.30 \mathrm{E}-14$ & 5.838174274 & Imo2574 \\
\hline LMRG_01756 & hypothetical protein & 338 & 1964 & $2.88 \mathrm{E}-13$ & 5.810650888 & Imo2492 \\
\hline predicted RNA & - & 168 & 971 & $2.98 \mathrm{E}-13$ & 5.779761905 & $\# \mathrm{~N} / \mathrm{A}$ \\
\hline LMRG_02700 & hypothetical protein & 14 & 80 & $2.05 \mathrm{E}-11$ & 5.714285714 & Imo2568 \\
\hline LMRG_01573 & hypothetical protein & 14 & 79 & $1.95 \mathrm{E}-09$ & 5.642857143 & Imo2258 \\
\hline LMRG_02331 & hypothetical protein & 24 & 133 & $3.16 \mathrm{E}-10$ & 5.541666667 & Imo0083 \\
\hline
\end{tabular}


bioRxiv preprint doi: https://doi.org/10.1101/2020.05.25.115097; this version posted May 25, 2020. The copyright holder for this preprint (which was not certified by peer review) is the author/funder. All rights reserved. No reuse allowed without permission.

Supplemental Table 1

\begin{tabular}{|c|c|c|c|c|c|c|}
\hline LMRG_00472 & mannose-specific PTS system IIA component & 21 & 116 & $1.38 \mathrm{E}-10$ & 5.523809524 & Imo0784 \\
\hline LMRG_01815 & tributyrin esterase & 120 & 658 & $1.48 \mathrm{E}-10$ & 5.483333333 & Imo2433 \\
\hline LMRG_00679 & thioredoxin & 104 & 569 & $2.18 \mathrm{E}-12$ & 5.471153846 & Imo1233 \\
\hline LMRG_02248 & aldo/keto reductase & 111 & 604 & $2.23 \mathrm{E}-10$ & 5.441441441 & Imo0823 \\
\hline LMRG_02813 & hypothetical protein & 13 & 70 & $3.75 \mathrm{E}-09$ & 5.384615385 & Imo1789 \\
\hline predicted RNA & antisense: LMRG_00288 & 144 & 768 & $7.93 \mathrm{E}-11$ & 5.333333333 & $\# \mathrm{~N} / \mathrm{A}$ \\
\hline LMRG_02609 & hypothetical protein & 25 & 131 & $1.77 \mathrm{E}-10$ & 5.24 & Imo0267 \\
\hline LMRG_02055 & $\mathrm{N}$-acetylglucosamine-6-phosphate deacetylase & 168 & 880 & 5.95E-09 & 5.238095238 & Imo0956 \\
\hline LMRG_01656 & hypothetical protein & 17 & 89 & $1.72 \mathrm{E}-09$ & 5.235294118 & Imo2176 \\
\hline LMRG_01794 & hypothetical protein & 13 & 68 & $9.42 \mathrm{E}-10$ & 5.230769231 & Imo2454 \\
\hline LMRG_02812 & MarR family transcriptional regulator & 39 & 202 & $6.79 \mathrm{E}-10$ & 5.179487179 & Imo1788 \\
\hline LMRG_01384 & thiol peroxidase & 43 & 222 & $4.11 \mathrm{E}-10$ & 5.162790698 & Imo1583 \\
\hline LMRG_00345 & endonuclease III & 13 & 66 & $1.24 \mathrm{E}-08$ & 5.076923077 & Imo0658 \\
\hline LMRG_00879 & osmoprotectant transport system permease & 43 & 218 & $2.60 \mathrm{E}-10$ & 5.069767442 & Imo1427 \\
\hline LMRG_02056 & glucosamine-6-phosphate isomerase & 59 & 299 & $8.90 \mathrm{E}-12$ & 5.06779661 & Imo0957 \\
\hline predicted RNA & antisense: LMRG_02397 & 80 & 403 & 8.77E-09 & 5.0375 & $\# \mathrm{~N} / \mathrm{A}$ \\
\hline LMRG_05029 & Met tRNA & 81 & 403 & $5.84 \mathrm{E}-09$ & 4.975308642 & $\# \mathrm{~N} / \mathrm{A}$ \\
\hline LMRG_00878 & $\begin{array}{l}\text { osmoprotectant transport system substrate-binding } \\
\text { protein }\end{array}$ & 79 & 391 & $4.62 \mathrm{E}-09$ & 4.949367089 & Imo1426 \\
\hline LMRG_01641 & arsenate reductase & 24 & 118 & $1.05 \mathrm{E}-07$ & 4.916666667 & Imo2191 \\
\hline LMRG_02054 & hypothetical protein & 50 & 243 & $8.38 \mathrm{E}-11$ & 4.86 & Imo0955 \\
\hline LMRG_01491 & HTH-type transcriptional regulator ytll & 27 & 131 & $1.45 \mathrm{E}-08$ & 4.851851852 & Imo2352 \\
\hline LMRG_01795 & hypothetical protein & 161 & 779 & $2.32 \mathrm{E}-08$ & 4.838509317 & Imo2453 \\
\hline predicted RNA & antisense: LMRG_02397 & 53 & 256 & $1.65 \mathrm{E}-08$ & 4.830188679 & $\# \mathrm{~N} / \mathrm{A}$ \\
\hline LMRG_01822 & arsenate reductase & 72 & 346 & $9.16 \mathrm{E}-09$ & 4.805555556 & Imo2426 \\
\hline predicted RNA & antisense: LMRG_01678 & 93 & 446 & $3.44 \mathrm{E}-08$ & 4.795698925 & $\# \mathrm{~N} / \mathrm{A}$ \\
\hline LMRG_00469 & mannose-specific PTS system IID component & 13 & 62 & $1.15 \mathrm{E}-08$ & 4.769230769 & Imo0781 \\
\hline LMRG_02397 & $\begin{array}{l}\text { peptide/nickel transport system substrate-binding } \\
\text { protein }\end{array}$ & 1002 & 4775 & 0.005247719 & 4.765469062 & Imo0152 \\
\hline LMRG_00488 & hypothetical protein & 107 & 509 & $3.27 \mathrm{E}-08$ & 4.757009346 & Imo0799 \\
\hline LMRG_00826 & peptidase T-like protein & 62 & 294 & $2.14 \mathrm{E}-08$ & 4.741935484 & Imo1375 \\
\hline LMRG_00877 & osmoprotectant transport system permease & 43 & 203 & $7.10 \mathrm{E}-09$ & 4.720930233 & Imo1425 \\
\hline predicted RNA & antisense: LMRG_01840 LMRG_01839 & 272 & 1280 & $5.55 \mathrm{E}-09$ & 4.705882353 & $\# \mathrm{~N} / \mathrm{A}$ \\
\hline LMRG_01066 & hypothetical protein & 73 & 340 & $3.46 \mathrm{E}-10$ & 4.657534247 & Imo1919 \\
\hline LMRG_01679 & ribonucleotide reductase-associated flavodoxin & 204 & 949 & $1.84 \mathrm{E}-07$ & 4.651960784 & Imo2153 \\
\hline LMRG_00470 & mannose-specific PTS system IIC component & 43 & 200 & 7.17E-09 & 4.651162791 & Imo0782 \\
\hline LMRG_00294 & FMN-dependent NADH-azoreductase 1 & 24 & 111 & $2.83 \mathrm{E}-07$ & 4.625 & Imo0611 \\
\hline LMRG_01469 & hypothetical protein & 95 & 436 & $2.53 \mathrm{E}-08$ & 4.589473684 & Imo1501 \\
\hline LMRG_00132 & hypothetical protein & 50 & 227 & $1.15 \mathrm{E}-07$ & 4.54 & $\operatorname{Imo0440}$ \\
\hline LMRG_00925 & chaperone DnaJ & 105 & 471 & $3.15 \mathrm{E}-07$ & 4.485714286 & Imo1472 \\
\hline LMRG_02764 & hypothetical protein & 228 & 1021 & $2.47 \mathrm{E}-06$ & 4.478070175 & Imo1690 \\
\hline LMRG_01207 & protoheme IX farnesyltransferase & 15 & 67 & $1.93 \mathrm{E}-06$ & 4.466666667 & Imo2057 \\
\hline LMRG_01068 & hypothetical protein & 24 & 107 & $3.84 \mathrm{E}-07$ & 4.458333333 & Imo1921 \\
\hline predicted RNA & - & 47 & 209 & $2.45 \mathrm{E}-11$ & 4.446808511 & $\# \mathrm{~N} / \mathrm{A}$ \\
\hline
\end{tabular}


bioRxiv preprint doi: https://doi.org/10.1101/2020.05.25.115097; this version posted May 25, 2020. The copyright holder for this preprint (which was not certified by peer review) is the author/funder. All rights reserved. No reuse allowed without permission.

Supplemental Table 1

\begin{tabular}{|c|c|c|c|c|c|c|}
\hline LMRG_00885 & glutathione reductase & 18 & 80 & $1.03 \mathrm{E}-06$ & 4.444444444 & Imo1433 \\
\hline LMRG_02076 & hypothetical protein & 18 & 80 & $3.98 \mathrm{E}-06$ & 4.444444444 & Imo0976 \\
\hline LMRG_00290 & $\mathrm{ABC}$ transporter & 70 & 311 & $4.35 \mathrm{E}-07$ & 4.442857143 & Imo0607 \\
\hline predicted RNA & antisense: LMRG_01556 & 60 & 266 & $2.64 \mathrm{E}-06$ & 4.433333333 & $\# \mathrm{~N} / \mathrm{A}$ \\
\hline LMRG_01154 & acetolactate synthase catabolic & 85 & 376 & $2.83 \mathrm{E}-07$ & 4.423529412 & Imo2006 \\
\hline LMRG_00927 & co-chaperone GrpE & 74 & 326 & $9.01 \mathrm{E}-09$ & 4.405405405 & Imo1474 \\
\hline LMRG_02350 & hypothetical protein & 164 & 704 & $9.58 \mathrm{E}-09$ & 4.292682927 & Imo0101 \\
\hline LMRG_02320 & sigma-B negative regulator & 24 & 103 & $2.85 \mathrm{E}-06$ & 4.291666667 & Imo0896 \\
\hline LMRG_00836 & hypothetical protein & 207 & 885 & $8.45 \mathrm{E}-06$ & 4.275362319 & Imo1384 \\
\hline LMRG_00880 & osmoprotectant transport system ATP-binding protein & 62 & 264 & $2.14 \mathrm{E}-06$ & 4.258064516 & Imo1428 \\
\hline predicted RNA & antisense: LMRG_02384 & 72 & 306 & $6.76 \mathrm{E}-06$ & 4.25 & $\# \mathrm{~N} / \mathrm{A}$ \\
\hline predicted RNA & - & 42 & 177 & $2.49 \mathrm{E}-09$ & 4.214285714 & \#N/A \\
\hline LMRG_02053 & hypothetical protein & 32 & 133 & $8.57 \mathrm{E}-06$ & 4.15625 & Imo0954 \\
\hline LMRG_02666 & ribonuclease III family protein & 25 & 103 & $1.17 \mathrm{E}-05$ & 4.12 & Imo0240 \\
\hline predicted RNA & antisense: LMRG_02397 & 54 & 221 & $7.03 \mathrm{E}-06$ & 4.092592593 & $\# \mathrm{~N} / \mathrm{A}$ \\
\hline LMRG_00891 & superoxide dismutase & 110 & 450 & $2.97 \mathrm{E}-06$ & 4.090909091 & Imo1439 \\
\hline LMRG_00289 & transcription regulator MarR family protein & 183 & 748 & $8.08 \mathrm{E}-06$ & 4.087431694 & Imo0606 \\
\hline LMRG_02216 & hypothetical protein & 16 & 65 & $2.31 \mathrm{E}-05$ & 4.0625 & Imo2671 \\
\hline LMRG_01690 & hypothetical protein & 34 & 138 & $2.03 \mathrm{E}-06$ & 4.058823529 & Imo2557 \\
\hline LMRG_01850 & phosphatidylglycerophosphatase $\mathrm{A}$ & 76 & 307 & $9.10 \mathrm{E}-07$ & 4.039473684 & Imo2398 \\
\hline LMRG_02758 & hypothetical protein & 26 & 105 & $9.71 \mathrm{E}-06$ & 4.038461538 & Imo1684 \\
\hline LMRG_02845 & GntR family transcriptional regulator & 34 & 137 & $6.75 \mathrm{E}-06$ & 4.029411765 & Imo0902 \\
\hline LMRG_00291 & $\mathrm{ABC}$ transporter & 152 & 610 & $1.44 \mathrm{E}-04$ & 4.013157895 & Imo0608 \\
\hline LMRG_02414 & sugar uptake protein & 28 & 112 & $1.18 \mathrm{E}-05$ & 4 & Imo0169 \\
\hline predicted RNA & antisense: LMRG_05509 & 42 & 167 & $3.33 \mathrm{E}-06$ & 3.976190476 & $\# \mathrm{~N} / \mathrm{A}$ \\
\hline LMRG_01770 & thioredoxin-disulfide reductase & 90 & 356 & $2.26 \mathrm{E}-05$ & 3.955555556 & Imo2478 \\
\hline LMRG_02869 & mannose-specific PTS system IIB component & 17 & 67 & $8.85 \mathrm{E}-05$ & 3.941176471 & Imo0783 \\
\hline predicted RNA & antisense: LMRG_05515 & 42 & 165 & $5.69 \mathrm{E}-06$ & 3.928571429 & \#N/A \\
\hline LMRG_00261 & hypothetical protein & 56 & 220 & $1.95 \mathrm{E}-05$ & 3.928571429 & Imo0579 \\
\hline LMRG_01851 & thioredoxin-like protein & 23 & 89 & $1.88 \mathrm{E}-05$ & 3.869565217 & Imo2397 \\
\hline LMRG_01678 & ribonucleoside-diphosphate reductase & 617 & 2371 & 0.039824699 & 3.842787682 & Imo2154 \\
\hline LMRG_02667 & cysteinyl-tRNA synthetase & 54 & 207 & $3.60 \mathrm{E}-05$ & 3.833333333 & Imo0239 \\
\hline LMRG_02665 & TrmH family RNA methyltransferase group 3 & 63 & 241 & $1.51 \mathrm{E}-06$ & 3.825396825 & Imo0241 \\
\hline LMRG_00884 & hypothetical protein & 337 & 1276 & $2.19 \mathrm{E}-04$ & 3.786350148 & Imo1432 \\
\hline LMRG_02082 & deblocking aminopeptidase & 22 & 83 & $5.76 \mathrm{E}-05$ & 3.772727273 & Imo0982 \\
\hline LMRG_00266 & hypothetical protein & 135 & 508 & $5.74 \mathrm{E}-05$ & 3.762962963 & Imo0584 \\
\hline LMRG_00707 & hypothetical protein & 54 & 203 & $2.40 \mathrm{E}-06$ & 3.759259259 & Imo1258 \\
\hline predicted RNA & antisense: LMRG_02771 & 49 & 184 & $7.32 \mathrm{E}-08$ & 3.755102041 & $\# \mathrm{~N} / \mathrm{A}$ \\
\hline LMRG_00032 & hypothetical protein & 27 & 101 & $1.99 \mathrm{E}-04$ & 3.740740741 & Imo0341 \\
\hline LMRG_05008 & Arg tRNA & 50 & 187 & $1.45 \mathrm{E}-04$ & 3.74 & $\# \mathrm{~N} / \mathrm{A}$ \\
\hline LMRG_00898 & zinc transport system permease & 61 & 228 & $1.63 \mathrm{E}-05$ & 3.737704918 & Imo1446 \\
\hline LMRG_02663 & RNA polymerase sporulation-specific sigma factor & 181 & 673 & $1.27 \mathrm{E}-04$ & 3.718232044 & $\operatorname{Imo0243}$ \\
\hline
\end{tabular}


bioRxiv preprint doi: https://doi.org/10.1101/2020.05.25.115097; this version posted May 25, 2020. The copyright holder for this preprint (which was not certified by peer review) is the author/funder. All rights reserved. No reuse allowed without permission.

Supplemental Table 1

\begin{tabular}{|c|c|c|c|c|c|c|}
\hline LMRG_01937 & hypothetical protein & 21 & 78 & $9.21 \mathrm{E}-05$ & 3.714285714 & Imo2759 \\
\hline LMRG_00278 & hypothetical protein & 78 & 289 & $7.49 \mathrm{E}-06$ & 3.705128205 & Imo0596 \\
\hline LMRG_02786 & carbonic anhydrase & 33 & 122 & $8.27 \mathrm{E}-05$ & 3.696969697 & Imo0811 \\
\hline LMRG_01114 & hypothetical protein & 153 & 558 & $3.50 \mathrm{E}-04$ & 3.647058824 & Imo1967 \\
\hline LMRG_01297 & hypothetical protein & 117 & 425 & $5.59 \mathrm{E}-05$ & 3.632478632 & Imo1670 \\
\hline predicted RNA & antisense: LMRG_00515 LMRG_00514 & 119 & 430 & $1.75 \mathrm{E}-04$ & 3.613445378 & $\# \mathrm{~N} / \mathrm{A}$ \\
\hline LMRG_01870 & hypothetical protein & 53 & 190 & $2.12 \mathrm{E}-04$ & 3.58490566 & Imo2828 \\
\hline LMRG_00337 & membrane protein & 31 & 111 & $2.04 \mathrm{E}-04$ & 3.580645161 & $\operatorname{Imo0650}$ \\
\hline LMRG_02349 & hypothetical protein & 169 & 605 & $6.05 \mathrm{E}-05$ & 3.579881657 & $\operatorname{Imo0100}$ \\
\hline LMRG_00753 & cell division suppressor protein yneA & 19 & 68 & $5.66 \mathrm{E}-04$ & 3.578947368 & Imo1303 \\
\hline LMRG_00745 & host factor-I protein & 243 & 867 & $5.76 \mathrm{E}-05$ & 3.567901235 & Imo1295 \\
\hline LMRG_02959 & multidrug resistance protein & 37 & 131 & $1.00 \mathrm{E}-05$ & 3.540540541 & Imo1712 \\
\hline predicted RNA & antisense: LMRG_01609 & 75 & 262 & $5.43 \mathrm{E}-04$ & 3.493333333 & $\# \mathrm{~N} / \mathrm{A}$ \\
\hline LMRG_00835 & isopentenyl-diphosphate delta-isomerase type 2 & 292 & 1019 & 0.002406516 & 3.489726027 & Imo1383 \\
\hline LMRG_02063 & hypothetical protein & 70 & 244 & $1.20 \mathrm{E}-04$ & 3.485714286 & Imo0964 \\
\hline LMRG_02317 & anti-sigma-B factor antagonist & 77 & 267 & $1.85 \mathrm{E}-04$ & 3.467532468 & Imo0893 \\
\hline LMRG_00354 & antibiotic transport system ATP-binding protein & 82 & 282 & $4.34 \mathrm{E}-04$ & 3.43902439 & Imo0667 \\
\hline LMRG_00899 & zinc uptake system ATP-binding protein zurA & 55 & 189 & $3.94 \mathrm{E}-05$ & 3.436363636 & Imo1447 \\
\hline LMRG_01823 & glycine cleavage system $\mathrm{H}$ protein & 37 & 127 & $4.03 \mathrm{E}-04$ & 3.432432432 & Imo2425 \\
\hline LMRG_02050 & hypothetical protein & 38 & 130 & $2.17 \mathrm{E}-04$ & 3.421052632 & Imo0951 \\
\hline LMRG_01811 & hypothetical protein & 56 & 191 & $4.20 \mathrm{E}-04$ & 3.410714286 & Imo2437 \\
\hline LMRG_00258 & hypothetical protein & 18 & 61 & $3.96 \mathrm{E}-04$ & 3.388888889 & Imo0576 \\
\hline LMRG_02643 & type III pantothenate kinase & 149 & 504 & $5.73 \mathrm{E}-04$ & 3.382550336 & Imo0221 \\
\hline LMRG_02644 & chaperonin $\mathrm{HsIO}$ & 41 & 138 & $1.68 \mathrm{E}-04$ & 3.365853659 & Imo0222 \\
\hline LMRG_01556 & gp27 & 114 & 383 & $4.07 \mathrm{E}-04$ & 3.359649123 & \#N/A \\
\hline LMRG_02714 & general stress protein 13 & 143 & 480 & $6.94 \mathrm{E}-05$ & 3.356643357 & Imo2369 \\
\hline LMRG_01615 & hypothetical protein & 87 & 292 & $3.01 \mathrm{E}-04$ & 3.356321839 & Imo2217 \\
\hline LMRG_02735 & hypothetical protein & 159 & 527 & $7.10 \mathrm{E}-04$ & 3.314465409 & Imo2390 \\
\hline LMRG_02445 & cytochrome aa3 quinol oxidase subunit IV & 31 & 102 & 0.00194844 & 3.290322581 & Imo0016 \\
\hline LMRG_00520 & hypothetical protein & 58 & 190 & 0.001066446 & 3.275862069 & Imo1058 \\
\hline LMRG_01365 & hypothetical protein & 81 & 265 & $2.92 \mathrm{E}-04$ & 3.271604938 & Imo1602 \\
\hline predicted RNA & antisense: LMRG_02224 & 73 & 238 & 0.001730138 & 3.260273973 & $\# \mathrm{~N} / \mathrm{A}$ \\
\hline LMRG_01796 & carboxylesterase & 47 & 153 & $4.39 \mathrm{E}-04$ & 3.255319149 & Imo2452 \\
\hline predicted RNA & antisense: LMRG_05511 & 75 & 244 & 0.001100033 & 3.253333333 & \#N/A \\
\hline LMRG_01357 & thioredoxin-like protein ytpP & 29 & 93 & 0.003804507 & 3.206896552 & Imo1609 \\
\hline LMRG_02718 & cellobiose-specific PTS system IIB component & 31 & 99 & 0.002545682 & 3.193548387 & Imo2373 \\
\hline LMRG_00235 & hypothetical protein & 410 & 1307 & 0.006174283 & 3.187804878 & Imo0553 \\
\hline LMRG_02293 & hypothetical protein & 22 & 70 & 0.001841892 & 3.181818182 & Imo0869 \\
\hline predicted RNA & antisense: LMRG_02834 & 111 & 353 & 0.001722101 & 3.18018018 & $\# \mathrm{~N} / \mathrm{A}$ \\
\hline LMRG_02245 & hypothetical protein & 29 & 92 & 0.001924661 & 3.172413793 & Imo0820 \\
\hline LMRG_05032 & Arg tRNA & 58 & 184 & 0.002078209 & 3.172413793 & $\# \mathrm{~N} / \mathrm{A}$ \\
\hline predicted RNA & antisense: LMRG_01571 & 112 & 355 & 0.001936706 & 3.169642857 & $\# N / A$ \\
\hline
\end{tabular}


bioRxiv preprint doi: https://doi.org/10.1101/2020.05.25.115097; this version posted May 25, 2020. The copyright holder for this preprint (which was not certified by peer review) is the author/funder. All rights reserved. No reuse allowed without permission.

Supplemental Table 1

\begin{tabular}{|c|c|c|c|c|c|c|}
\hline LMRG_00103 & pyruvate,water dikinase & 25 & 79 & 0.001765837 & 3.16 & Imo0410 \\
\hline LMRG_02041 & starvation-inducible DNA-binding protein & 846 & 2651 & 0.029780284 & 3.13356974 & Imo0943 \\
\hline LMRG_01113 & hypothetical protein & 94 & 293 & 0.001053115 & 3.117021277 & Imo1966 \\
\hline LMRG_02007 & hypothetical protein & 83 & 258 & 0.001066446 & 3.108433735 & Imo0907 \\
\hline LMRG_02057 & GntR family transcriptional regulator & 48 & 149 & 0.001066276 & 3.104166667 & Imo0958 \\
\hline LMRG_02610 & hypothetical protein & 31 & 96 & 0.002731204 & 3.096774194 & Imo0266 \\
\hline LMRG_01575 & protease I & 32 & 99 & 0.002100988 & 3.09375 & Imo2256 \\
\hline LMRG_02263 & MarR family transcriptional regulator & 32 & 99 & 0.002865296 & 3.09375 & Imo0840 \\
\hline LMRG_01833 & FeS assembly ATPase SufC & 278 & 857 & 0.006208014 & 3.082733813 & Imo2415 \\
\hline LMRG_02437 & diamine $\mathrm{N}$-acetyltransferase & 33 & 101 & 0.002572121 & 3.060606061 & Imo0009 \\
\hline LMRG_02792 & hypothetical protein & 76 & 231 & 0.001558446 & 3.039473684 & $\# \mathrm{~N} / \mathrm{A}$ \\
\hline predicted RNA & - & 73 & 220 & 0.00451781 & 3.01369863 & $\# \mathrm{~N} / \mathrm{A}$ \\
\hline LMRG_02375 & hypothetical protein & 33 & 99 & 0.004438201 & 3 & Imo0126 \\
\hline LMRG_00417 & hypothetical protein & 45 & 133 & 0.004725323 & 2.955555556 & Imo0729 \\
\hline LMRG_01568 & hypothetical protein & 42 & 124 & 0.002673939 & 2.952380952 & Imo2263 \\
\hline predicted RNA & - & 88 & 256 & 0.005176832 & 2.909090909 & $\# \mathrm{~N} / \mathrm{A}$ \\
\hline LMRG_02343 & hypothetical protein & 21 & 61 & 0.008216044 & 2.904761905 & Imo0094 \\
\hline predicted RNA & - & 82 & 236 & 0.003455037 & 2.87804878 & $\# \mathrm{~N} / \mathrm{A}$ \\
\hline LMRG_02077 & hypothetical protein & 37 & 106 & 0.00581421 & 2.864864865 & Imo0977 \\
\hline LMRG_02938 & serine O-acetyltransferase & 22 & 63 & 0.013315824 & 2.863636364 & Imo0238 \\
\hline predicted RNA & antisense: LMRG_00233 & 117 & 333 & 0.008711523 & 2.846153846 & $\# \mathrm{~N} / \mathrm{A}$ \\
\hline LMRG_01576 & hypothetical protein & 37 & 105 & 0.017136024 & 2.837837838 & Imo2255 \\
\hline LMRG_01402 & DNA polymerase I & 55 & 156 & 0.005065534 & 2.836363636 & Imo1565 \\
\hline LMRG_02117 & PTS system glucose-specific transporter subunit IIA & 82 & 230 & 0.0032698 & 2.804878049 & Imo1017 \\
\hline LMRG_00080 & hypothetical protein & 209 & 584 & 0.010165448 & 2.794258373 & Imo0387 \\
\hline LMRG_02274 & hypothetical protein & 99 & 275 & 0.010550408 & 2.777777778 & Imo0851 \\
\hline LMRG_01777 & NADPH dehydrogenase & 31 & 86 & 0.006728628 & 2.774193548 & Imo2471 \\
\hline predicted RNA & antisense: LMRG_05504 & 63 & 174 & 0.018568862 & 2.761904762 & \#N/A \\
\hline LMRG_02089 & hypothetical protein & 57 & 157 & 0.013197896 & 2.754385965 & Imo0989 \\
\hline LMRG_00336 & hypothetical protein & 23 & 63 & 0.025737754 & 2.739130435 & Imo0649 \\
\hline predicted RNA & antisense: LMRG_05508 & 87 & 237 & 0.012951781 & 2.724137931 & $\# \mathrm{~N} / \mathrm{A}$ \\
\hline LMRG_00236 & hypothetical protein & 89 & 242 & 0.018535735 & 2.719101124 & Imo0554 \\
\hline LMRG_02259 & hypothetical protein & 109 & 295 & 0.003559122 & 2.706422018 & Imo0836 \\
\hline LMRG_00512 & polypeptide deformylase & 243 & 649 & 0.008885988 & 2.670781893 & Imo1051 \\
\hline LMRG_00081 & hypothetical protein & 48 & 128 & 0.018674629 & 2.666666667 & Imo0388 \\
\hline LMRG_00173 & transcription regulator LysR & 29 & 77 & 0.018961544 & 2.655172414 & Imo0492 \\
\hline LMRG_01007 & peptide-methionine (S)-S-oxide reductase & 482 & 1278 & 0.041761156 & 2.651452282 & Imo1860 \\
\hline predicted RNA & antisense: LMRG_05517 & 97 & 257 & 0.014391515 & 2.649484536 & $\# \mathrm{~N} / \mathrm{A}$ \\
\hline predicted RNA & antisense: LMRG_00479 & 94 & 248 & 0.023529652 & 2.638297872 & $\# \mathrm{~N} / \mathrm{A}$ \\
\hline LMRG_02673 & DNA repair protein RadA & 41 & 108 & 0.010760569 & 2.634146341 & Imo0233 \\
\hline LMRG_01624 & hypothetical protein & 63 & 165 & 0.005014105 & 2.619047619 & Imo2208 \\
\hline LMRG_00519 & L-lactate dehydrogenase & 79 & 206 & 0.021438437 & 2.607594937 & Imo1057 \\
\hline
\end{tabular}


bioRxiv preprint doi: https://doi.org/10.1101/2020.05.25.115097; this version posted May 25, 2020. The copyright holder for this preprint (which was not certified by peer review) is the author/funder. All rights reserved. No reuse allowed without permission.

Supplemental Table 1

\begin{tabular}{|c|c|c|c|c|c|c|}
\hline LMRG_00458 & transcriptional regulator & 25 & 65 & 0.018961544 & 2.6 & Imo0770 \\
\hline LMRG_01623 & hypothetical protein & 25 & 65 & 0.021265447 & 2.6 & Imo2209 \\
\hline LMRG_01403 & formamidopyrimidine-DNA glycosylase & 34 & 88 & 0.021453834 & 2.588235294 & Imo1564 \\
\hline predicted RNA & antisense: LMRG_05505 & 123 & 317 & 0.025246604 & 2.577235772 & $\# \mathrm{~N} / \mathrm{A}$ \\
\hline LMRG_00701 & hypothetical protein & 178 & 457 & 0.02523123 & 2.56741573 & $\# \mathrm{~N} / \mathrm{A}$ \\
\hline LMRG_02615 & HlyD family secretion protein & 39 & 100 & 0.021634833 & 2.564102564 & Imo0193 \\
\hline predicted RNA & antisense: LMRG_05514 & 96 & 245 & 0.03036087 & 2.552083333 & \#N/A \\
\hline LMRG_01055 & hypothetical protein & 42 & 107 & 0.043428349 & 2.547619048 & Imo1908 \\
\hline predicted RNA & antisense: LMRG_00554 & 67 & 170 & $8.34 \mathrm{E}-04$ & 2.537313433 & $\# \mathrm{~N} / \mathrm{A}$ \\
\hline LMRG_02244 & hypothetical protein & 89 & 225 & 0.030493736 & 2.528089888 & Imo0819 \\
\hline LMRG_01069 & hypothetical protein & 42 & 106 & 0.01320132 & 2.523809524 & Imo1922 \\
\hline LMRG_00205 & hypothetical protein & 48 & 121 & 0.033431119 & 2.520833333 & Imo0524 \\
\hline LMRG_00090 & hypothetical protein & 52 & 131 & 0.032359701 & 2.519230769 & Imo0397 \\
\hline LMRG_00442 & hypothetical protein & 54 & 136 & 0.019786837 & 2.518518519 & Imo0754 \\
\hline LMRG_02037 & protein-tyrosine phosphatase & 157 & 392 & 0.033431119 & 2.496815287 & Imo0938 \\
\hline predicted RNA & - & 238 & 591 & 0.026337976 & 2.483193277 & $\# \mathrm{~N} / \mathrm{A}$ \\
\hline LMRG_02386 & peptide/nickel transport system permease & 146 & 362 & 0.020624817 & 2.479452055 & Imo0137 \\
\hline LMRG_02635 & peptidyl-tRNA hydrolase & 54 & 131 & 0.039822953 & 2.425925926 & $\operatorname{Imo0213}$ \\
\hline LMRG_00280 & transcription regulator CRP/FNR family protein & 26 & 63 & 0.044916888 & 2.423076923 & Imo0597 \\
\hline LMRG_01847 & hydrolase & 43 & 104 & 0.032798066 & 2.418604651 & Imo2401 \\
\hline LMRG_01856 & transcriptional regulator & 46 & 111 & 0.016880131 & 2.413043478 & Imo2842 \\
\hline LMRG_01036 & hypothetical protein & 107 & 255 & 0.033198142 & 2.38317757 & Imo1889 \\
\hline LMRG_01051 & hypothetical protein & 47 & 112 & 0.020005519 & 2.382978723 & Imo1904 \\
\hline LMRG_02049 & hypothetical protein & 134 & 319 & 0.044879257 & 2.380597015 & Imo0950 \\
\hline LMRG_02946 & hypothetical protein & 252 & 595 & 0.021633399 & 2.361111111 & $\# \mathrm{~N} / \mathrm{A}$ \\
\hline LMRG_02108 & hypothetical protein & 252 & 586 & 0.041761156 & 2.325396825 & Imo1008 \\
\hline LMRG_00452 & lipoate-protein ligase $\mathrm{A}$ & 37 & 86 & 0.038929387 & 2.324324324 & Imo0764 \\
\hline LMRG_01834 & FeS assembly protein SufD & 118 & 273 & 0.042967549 & 2.313559322 & Imo2414 \\
\hline LMRG_01047 & aspartate 1-decarboxylase & 341 & 784 & 0.044283805 & 2.299120235 & Imo1900 \\
\hline LMRG_01054 & dihydrodipicolinate reductase & 64 & 147 & 0.02980491 & 2.296875 & Imo1907 \\
\hline LMRG_02444 & cytochrome aa3 quinol oxidase subunit III & 64 & 145 & 0.038929387 & 2.265625 & Imo0015 \\
\hline predicted RNA & - & 353 & 799 & 0.04803035 & 2.263456091 & $\# \mathrm{~N} / \mathrm{A}$ \\
\hline LMRG_01210 & hypothetical protein & 76 & 169 & 0.035520736 & 2.223684211 & Imo2060 \\
\hline LMRG_02727 & multicomponent $\mathrm{Na}+\mathrm{H}+$ antiporter subunit $\mathrm{E}$ & 124 & 63 & 0.032125345 & 0.508064516 & Imo2382 \\
\hline LMRG_02008 & hypothetical protein & 65 & 33 & 0.020005519 & 0.507692308 & Imo0908 \\
\hline LMRG_01700 & homoserine dehydrogenase & 201 & 101 & 0.047175323 & 0.502487562 & Imo2547 \\
\hline LMRG_02800 & sodium transport system permease & 48 & 24 & 0.035658352 & 0.5 & Imo2140 \\
\hline LMRG_02585 & aminotransferase & 52 & 26 & 0.038929387 & 0.5 & Imo0286 \\
\hline LMRG_02250 & hydroxymethylglutaryl-CoA reductase & 48 & 24 & 0.03981199 & 0.5 & Imo0825 \\
\hline LMRG_00681 & aspartate kinase & 182 & 91 & 0.040562131 & 0.5 & Imo1235 \\
\hline LMRG_02620 & $\begin{array}{l}\text { UDP-N-acetylglucosamine } \\
\text { diphosphorylase/glucosamine-1-phosphate N- } \\
\text { acetyltransferase }\end{array}$ & 130 & 65 & 0.04364084 & 0.5 & $\operatorname{Imo0198}$ \\
\hline LMRG_01394 & $\begin{array}{l}\text { acetyl-CoA carboxylase carboxyl transferase subunit } \\
\text { beta }\end{array}$ & 48 & 24 & 0.044283805 & 0.5 & Imo1573 \\
\hline
\end{tabular}


bioRxiv preprint doi: https://doi.org/10.1101/2020.05.25.115097; this version posted May 25, 2020. The copyright holder for this preprint (which was not certified by peer review) is the author/funder. All rights reserved. No reuse allowed without permission.

Supplemental Table 1

\begin{tabular}{|c|c|c|c|c|c|c|}
\hline LMRG_02124 & hypothetical protein & 44 & 22 & 0.047789583 & 0.5 & Imo1024 \\
\hline LMRG_02312 & hypothetical protein & 283 & 141 & 0.04803035 & 0.498233216 & Imo0888 \\
\hline LMRG_00784 & secreted protein & 257 & 128 & 0.04215241 & 0.498054475 & Imo1334 \\
\hline LMRG_00413 & hypothetical protein & 350 & 173 & 0.039495623 & 0.494285714 & Imo0724 \\
\hline LMRG_01002 & D-alanyl-D-alanine carboxypeptidase & 81 & 40 & 0.023124458 & 0.49382716 & Imo1855 \\
\hline predicted RNA & - & 1606 & 790 & 0.033748261 & 0.491905355 & $\# \mathrm{~N} / \mathrm{A}$ \\
\hline LMRG_02641 & tRNA(Ile)-lysidine synthetase & 147 & 72 & 0.03871668 & 0.489795918 & $\operatorname{Imo0219}$ \\
\hline LMRG_01347 & D-amino acid aminotransferase & 333 & 163 & 0.03990536 & 0.489489489 & $\operatorname{Imo1619}$ \\
\hline LMRG_00908 & hypothetical protein & 190 & 93 & 0.002408231 & 0.489473684 & Imo1456 \\
\hline LMRG_00995 & manganese transport system membrane protein $\mathrm{mntC}$ & 178 & 87 & 0.029152211 & 0.488764045 & Imo1848 \\
\hline LMRG_00537 & teichoic acids export ATP-binding protein tagH & 84 & 41 & 0.020653577 & 0.488095238 & Imo1075 \\
\hline LMRG_02621 & ribose-phosphate pyrophosphokinase 1 & 355 & 173 & 0.038289935 & 0.487323944 & Imo0199 \\
\hline LMRG_01143 & deoxyribose-phosphate aldolase & 142 & 69 & 0.037493838 & 0.485915493 & Imo1995 \\
\hline LMRG_00883 & hypothetical protein & 266 & 129 & 0.041730146 & 0.484962406 & Imo1431 \\
\hline LMRG_02502 & phosphoribosylformylglycinamidine synthase II & 31 & 15 & 0.021382699 & 0.483870968 & Imo1769 \\
\hline LMRG_02167 & $30 \mathrm{~S}$ ribosomal protein $\mathrm{S} 17$ & 461 & 223 & 0.034746604 & 0.48373102 & Imo2623 \\
\hline LMRG_01773 & phosphoglucomutase/phosphomannomutase & 54 & 26 & 0.03885516 & 0.481481481 & Imo2475 \\
\hline LMRG_01892 & hypothetical protein & 52 & 25 & 0.016954793 & 0.480769231 & Imo2804 \\
\hline LMRG_00993 & multidrug resistance protein norM & 50 & 24 & 0.015638073 & 0.48 & Imo1846 \\
\hline LMRG_00685 & $\begin{array}{l}\text { rdgB/HAM1 family non-canonical purine NTP } \\
\text { pyrophosphatase }\end{array}$ & 221 & 106 & 0.026237749 & 0.479638009 & $\operatorname{Imo1239}$ \\
\hline predicted RNA & - & 1672 & 800 & 0.013365301 & 0.4784689 & $\# \mathrm{~N} / \mathrm{A}$ \\
\hline LMRG_01697 & hypothetical protein & 46 & 22 & 0.034356578 & 0.47826087 & Imo2550 \\
\hline LMRG_02180 & 1,4-dihydroxy-2-naphthoate octaprenyltransferase & 67 & 32 & 0.018674629 & 0.47761194 & Imo2635 \\
\hline LMRG_02684 & response regulator & 74 & 35 & 0.023677106 & 0.472972973 & Imo2583 \\
\hline LMRG_02879 & hypothetical protein & 55 & 26 & 0.009199536 & 0.472727273 & Imo0528 \\
\hline LMRG_01168 & isoleucyl-tRNA synthetase & 70 & 33 & $5.73 \mathrm{E}-04$ & 0.471428571 & Imo2019 \\
\hline LMRG_00536 & teichoic acid transport system permease & 51 & 24 & 0.029891732 & 0.470588235 & Imo1074 \\
\hline LMRG_00965 & ribulose-phosphate 3-epimerase & 149 & 70 & 0.026728806 & 0.469798658 & Imo1818 \\
\hline LMRG_02252 & pyruvate:ferredoxin oxidoreductase & 66 & 31 & 0.026347347 & 0.46969697 & Imo0829 \\
\hline LMRG_01406 & replication initiation and membrane attachment protein & 330 & 155 & 0.035630534 & 0.46969697 & Imo1561 \\
\hline LMRG_01374 & NifS/icsS protein & 49 & 23 & 0.013354675 & 0.469387755 & Imo1593 \\
\hline predicted RNA & - & 868 & 406 & 0.020408525 & 0.467741935 & $\# \mathrm{~N} / \mathrm{A}$ \\
\hline LMRG_00211 & $\mathrm{N}$-acetylglucosaminyltransferase & 30 & 14 & 0.044813253 & 0.466666667 & Imo0529 \\
\hline LMRG_00281 & biotin biosynthesis protein BioY & 133 & 62 & 0.010993339 & 0.466165414 & \#N/A \\
\hline LMRG_01793 & phosphopyruvate hydratase & 1243 & 579 & 0.02779667 & 0.465808528 & Imo2455 \\
\hline LMRG_00301 & hypothetical protein & 41 & 19 & 0.021453834 & 0.463414634 & Imo0618 \\
\hline LMRG_01330 & ABC transporter ATP-binding protein & 237 & 109 & 0.021382699 & 0.459915612 & Imo1636 \\
\hline LMRG_01284 & hypothetical protein & 192 & 88 & 0.023052624 & 0.458333333 & Imo2130 \\
\hline LMRG_01373 & septation ring formation regulator EzrA & 313 & 143 & 0.030958788 & 0.45686901 & Imo1594 \\
\hline LMRG_00905 & hypothetical protein & 125 & 57 & 0.007034615 & 0.456 & Imo1453 \\
\hline LMRG_01063 & beta-lactamase & 145 & 66 & 0.015455111 & 0.455172414 & Imo1916 \\
\hline LMRG_01685 & hypothetical protein & 33 & 15 & 0.047803696 & 0.454545455 & $\operatorname{Imo2147}$ \\
\hline
\end{tabular}


bioRxiv preprint doi: https://doi.org/10.1101/2020.05.25.115097; this version posted May 25, 2020. The copyright holder for this preprint (which was not certified by peer review) is the author/funder. All rights reserved. No reuse allowed without permission.

Supplemental Table 1

\begin{tabular}{|c|c|c|c|c|c|c|}
\hline LMRG_00758 & hypothetical protein & 97 & 44 & 0.008216044 & 0.453608247 & Imo1308 \\
\hline LMRG_00703 & alpha-phosphotrehalase & 181 & 82 & 0.02165941 & 0.453038674 & Imo1254 \\
\hline LMRG_02699 & $\begin{array}{l}\text { peptide/nickel transport system substrate-binding } \\
\text { protein }\end{array}$ & 371 & 168 & 0.032359701 & 0.452830189 & Imo2569 \\
\hline LMRG_02168 & 50S ribosomal protein L29 & 349 & 158 & 0.009456532 & 0.452722063 & Imo2624 \\
\hline LMRG_02150 & DNA-directed RNA polymerase subunit alpha & 685 & 310 & 0.045972061 & 0.452554745 & Imo2606 \\
\hline LMRG_00952 & ribonuclease III & 250 & 113 & 0.011835797 & 0.452 & Imo1805 \\
\hline LMRG_01062 & malate dehydrogenase & 113 & 51 & 0.014960466 & 0.451327434 & Imo1915 \\
\hline LMRG_02185 & heptaprenyl diphosphate synthase component I & 246 & 111 & 0.018334167 & 0.451219512 & Imo2640 \\
\hline LMRG_00534 & pyruvate carboxylase & 404 & 182 & 0.038260918 & 0.45049505 & Imo1072 \\
\hline LMRG_00961 & hypothetical protein & 60 & 27 & 0.014081458 & 0.45 & Imo1814 \\
\hline LMRG_02820 & hypothetical protein & 145 & 65 & 0.0383802 & 0.448275862 & Imo1796 \\
\hline predicted RNA & antisense: LMRG_02657 & 654 & 293 & 0.03871668 & 0.448012232 & \#N/A \\
\hline LMRG_01034 & N6-adenine-specific DNA methylase & 76 & 34 & 0.005810536 & 0.447368421 & Imo1887 \\
\hline LMRG_02656 & large subunit ribosomal protein $\mathrm{L} 10$ & 1275 & 569 & 0.032743346 & 0.44627451 & Imo0250 \\
\hline LMRG_01253 & glutamine amidotransferase subunit pdxT & 299 & 133 & 0.009044345 & 0.444816054 & Imo2102 \\
\hline LMRG_00941 & nicotinate nucleotide adenylyltransferase & 135 & 60 & 0.006294116 & 0.444444444 & Imo1488 \\
\hline LMRG_00765 & di-trans,poly-cis-decaprenylcistransferase & 187 & 83 & 0.013134209 & 0.443850267 & Imo1315 \\
\hline LMRG_02051 & hypothetical protein & 210 & 93 & 0.006922704 & 0.442857143 & Imo0952 \\
\hline LMRG_02360 & hypothetical protein & 113 & 50 & 0.004666342 & 0.442477876 & Imo0111 \\
\hline LMRG_02181 & thiamine biosynthesis lipoprotein & 118 & 52 & 0.016805534 & 0.440677966 & Imo2636 \\
\hline LMRG_02599 & hypothetical protein & 66 & 29 & 0.007640077 & 0.439393939 & Imo0276 \\
\hline LMRG_02177 & $30 \mathrm{~S}$ ribosomal protein $\mathrm{S} 10$ & 746 & 327 & 0.013197896 & 0.438337802 & Imo2633 \\
\hline LMRG_02712 & glucose-6-phosphate isomerase & 963 & 422 & 0.037643237 & 0.438213915 & Imo2367 \\
\hline LMRG_02088 & peptide chain release factor 3 & 176 & 77 & 0.013046027 & 0.4375 & Imo0988 \\
\hline LMRG_01408 & threonyl-tRNA synthetase & 112 & 49 & 0.015305858 & 0.4375 & Imo1559 \\
\hline LMRG_02432 & hypothetical protein & 117 & 51 & 0.031589071 & 0.435897436 & Imo0004 \\
\hline LMRG_00802 & hypothetical protein & 590 & 254 & 0.006832118 & 0.430508475 & $\operatorname{Imo1352}$ \\
\hline LMRG_00550 & hypothetical protein & 135 & 58 & 0.007061656 & 0.42962963 & Imo1088 \\
\hline LMRG_00147 & hypothetical protein & 35 & 15 & 0.004337716 & 0.428571429 & Imo0455 \\
\hline LMRG_02348 & hypothetical protein & 138 & 59 & 0.004955323 & 0.427536232 & Imo0099 \\
\hline LMRG_00771 & hypothetical protein & 134 & 57 & 0.004312974 & 0.425373134 & Imo1321 \\
\hline LMRG_02278 & D-alanine--D-alanine ligase & 146 & 62 & 0.005807016 & 0.424657534 & Imo0855 \\
\hline LMRG_01638 & peptide/nickel transport system permease & 721 & 305 & 0.04919203 & 0.423023578 & Imo2194 \\
\hline LMRG_02501 & phosphoribosylformylglycinamidine synthase I & 31 & 13 & 0.049232295 & 0.419354839 & Imo1770 \\
\hline LMRG_05006 & Gly tRNA & 5433 & 2278 & 0.010459305 & 0.419289527 & $\# \mathrm{~N} / \mathrm{A}$ \\
\hline LMRG_01772 & aldose 1-epimerase & 456 & 191 & 0.010762338 & 0.418859649 & Imo2476 \\
\hline LMRG_00744 & tRNA delta(2)-isopentenylpyrophosphate transferase & 203 & 85 & 0.004477661 & 0.418719212 & Imo1294 \\
\hline LMRG_00944 & ribosome biogenesis GTPase $\mathrm{YqeH}$ & 696 & 291 & 0.049164568 & 0.418103448 & Imo1491 \\
\hline LMRG_01303 & methionine adenosyltransferase & 137 & 57 & 0.004283812 & 0.416058394 & Imo1664 \\
\hline LMRG_01473 & uridine kinase & 41 & 17 & 0.04301591 & 0.414634146 & Imo1497 \\
\hline LMRG_01360 & DNA segregation ATPase FtsK/SpollIE & 152 & 63 & 0.010095766 & 0.414473684 & Imo1606 \\
\hline LMRG_00704 & trehalose-specific PTS system IIBC component & 162 & 67 & 0.0063181 & 0.413580247 & Imo1255 \\
\hline
\end{tabular}


bioRxiv preprint doi: https://doi.org/10.1101/2020.05.25.115097; this version posted May 25, 2020. The copyright holder for this preprint (which was not certified by peer review) is the author/funder. All rights reserved. No reuse allowed without permission.

Supplemental Table 1

\begin{tabular}{|c|c|c|c|c|c|c|}
\hline LMRG_01038 & recombination protein $U$ & 179 & 74 & 0.005263869 & 0.413407821 & $\operatorname{Imo1891}$ \\
\hline LMRG_00275 & formate/nitrite transporter & 119 & 49 & 0.001306163 & 0.411764706 & Imo0593 \\
\hline LMRG_02176 & $50 \mathrm{~S}$ ribosomal protein L3 & 506 & 207 & 0.006832118 & 0.409090909 & Imo2632 \\
\hline LMRG_00870 & nucleotide pyrophosphatase & 93 & 38 & 0.008061528 & 0.408602151 & Imo1418 \\
\hline LMRG_00966 & ribosome small subunit-dependent GTPase $\mathrm{A}$ & 142 & 58 & 0.008512739 & 0.408450704 & Imo1819 \\
\hline LMRG_00901 & endonuclease 4 & 130 & 53 & 0.006954465 & 0.407692308 & Imo1449 \\
\hline LMRG_01124 & ribonuclease Z & 32 & 13 & 0.030716609 & 0.40625 & Imo1977 \\
\hline predicted RNA & antisense: LMRG_01720 & 160 & 65 & 0.04102053 & 0.40625 & $\# \mathrm{~N} / \mathrm{A}$ \\
\hline LMRG_00674 & ribonuclease HIII & 32 & 13 & 0.043051938 & 0.40625 & $\operatorname{Im01228}$ \\
\hline LMRG_02280 & alpha/beta fold family hydrolase & 106 & 43 & 0.001883725 & 0.405660377 & Imo0857 \\
\hline LMRG_05034 & Gly tRNA & 4718 & 1889 & 0.005916195 & 0.400381518 & $\# \mathrm{~N} / \mathrm{A}$ \\
\hline LMRG_01084 & ribosome-associated GTPase EngA & 200 & 80 & 0.004192147 & 0.4 & Imo1937 \\
\hline LMRG_00954 & 3-oxoacyl-ACP reductase & 45 & 18 & 0.014038157 & 0.4 & Imo1807 \\
\hline LMRG_01714 & F-type $\mathrm{H}+$-transporting ATPase subunit C & 484 & 193 & 0.001306163 & 0.398760331 & Imo2534 \\
\hline LMRG_00529 & GTP-binding protein TypA/BipA & 224 & 89 & 0.006238853 & 0.397321429 & Imo1067 \\
\hline LMRG_01169 & cell division initiation protein & 68 & 27 & 0.014408909 & 0.397058824 & Imo2020 \\
\hline LMRG_01582 & PiT family inorganic phosphate transporter & 754 & 298 & 0.017102841 & 0.395225464 & Imo2249 \\
\hline LMRG_00773 & hypothetical protein & 947 & 373 & 0.003406903 & 0.393875396 & Imo1323 \\
\hline LMRG_02271 & polar amino acid transport system ATP-binding protein & 112 & 44 & 0.001070677 & 0.392857143 & Imo0848 \\
\hline LMRG_00832 & hypothetical protein & 396 & 155 & 0.001640079 & 0.391414141 & Imo1380 \\
\hline LMRG_00318 & 2-haloalkanoic acid dehalogenase & 296 & 114 & 0.002014978 & 0.385135135 & Imo0635 \\
\hline LMRG_02770 & hypothetical protein & 65 & 25 & 0.007034615 & 0.384615385 & Imo1696 \\
\hline LMRG_01926 & antibiotic transport system ATP-binding protein & 39 & 15 & 0.012232232 & 0.384615385 & Imo2769 \\
\hline LMRG_01340 & hypothetical protein & 136 & 52 & 0.001194099 & 0.382352941 & Imo1626 \\
\hline LMRG_05045 & Lys tRNA & 1810 & 690 & 0.00345001 & 0.38121547 & $\# \mathrm{~N} / \mathrm{A}$ \\
\hline LMRG_01099 & diaminopimelate decarboxylase & 108 & 41 & 0.002777291 & 0.37962963 & Imo1952 \\
\hline LMRG_01079 & trans-hexaprenyltranstransferase & 467 & 177 & 0.002933682 & 0.379014989 & Imo1932 \\
\hline LMRG_01090 & hypothetical protein & 45 & 17 & 0.005014008 & 0.377777778 & Imo1943 \\
\hline LMRG_02586 & $\begin{array}{l}\text { D-methionine transport system substrate-binding } \\
\text { protein }\end{array}$ & 398 & 150 & 0.002200451 & 0.376884422 & Imo0285 \\
\hline LMRG_02315 & serine/threonine-protein kinase rsbT & 146 & 55 & $7.89 \mathrm{E}-04$ & 0.376712329 & Imo0891 \\
\hline LMRG_02119 & hypothetical protein & 77 & 29 & $6.28 \mathrm{E}-04$ & 0.376623377 & Imo1019 \\
\hline LMRG_00657 & integral membrane protein & 40 & 15 & 0.036269745 & 0.375 & Imo1211 \\
\hline LMRG_02175 & $50 \mathrm{~S}$ ribosomal protein $\mathrm{L} 4 / \mathrm{L} 1$ & 884 & 331 & 0.002853719 & 0.374434389 & Imo2631 \\
\hline LMRG_01243 & glycine betaine transporter & 59 & 22 & $3.96 \mathrm{E}-04$ & 0.372881356 & Imo2092 \\
\hline LMRG_00419 & hypothetical protein & 43 & 16 & 0.039856044 & 0.372093023 & Imo0731 \\
\hline LMRG_01363 & peroxiredoxin & 250 & 93 & 0.002708912 & 0.372 & Imo1604 \\
\hline LMRG_01792 & $\begin{array}{l}\text { 2,3-bisphosphoglycerate-independent } \\
\text { phosphoglycerate mutase }\end{array}$ & 1390 & 517 & 0.002493673 & 0.371942446 & Imo2456 \\
\hline LMRG_00812 & exodeoxyribonuclease VII small subunit & 119 & 44 & 0.012379762 & 0.369747899 & Imo1362 \\
\hline LMRG_00612 & threonine-phosphate decarboxylase & 38 & 14 & 0.00563131 & 0.368421053 & Imo1169 \\
\hline LMRG_05036 & Lys tRNA & 3699 & 1354 & 0.001375696 & 0.366044877 & $\# \mathrm{~N} / \mathrm{A}$ \\
\hline LMRG_01414 & delta-aminolevulinic acid dehydratase & 41 & 15 & 0.004441472 & 0.365853659 & Imo1554 \\
\hline predicted RNA & antisense: LMRG_01081 & 707 & 257 & 0.006238853 & 0.363507779 & $\# \mathrm{~N} / \mathrm{A}$ \\
\hline
\end{tabular}


bioRxiv preprint doi: https://doi.org/10.1101/2020.05.25.115097; this version posted May 25, 2020. The copyright holder for this preprint (which was not certified by peer review) is the author/funder. All rights reserved. No reuse allowed without permission.

Supplemental Table 1

\begin{tabular}{|c|c|c|c|c|c|c|}
\hline LMRG_00392 & hypothetical protein & 295 & 107 & 0.0016435 & 0.362711864 & Imo0703 \\
\hline LMRG_02759 & glutamate-1-semialdehyde 2,1-aminomutase 2 & 91 & 33 & $5.05 \mathrm{E}-04$ & 0.362637363 & Imo1685 \\
\hline LMRG_01412 & porphobilinogen deaminase & 50 & 18 & 0.002877714 & 0.36 & Imo1556 \\
\hline predicted RNA & - & 225 & 81 & 0.011560716 & 0.36 & \#N/A \\
\hline LMRG_02744 & multiple sugar transport system permease & 53 & 19 & 0.002233874 & 0.358490566 & Imo0179 \\
\hline LMRG_02784 & fructokinase & 90 & 32 & $1.69 \mathrm{E}-04$ & 0.355555556 & Imo0813 \\
\hline LMRG_01443 & bifunctional preprotein translocase subunit SecD/SecF & 249 & 88 & 0.001306163 & 0.353413655 & Imo1527 \\
\hline predicted RNA & - & 2015 & 710 & $3.40 \mathrm{E}-04$ & 0.35235732 & $\# \mathrm{~N} / \mathrm{A}$ \\
\hline predicted RNA & - & 375 & 132 & $4.83 \mathrm{E}-05$ & 0.352 & \#N/A \\
\hline LMRG_01141 & pyrimidine-nucleoside phosphorylase & 37 & 13 & 0.002721735 & 0.351351351 & Imo1993 \\
\hline LMRG_01033 & carboxypeptidase Taq & 180 & 63 & $8.59 \mathrm{E}-04$ & 0.35 & Imo1886 \\
\hline LMRG_01717 & ATP synthase F1 alpha subunit & 277 & 96 & $9.11 \mathrm{E}-04$ & 0.346570397 & Imo2531 \\
\hline LMRG_00171 & shikimate 5-dehydrogenase & 52 & 18 & 0.002151164 & 0.346153846 & Imo0490 \\
\hline LMRG_01691 & fructose-16-bisphosphate aldolase class II & 2798 & 968 & 0.001156859 & 0.345961401 & Imo2556 \\
\hline LMRG_01630 & 3-oxoacyl-ACP synthase & 67 & 23 & $2.92 \mathrm{E}-04$ & 0.343283582 & Imo2202 \\
\hline LMRG_01696 & transcription termination factor Rho & 35 & 12 & 0.001999326 & 0.342857143 & Imo2551 \\
\hline LMRG_01097 & segregation and condensation protein $B$ & 794 & 272 & $7.23 \mathrm{E}-04$ & 0.34256927 & Imo1950 \\
\hline LMRG_01425 & septum site-determining protein minC & 38 & 13 & 0.006680086 & 0.342105263 & Imo1545 \\
\hline LMRG_00852 & acetyltransferase & 328 & 112 & $3.96 \mathrm{E}-04$ & 0.341463415 & Imo1400 \\
\hline LMRG_01385 & site-specific DNA-methyltransferase & 484 & 163 & $5.43 \mathrm{E}-04$ & 0.33677686 & Imo1582 \\
\hline LMRG_02473 & 30S ribosomal protein $\mathrm{S} 6$ & 520 & 175 & $4.20 \mathrm{E}-04$ & 0.336538462 & Imo0044 \\
\hline predicted RNA & - & 4219 & 1411 & 0.003535268 & 0.334439441 & $\# \mathrm{~N} / \mathrm{A}$ \\
\hline predicted RNA & - & 560 & 187 & 0.001804117 & 0.333928571 & $\# \mathrm{~N} / \mathrm{A}$ \\
\hline LMRG_02187 & serine/threonine protein phosphatase & 105 & 35 & $3.64 \mathrm{E}-04$ & 0.333333333 & Imo2642 \\
\hline LMRG_01230 & hypothetical protein & 42 & 14 & $9.19 \mathrm{E}-04$ & 0.333333333 & Imo2079 \\
\hline LMRG_01382 & protease IV & 36 & 12 & 0.002942662 & 0.333333333 & Imo1585 \\
\hline LMRG_01195 & 2-dehydropantoate 2-reductase & 30 & 10 & 0.004772802 & 0.333333333 & Imo2046 \\
\hline LMRG_01790 & phosphoglycerate kinase & 686 & 228 & $5.42 \mathrm{E}-04$ & 0.332361516 & Imo2458 \\
\hline LMRG_01098 & ScpA/B protein & 103 & 34 & $2.76 \mathrm{E}-05$ & 0.330097087 & Imo1951 \\
\hline LMRG_01059 & hypothetical protein & 73 & 24 & $3.33 \mathrm{E}-05$ & 0.328767123 & Imo1912 \\
\hline predicted RNA & - & 229 & 75 & 0.039007579 & 0.327510917 & $\# \mathrm{~N} / \mathrm{A}$ \\
\hline LMRG_00736 & DNA topoisomerase IV B subunit & 513 & 168 & 0.005301755 & 0.32748538 & Imo1286 \\
\hline LMRG_01058 & hypothetical protein & 43 & 14 & $8.40 \mathrm{E}-04$ & 0.325581395 & Imo1911 \\
\hline LMRG_01997 & aldo/keto reductase family oxidoreductase & 83 & 27 & $4.52 \mathrm{E}-05$ & 0.325301205 & $\operatorname{Imo} 2700$ \\
\hline LMRG_02122 & response regulator LiaR & 163 & 53 & $1.52 \mathrm{E}-05$ & 0.325153374 & Imo1022 \\
\hline LMRG_00084 & hypothetical protein & 114 & 37 & 0.00194844 & 0.324561404 & $\operatorname{Imo0391}$ \\
\hline LMRG_00762 & hypothetical protein & 37 & 12 & 0.027913956 & 0.324324324 & $\operatorname{Imo1312}$ \\
\hline LMRG_00085 & hypothetical protein & 130 & 42 & $5.72 \mathrm{E}-06$ & 0.323076923 & Imo0392 \\
\hline LMRG_01441 & hypothetical protein & 78 & 25 & 0.003860523 & 0.320512821 & Imo1529 \\
\hline LMRG_02900 & beta-glucoside operon transcriptional antiterminator & 94 & 30 & $8.10 \mathrm{E}-06$ & 0.319148936 & Imo2773 \\
\hline LMRG_01713 & ATP synthase F0 A subunit & 421 & 134 & $1.23 \mathrm{E}-04$ & 0.318289786 & Imo2535 \\
\hline LMRG_02658 & 50S ribosomal protein $\mathrm{L} 11$ & 2141 & 680 & $5.50 \mathrm{E}-04$ & 0.317608594 & $\operatorname{Imo0248}$ \\
\hline
\end{tabular}


bioRxiv preprint doi: https://doi.org/10.1101/2020.05.25.115097; this version posted May 25, 2020. The copyright holder for this preprint (which was not certified by peer review) is the author/funder. All rights reserved. No reuse allowed without permission.

Supplemental Table 1

\begin{tabular}{|c|c|c|c|c|c|c|}
\hline LMRG_00287 & hypothetical protein & 41 & 13 & 0.019268586 & 0.317073171 & Imo0604 \\
\hline LMRG_00871 & hypothetical protein & 121 & 38 & $5.23 \mathrm{E}-06$ & 0.314049587 & Imo1419 \\
\hline LMRG_00475 & amino acid transporter AAT family protein & 287 & 90 & $9.08 \mathrm{E}-05$ & 0.31358885 & Imo0787 \\
\hline predicted RNA & - & 354 & 111 & 0.003199764 & 0.313559322 & $\# \mathrm{~N} / \mathrm{A}$ \\
\hline LMRG_02425 & membrane protein OxaA & 428 & 134 & $6.66 \mathrm{E}-05$ & 0.313084112 & Imo2854 \\
\hline LMRG_00759 & hypothetical protein & 48 & 15 & 0.004644073 & 0.3125 & Imo1309 \\
\hline LMRG_02516 & glutamyl-tRNA(Gln) amidotransferase subunit A & 308 & 96 & $1.24 \mathrm{E}-04$ & 0.311688312 & Imo1755 \\
\hline LMRG_00163 & cfr family radical SAM enzyme & 289 & 90 & $7.62 \mathrm{E}-05$ & 0.311418685 & Imo0482 \\
\hline LMRG_00749 & glutamine synthetase type I & 621 & 191 & $1.08 \mathrm{E}-04$ & 0.307568438 & Imo1299 \\
\hline LMRG_02485 & adenylosuccinate synthetase & 154 & 47 & $2.18 \mathrm{E}-05$ & 0.305194805 & Imo0055 \\
\hline LMRG_00942 & hypothetical protein & 59 & 18 & 0.009270389 & 0.305084746 & Imo1489 \\
\hline LMRG_00216 & hypothetical protein & 69 & 21 & $5.69 \mathrm{E}-06$ & 0.304347826 & Imo0534 \\
\hline LMRG_00774 & hypothetical protein & 793 & 241 & 8.03E-06 & 0.303909206 & Imo1324 \\
\hline LMRG_02868 & AAT family amino acid transporter & 33 & 10 & $4.88 \mathrm{E}-04$ & 0.303030303 & Imo0798 \\
\hline LMRG_00377 & hypothetical protein & 33 & 10 & 0.001095668 & 0.303030303 & Imo0689 \\
\hline LMRG_01981 & ABC transporter CydDC cysteine exporter CydC & 308 & 93 & $5.50 \mathrm{E}-05$ & 0.301948052 & Imo2715 \\
\hline LMRG_02279 & UDP-N-acetylmuramoylalanyl-D-glutamyl-2 & 170 & 51 & $7.76 \mathrm{E}-06$ & 0.3 & Imo0856 \\
\hline LMRG_01891 & hypothetical protein & 47 & 14 & 0.004544726 & 0.29787234 & Imo2805 \\
\hline LMRG_01637 & peptide/nickel transport system permease & 1132 & 336 & $7.25 \mathrm{E}-04$ & 0.296819788 & Imo2195 \\
\hline LMRG_02751 & hypothetical protein & 118 & 35 & $7.56 \mathrm{E}-06$ & 0.296610169 & Imo0186 \\
\hline LMRG_00955 & malonyl CoA-acyl carrier protein transacylase & 98 & 29 & $2.02 \mathrm{E}-06$ & 0.295918367 & Imo1808 \\
\hline LMRG_00223 & $\begin{array}{l}\text { iron complex transport system substrate-binding } \\
\text { protein }\end{array}$ & 122 & 36 & $1.29 \mathrm{E}-06$ & 0.295081967 & Imo0541 \\
\hline LMRG_00288 & hypothetical protein & 75 & 22 & $3.80 \mathrm{E}-06$ & 0.293333333 & Imo0605 \\
\hline LMRG_01979 & cytochrome d ubiquinol oxidase subunit II & 580 & 170 & $2.49 \mathrm{E}-05$ & 0.293103448 & Imo2717 \\
\hline LMRG_02153 & $50 S$ ribosomal protein L36 & 3824 & 1111 & $1.42 \mathrm{E}-05$ & 0.290533473 & Imo2609 \\
\hline LMRG_01252 & pyridoxine biosynthesis protein & 341 & 99 & $1.11 \mathrm{E}-05$ & 0.290322581 & Imo2101 \\
\hline LMRG_01182 & cell division protein FtsA & 428 & 124 & $1.93 \mathrm{E}-05$ & 0.289719626 & Imo2033 \\
\hline LMRG_02671 & $\begin{array}{l}\text { 2-C-methyl-D-erythritol 4-phosphate } \\
\text { cytidylyltransferase }\end{array}$ & 2304 & 665 & $2.72 \mathrm{E}-04$ & 0.288628472 & Imo0235 \\
\hline predicted RNA & antisense: LMRG_01430 LMRG_01429 & 427 & 123 & 0.001841892 & 0.288056206 & $\# \mathrm{~N} / \mathrm{A}$ \\
\hline LMRG_02114 & $\begin{array}{l}\text { glycine betaine/proline transport system ATP-binding } \\
\text { protein }\end{array}$ & 293 & 84 & $9.67 \mathrm{E}-06$ & 0.28668942 & Imo1014 \\
\hline LMRG_00263 & SAM-dependent methyltransferase & 155 & 44 & $1.07 \mathrm{E}-05$ & 0.283870968 & Imo0581 \\
\hline LMRG_05004 & Lys tRNA & 2329 & 660 & $7.03 \mathrm{E}-06$ & 0.283383426 & $\# \mathrm{~N} / \mathrm{A}$ \\
\hline LMRG_01489 & hypothetical protein & 120 & 34 & $1.09 \mathrm{E}-05$ & 0.283333333 & Imo2354 \\
\hline LMRG_01771 & UDP-glucose 4-epimerase & 110 & 31 & $3.42 \mathrm{E}-07$ & 0.281818182 & Imo2477 \\
\hline LMRG_02510 & neurotransmitter: $\mathrm{Na}+$ symporter & 64 & 18 & $3.12 \mathrm{E}-07$ & 0.28125 & Imo1761 \\
\hline LMRG_01242 & argininosuccinate lyase & 25 & 7 & $3.35 \mathrm{E}-04$ & 0.28 & Imo2091 \\
\hline LMRG_01331 & $\begin{array}{l}\text { DNA binding 3-demethylubiquinone-9 3- } \\
\text { methyltransferase domain-containing protein }\end{array}$ & 193 & 54 & $3.19 \mathrm{E}-07$ & 0.279792746 & $\operatorname{Imo1635}$ \\
\hline LMRG_02081 & hypothetical protein & 175 & 48 & $6.10 \mathrm{E}-07$ & 0.274285714 & Imo0981 \\
\hline LMRG_01866 & glycerate kinase & 77 & 21 & $1.60 \mathrm{E}-07$ & 0.272727273 & Imo2832 \\
\hline predicted RNA & - & 837 & 228 & $2.67 E-05$ & 0.272401434 & $\# \mathrm{~N} / \mathrm{A}$ \\
\hline LMRG_01718 & ATP synthase F1 gamma subunit & 788 & 213 & $2.31 \mathrm{E}-06$ & 0.270304569 & Imo2530 \\
\hline LMRG_01018 & phosphomannomutase & 37 & 10 & $1.37 \mathrm{E}-05$ & 0.27027027 & Imo1871 \\
\hline
\end{tabular}


bioRxiv preprint doi: https://doi.org/10.1101/2020.05.25.115097; this version posted May 25, 2020. The copyright holder for this preprint (which was not certified by peer review) is the author/funder. All rights reserved. No reuse allowed without permission.

Supplemental Table 1

\begin{tabular}{|c|c|c|c|c|c|c|}
\hline LMRG_02183 & NADH dehydrogenase & 592 & 160 & $5.06 \mathrm{E}-05$ & 0.27027027 & Imo2638 \\
\hline LMRG_01013 & phosphotransferase & 26 & 7 & 0.00230137 & 0.269230769 & Imo1866 \\
\hline LMRG_02798 & hypothetical protein & 272 & 73 & $2.06 \mathrm{E}-06$ & 0.268382353 & Imo2142 \\
\hline predicted RNA & - & 358 & 96 & 0.011052388 & 0.268156425 & $\# \mathrm{~N} / \mathrm{A}$ \\
\hline LMRG_02864 & hypothetical protein & 64 & 17 & 0.001034586 & 0.265625 & $\# \mathrm{~N} / \mathrm{A}$ \\
\hline LMRG_00810 & hypothetical protein & 57 & 15 & $2.40 \mathrm{E}-05$ & 0.263157895 & Imo1360 \\
\hline LMRG_02626 & actin-assembly inducing protein ActA & 153 & 40 & $1.42 \mathrm{E}-07$ & 0.261437908 & Imo0204 \\
\hline LMRG_01364 & aminopeptidase & 153 & 40 & $2.03 \mathrm{E}-07$ & 0.261437908 & Imo1603 \\
\hline LMRG_01003 & purine nucleoside phosphorylase & 81 & 21 & $2.60 \mathrm{E}-06$ & 0.259259259 & Imo1856 \\
\hline LMRG_00381 & flagellar motor switch protein FliN/FliY & 722 & 185 & $2.34 \mathrm{E}-07$ & 0.256232687 & Imo0693 \\
\hline LMRG_02710 & CTP synthase & 594 & 152 & $6.70 \mathrm{E}-07$ & 0.255892256 & Imo2559 \\
\hline LMRG_01341 & hypothetical protein & 43 & 11 & $7.57 \mathrm{E}-07$ & 0.255813953 & Imo1625 \\
\hline LMRG_05050 & His tRNA & 232 & 59 & $6.68 \mathrm{E}-04$ & 0.254310345 & $\# \mathrm{~N} / \mathrm{A}$ \\
\hline predicted RNA & - & 284 & 72 & 0.005807016 & 0.253521127 & $\# \mathrm{~N} / \mathrm{A}$ \\
\hline predicted RNA & - & 222 & 56 & 0.005060871 & 0.252252252 & $\# \mathrm{~N} / \mathrm{A}$ \\
\hline LMRG_01488 & hypothetical protein & 282 & 71 & $1.21 \mathrm{E}-07$ & 0.25177305 & Imo2355 \\
\hline LMRG_00553 & hypothetical protein & 64 & 16 & $7.57 \mathrm{E}-07$ & 0.25 & Imo1091 \\
\hline LMRG_00393 & hypothetical protein & 128 & 32 & $2.24 \mathrm{E}-06$ & 0.25 & Imo0704 \\
\hline LMRG_02496 & AlR carboxylase & 40 & 10 & $3.98 \mathrm{E}-04$ & 0.25 & Imo1775 \\
\hline LMRG_02070 & D-alanine transfer protein & 1034 & 255 & $2.17 \mathrm{E}-05$ & 0.246615087 & Imo0971 \\
\hline LMRG_02872 & hypothetical protein & 1602 & 393 & $8.01 \mathrm{E}-08$ & 0.245318352 & Imo0694 \\
\hline predicted RNA & - & 213 & 52 & 0.001184674 & 0.244131455 & $\# \mathrm{~N} / \mathrm{A}$ \\
\hline LMRG_02827 & translation initiation factor IF-3 & 4106 & 997 & $2.11 \mathrm{E}-06$ & 0.242815392 & Imo1785 \\
\hline predicted RNA & - & 5311 & 1286 & $3.68 \mathrm{E}-08$ & 0.242138957 & $\# \mathrm{~N} / \mathrm{A}$ \\
\hline LMRG_00384 & hypothetical protein & 2429 & 588 & $3.52 \mathrm{E}-07$ & 0.242074928 & Imo0695 \\
\hline LMRG_00843 & simple sugar transport system permease & 87 & 21 & $4.89 \mathrm{E}-09$ & 0.24137931 & Imo1391 \\
\hline LMRG_01659 & hypothetical protein & 29 & 7 & $1.10 \mathrm{E}-05$ & 0.24137931 & Imo2173 \\
\hline LMRG_00772 & transcription termination factor NusA & 287 & 69 & $2.34 \mathrm{E}-09$ & 0.240418118 & Imo1322 \\
\hline predicted RNA & - & 887 & 213 & $1.16 \mathrm{E}-07$ & 0.240135287 & $\# \mathrm{~N} / \mathrm{A}$ \\
\hline LMRG_01712 & ATP synthase I & 150 & 36 & $2.41 \mathrm{E}-07$ & 0.24 & Imo2536 \\
\hline LMRG_00394 & flagellar hook-associated protein FlgK & 573 & 137 & $3.41 \mathrm{E}-08$ & 0.239092496 & Imo0705 \\
\hline predicted RNA & antisense: LMRG_01792 & 176 & 42 & 8.59E-04 & 0.238636364 & $\# \mathrm{~N} / \mathrm{A}$ \\
\hline LMRG_02307 & membrane protein & 202 & 48 & $1.26 \mathrm{E}-09$ & 0.237623762 & Imo0883 \\
\hline LMRG_00819 & phosphate butyryltransferase & 131 & 31 & $7.29 \mathrm{E}-11$ & 0.236641221 & Imo1369 \\
\hline LMRG_00811 & exodeoxyribonuclease VII large subunit & 89 & 21 & $4.10 \mathrm{E}-10$ & 0.235955056 & Imo1361 \\
\hline LMRG_01867 & beta-phosphoglucomutase & 51 & 12 & $1.08 \mathrm{E}-05$ & 0.235294118 & Imo2831 \\
\hline predicted RNA & - & 290 & 68 & 0.001100033 & 0.234482759 & $\# \mathrm{~N} / \mathrm{A}$ \\
\hline LMRG_02321 & SulP family sulfate permease & 64 & 15 & $1.99 \mathrm{E}-10$ & 0.234375 & Imo0897 \\
\hline LMRG_02978 & hypothetical protein & 64 & 15 & 0.001125382 & 0.234375 & $\# \mathrm{~N} / \mathrm{A}$ \\
\hline LMRG_01636 & $\begin{array}{l}\text { peptide/nickel transport system substrate-binding } \\
\text { protein }\end{array}$ & 2391 & 560 & $1.75 \mathrm{E}-07$ & 0.234211627 & Imo2196 \\
\hline LMRG_00987 & $\begin{array}{l}\text { pyrimidine operon attenuation protein/uracil } \\
\text { phosphoribosyltransferase }\end{array}$ & 47 & 11 & $6.92 \mathrm{E}-05$ & 0.234042553 & Imo1840 \\
\hline LMRG_01978 & cytochrome bd-I oxidase subunit I & 159 & 37 & $1.15 \mathrm{E}-08$ & 0.232704403 & Imo2718 \\
\hline
\end{tabular}


bioRxiv preprint doi: https://doi.org/10.1101/2020.05.25.115097; this version posted May 25, 2020. The copyright holder for this preprint (which was not certified by peer review) is the author/funder. All rights reserved. No reuse allowed without permission.

Supplemental Table 1

\begin{tabular}{|c|c|c|c|c|c|c|}
\hline LMRG_00803 & hypothetical protein & 86 & 20 & 5.80E-09 & 0.23255814 & Imo1353 \\
\hline LMRG_02136 & CRISPR-associated protein cas2 & 56 & 13 & $3.17 \mathrm{E}-04$ & 0.232142857 & $\# \mathrm{~N} / \mathrm{A}$ \\
\hline predicted RNA & - & 358 & 83 & 0.001804117 & 0.231843575 & \#N/A \\
\hline LMRG_01583 & hypothetical protein & 986 & 228 & 8.19E-09 & 0.231237323 & Imo2248 \\
\hline LMRG_01213 & hypothetical protein & 39 & 9 & $7.00 \mathrm{E}-04$ & 0.230769231 & Imo2063 \\
\hline LMRG_01676 & hypothetical protein & 39 & 9 & 7.11E-04 & 0.230769231 & Imo2156 \\
\hline LMRG_02071 & D-alanine--poly(phosphoribitol) ligase subunit 2 & 1124 & 259 & $7.20 \mathrm{E}-10$ & 0.230427046 & Imo0972 \\
\hline LMRG_02426 & ribonuclease $\mathrm{P}$ & 211 & 48 & $4.46 \mathrm{E}-09$ & 0.227488152 & Imo2855 \\
\hline LMRG_01741 & cell division ATP-binding protein FtsE & 721 & 163 & $6.66 \mathrm{E}-10$ & 0.226074896 & Imo2507 \\
\hline LMRG_00981 & $\begin{array}{l}\text { dihydroorotate dehydrogenase electron transfer } \\
\text { subunit }\end{array}$ & 49 & 11 & $3.31 \mathrm{E}-06$ & 0.224489796 & Imo1834 \\
\hline LMRG_01743 & D-glutamyl-L-m-Dpm peptidase P45 & 1944 & 436 & $9.47 \mathrm{E}-08$ & 0.224279835 & Imo2505 \\
\hline LMRG_00956 & fatty acid/phospholipid synthesis protein PIsX & 90 & 20 & $1.29 \mathrm{E}-10$ & 0.222222222 & Imo1809 \\
\hline predicted RNA & - & 389 & 86 & $3.72 \mathrm{E}-05$ & 0.221079692 & $\# \mathrm{~N} / \mathrm{A}$ \\
\hline predicted RNA & - & 242 & 53 & $2.11 \mathrm{E}-04$ & 0.219008264 & $\# \mathrm{~N} / \mathrm{A}$ \\
\hline predicted RNA & - & 256 & 56 & $2.67 \mathrm{E}-04$ & 0.21875 & $\# \mathrm{~N} / \mathrm{A}$ \\
\hline LMRG_01788 & transcriptional regulator & 719 & 156 & $3.22 \mathrm{E}-10$ & 0.216968011 & Imo2460 \\
\hline LMRG_00957 & fatty acid biosynthesis transcriptional regulator & 598 & 129 & $4.58 \mathrm{E}-12$ & 0.215719064 & $\operatorname{Imo1810}$ \\
\hline LMRG_01577 & $\begin{array}{l}\text { AGZA family MFS transporter xanthine/uracil } \\
\text { permease }\end{array}$ & 182 & 39 & $2.34 \mathrm{E}-10$ & 0.214285714 & Imo2254 \\
\hline LMRG_01453 & nitrogen regulatory protein $\mathrm{P}$-II & 33 & 7 & $5.43 \mathrm{E}-04$ & 0.212121212 & Imo1517 \\
\hline LMRG_00391 & hypothetical protein & 496 & 105 & $3.72 \mathrm{E}-11$ & 0.211693548 & Imo0702 \\
\hline LMRG_02060 & protease & 177 & 37 & $7.11 \mathrm{E}-12$ & 0.209039548 & $\operatorname{Imo0961}$ \\
\hline LMRG_02270 & glutamine $\mathrm{ABC}$ transporter & 144 & 30 & $2.32 \mathrm{E}-13$ & 0.208333333 & Imo0847 \\
\hline predicted RNA & - & 221 & 46 & $7.94 \mathrm{E}-06$ & 0.208144796 & $\# \mathrm{~N} / \mathrm{A}$ \\
\hline LMRG_00087 & extracellular P60 protein & 135 & 28 & $2.80 \mathrm{E}-11$ & 0.207407407 & Imo0394 \\
\hline LMRG_00151 & hypothetical protein & 92 & 19 & $6.63 \mathrm{E}-08$ & 0.206521739 & $\# \mathrm{~N} / \mathrm{A}$ \\
\hline LMRG_01742 & cell division transport system permease & 762 & 157 & $2.04 \mathrm{E}-11$ & 0.206036745 & Imo2506 \\
\hline LMRG_00535 & $\begin{array}{l}\text { iron complex transport system substrate-binding } \\
\text { protein }\end{array}$ & 68 & 14 & $2.93 \mathrm{E}-09$ & 0.205882353 & Imo1073 \\
\hline predicted RNA & - & 787 & 162 & $4.55 \mathrm{E}-09$ & 0.205844981 & $\# \mathrm{~N} / \mathrm{A}$ \\
\hline predicted RNA & - & 254 & 52 & $7.39 \mathrm{E}-06$ & 0.204724409 & $\# \mathrm{~N} / \mathrm{A}$ \\
\hline LMRG_00386 & flagellar hook protein FlgE & 362 & 74 & $8.09 \mathrm{E}-12$ & 0.20441989 & Imo0697 \\
\hline LMRG_02607 & oligopeptide transport system permease oppC & 54 & 11 & $2.17 \mathrm{E}-12$ & 0.203703704 & Imo0269 \\
\hline LMRG_00370 & flagellar basal-body rod protein FlgG & 54 & 11 & $2.43 \mathrm{E}-07$ & 0.203703704 & Imo0682 \\
\hline LMRG_01980 & ABC transporter CydDC cysteine exporter CydD & 430 & 87 & $1.19 \mathrm{E}-11$ & 0.202325581 & Imo2716 \\
\hline LMRG_01073 & chorismate mutase & 195 & 39 & $4.57 \mathrm{E}-11$ & 0.2 & Imo1926 \\
\hline LMRG_01428 & $50 S$ ribosomal protein $\mathrm{L} 21$ & 6089 & 1215 & $3.38 \mathrm{E}-08$ & 0.199540154 & Imo1542 \\
\hline LMRG_00395 & flagellar hook-associated protein 3 & 517 & 101 & $2.40 \mathrm{E}-13$ & 0.195357834 & Imo0706 \\
\hline LMRG_02773 & hypothetical protein & 385 & 75 & $4.01 \mathrm{E}-15$ & 0.194805195 & Imo1699 \\
\hline LMRG_02134 & hypothetical protein & 423 & 82 & $1.41 \mathrm{E}-16$ & 0.193853428 & Imo2594 \\
\hline predicted RNA & - & 301 & 58 & $9.22 \mathrm{E}-06$ & 0.19269103 & $\# \mathrm{~N} / \mathrm{A}$ \\
\hline LMRG_02073 & D-alanine--poly(phosphoribitol) ligase subunit 1 & 270 & 52 & $2.81 \mathrm{E}-14$ & 0.192592593 & Imo0974 \\
\hline predicted RNA & antisense: LMRG_01691 & 203 & 39 & $1.42 \mathrm{E}-05$ & 0.192118227 & $\# \mathrm{~N} / \mathrm{A}$ \\
\hline LMRG_01472 & O-methyltransferase & 73 & 14 & $1.24 \mathrm{E}-09$ & 0.191780822 & $\operatorname{Imo1498}$ \\
\hline
\end{tabular}


bioRxiv preprint doi: https://doi.org/10.1101/2020.05.25.115097; this version posted May 25, 2020. The copyright holder for this preprint (which was not certified by peer review) is the author/funder. All rights reserved. No reuse allowed without permission.

Supplemental Table 1

\begin{tabular}{|c|c|c|c|c|c|c|}
\hline predicted RNA & - & 335 & 64 & $1.11 \mathrm{E}-05$ & 0.191044776 & $\# \mathrm{~N} / \mathrm{A}$ \\
\hline LMRG_02624 & listeriolysin $\mathrm{O}$ & 168 & 32 & $1.15 \mathrm{E}-13$ & 0.19047619 & Imo0202 \\
\hline LMRG_00398 & hypothetical protein & 2607 & 494 & $7.01 \mathrm{E}-14$ & 0.189489835 & Imo0709 \\
\hline predicted RNA & antisense: LMRG_02182 & 431 & 81 & $9.73 \mathrm{E}-15$ & 0.187935035 & $\# \mathrm{~N} / \mathrm{A}$ \\
\hline LMRG_02783 & enoyl-(acyl carrier protein) reductase & 256 & 48 & $5.67 \mathrm{E}-15$ & 0.1875 & Imo0814 \\
\hline LMRG_01791 & triosephosphate isomerase & 659 & 123 & $9.75 \mathrm{E}-15$ & 0.186646434 & Imo2457 \\
\hline LMRG_00761 & hypothetical protein & 70 & 13 & $2.10 \mathrm{E}-12$ & 0.185714286 & Imo1311 \\
\hline LMRG_00389 & flagellar motor switch protein FliN/FliY & 890 & 165 & $2.56 \mathrm{E}-14$ & 0.185393258 & Imo0700 \\
\hline LMRG_01744 & hypothetical protein & 65 & 12 & $5.56 \mathrm{E}-12$ & 0.184615385 & Imo2504 \\
\hline predicted RNA & - & 378 & 68 & $2.00 \mathrm{E}-06$ & 0.17989418 & $\# \mathrm{~N} / \mathrm{A}$ \\
\hline LMRG_00388 & flagellar motor switch protein FliM & 1078 & 191 & $2.38 \mathrm{E}-16$ & 0.177179963 & Imo0699 \\
\hline LMRG_00953 & acyl carrier protein & 362 & 64 & $1.58 \mathrm{E}-14$ & 0.17679558 & Imo1806 \\
\hline predicted RNA & - & 665 & 117 & $1.11 \mathrm{E}-10$ & 0.17593985 & $\# \mathrm{~N} / \mathrm{A}$ \\
\hline LMRG_00104 & hypothetical protein & 74 & 13 & $2.12 \mathrm{E}-11$ & 0.175675676 & Imo0412 \\
\hline LMRG_00215 & ACT domain-containing protein & 74 & 13 & $2.26 \mathrm{E}-07$ & 0.175675676 & Imo0533 \\
\hline LMRG_00390 & hypothetical protein & 274 & 48 & $5.67 \mathrm{E}-19$ & 0.175182482 & Imo0701 \\
\hline LMRG_00662 & bax protein & 190 & 33 & $7.49 \mathrm{E}-21$ & 0.173684211 & Imo1216 \\
\hline LMRG_01508 & hypothetical protein & 1747 & 301 & $1.15 \mathrm{E}-14$ & 0.172295363 & Imo2335 \\
\hline LMRG_00404 & flagellar assembly protein $\mathrm{H}$ & 2207 & 379 & $3.22 \mathrm{E}-17$ & 0.171726325 & Imo0715 \\
\hline LMRG_02138 & CRISPR-associated protein & 47 & 8 & $1.46 \mathrm{E}-21$ & 0.170212766 & $\# \mathrm{~N} / \mathrm{A}$ \\
\hline predicted RNA & - & 259 & 44 & $7.88 \mathrm{E}-07$ & 0.16988417 & $\# \mathrm{~N} / \mathrm{A}$ \\
\hline predicted RNA & - & 282 & 47 & $2.32 \mathrm{E}-07$ & 0.166666667 & $\# \mathrm{~N} / \mathrm{A}$ \\
\hline LMRG_00365 & flagellar biosynthetic protein FliQ & 571 & 95 & $4.06 \mathrm{E}-24$ & 0.166374781 & Imo0677 \\
\hline LMRG_00407 & hypothetical protein & 319 & 53 & $5.84 \mathrm{E}-24$ & 0.166144201 & Imo0718 \\
\hline LMRG_02746 & $\begin{array}{l}\text { multiple sugar transport system substrate-binding } \\
\text { protein }\end{array}$ & 103 & 17 & $3.42 \mathrm{E}-21$ & 0.165048544 & Imo0181 \\
\hline LMRG_00385 & flagellar hook capping protein & 1003 & 165 & $2.51 \mathrm{E}-22$ & 0.164506481 & Imo0696 \\
\hline LMRG_01715 & ATP synthase F0 subunit B & 1436 & 236 & $6.64 \mathrm{E}-20$ & 0.164345404 & Imo2533 \\
\hline LMRG_02238 & autolysin & 1956 & 321 & $1.78 \mathrm{E}-16$ & 0.164110429 & Imo2691 \\
\hline predicted RNA & - & 476 & 78 & $1.71 \mathrm{E}-10$ & 0.163865546 & $\# \mathrm{~N} / \mathrm{A}$ \\
\hline LMRG_00476 & hypothetical protein & 55 & 9 & $3.69 \mathrm{E}-21$ & 0.163636364 & Imo0788 \\
\hline LMRG_02379 & hypothetical protein & 110 & 18 & $9.32 \mathrm{E}-20$ & 0.163636364 & Imo0130 \\
\hline predicted RNA & - & 385 & 63 & $6.88 \mathrm{E}-08$ & 0.163636364 & $\# \mathrm{~N} / \mathrm{A}$ \\
\hline LMRG_01487 & hypothetical protein & 44 & 7 & $2.13 \mathrm{E}-06$ & 0.159090909 & $\# \mathrm{~N} / \mathrm{A}$ \\
\hline predicted RNA & - & 1512 & 236 & $6.50 \mathrm{E}-18$ & 0.156084656 & $\# \mathrm{~N} / \mathrm{A}$ \\
\hline LMRG_02059 & hypothetical protein & 154 & 24 & $2.94 \mathrm{E}-25$ & 0.155844156 & Imo0960 \\
\hline predicted RNA & - & 2547 & 383 & $7.86 \mathrm{E}-27$ & 0.150372988 & $\# \mathrm{~N} / \mathrm{A}$ \\
\hline LMRG_00840 & $\mathrm{ABC}$ transporter & 293 & 44 & $1.28 \mathrm{E}-24$ & 0.150170648 & Imo1388 \\
\hline predicted RNA & - & 181 & 27 & 1.95E-09 & 0.149171271 & $\# \mathrm{~N} / \mathrm{A}$ \\
\hline predicted RNA & - & 222 & 33 & $1.25 \mathrm{E}-09$ & 0.148648649 & $\# \mathrm{~N} / \mathrm{A}$ \\
\hline LMRG_02072 & membrane protein & 622 & 92 & $6.60 \mathrm{E}-26$ & 0.147909968 & Imo0973 \\
\hline predicted RNA & - & 325 & 48 & $1.43 \mathrm{E}-10$ & 0.147692308 & $\# \mathrm{~N} / \mathrm{A}$ \\
\hline LMRG_02623 & 1-phosphatidylinositol phosphodiesterase & 299 & 44 & $3.76 \mathrm{E}-31$ & 0.147157191 & Imo0201 \\
\hline
\end{tabular}


bioRxiv preprint doi: https://doi.org/10.1101/2020.05.25.115097; this version posted May 25, 2020. The copyright holder for this preprint (which was not certified by peer review) is the author/funder. All rights reserved. No reuse allowed without permission.

Supplemental Table 1

\begin{tabular}{|c|c|c|c|c|c|c|}
\hline LMRG_02306 & hypothetical protein & 367 & 54 & $2.22 \mathrm{E}-31$ & 0.147138965 & Imo0882 \\
\hline LMRG_00859 & pyruvate formate-lyase activating enzyme & 48 & 7 & $1.99 \mathrm{E}-11$ & 0.145833333 & Imo1407 \\
\hline LMRG_02137 & CRISPR-associated protein cas1 & 69 & 10 & $4.98 \mathrm{E}-17$ & 0.144927536 & $\# \mathrm{~N} / \mathrm{A}$ \\
\hline LMRG_00045 & long-chain fatty acid CoA ligase (AMP-binding) & 152 & 22 & $2.06 \mathrm{E}-33$ & 0.144736842 & Imo0354 \\
\hline LMRG_00402 & flagellar M-ring protein FliF & 1309 & 189 & $4.43 \mathrm{E}-19$ & 0.144385027 & Imo0713 \\
\hline LMRG_01507 & 1-phosphofructokinase & 791 & 111 & $3.77 \mathrm{E}-29$ & 0.140328698 & Imo2336 \\
\hline LMRG_01506 & hypothetical protein & 679 & 95 & $9.72 \mathrm{E}-33$ & 0.139911635 & Imo2337 \\
\hline LMRG_05005 & Leu tRNA & 1696 & 237 & $1.78 \mathrm{E}-30$ & 0.139740566 & $\# \mathrm{~N} / \mathrm{A}$ \\
\hline predicted RNA & - & 266 & 37 & $8.02 \mathrm{E}-10$ & 0.139097744 & \#N/A \\
\hline LMRG_01779 & APA family basic amino acid/polyamine antiporter & 72 & 10 & $3.67 E-23$ & 0.138888889 & Imo2469 \\
\hline LMRG_00760 & hypothetical protein & 36 & 5 & $1.02 \mathrm{E}-13$ & 0.138888889 & $\operatorname{Imo1310}$ \\
\hline LMRG_01376 & $\mathrm{N}$-acetyl-gamma-glutamyl-phosphate reductase & 58 & 8 & $2.16 \mathrm{E}-18$ & 0.137931034 & Imo1591 \\
\hline LMRG_00980 & dihydroorotate oxidase & 51 & 7 & $5.29 \mathrm{E}-14$ & 0.137254902 & Imo1833 \\
\hline LMRG_00400 & flagellar basal-body rod protein FlgC & 633 & 85 & $8.02 \mathrm{E}-41$ & 0.134281201 & Imo0711 \\
\hline LMRG_05035 & Leu tRNA & 1337 & 178 & $1.08 \mathrm{E}-27$ & 0.133133882 & $\# \mathrm{~N} / \mathrm{A}$ \\
\hline predicted RNA & - & 370 & 49 & $3.61 \mathrm{E}-11$ & 0.132432432 & $\# \mathrm{~N} / \mathrm{A}$ \\
\hline LMRG_00778 & tRNA pseudouridine synthase $B$ & 152 & 20 & $1.08 \mathrm{E}-32$ & 0.131578947 & Imo1328 \\
\hline LMRG_00399 & flagellar basal-body rod protein FlgB & 604 & 79 & $1.27 \mathrm{E}-41$ & 0.130794702 & $\operatorname{Imo} 0710$ \\
\hline predicted RNA & antisense: LMRG_01743 & 177 & 23 & $1.17 \mathrm{E}-10$ & 0.129943503 & $\# \mathrm{~N} / \mathrm{A}$ \\
\hline predicted RNA & - & 524 & 68 & $5.21 \mathrm{E}-20$ & 0.129770992 & $\# \mathrm{~N} / \mathrm{A}$ \\
\hline LMRG_02012 & nitrite transporter NirC & 509 & 66 & $3.81 \mathrm{E}-33$ & 0.129666012 & Imo0912 \\
\hline predicted RNA & - & 324 & 42 & $2.16 \mathrm{E}-18$ & 0.12962963 & $\# \mathrm{~N} / \mathrm{A}$ \\
\hline LMRG_01584 & hypothetical protein & 124 & 16 & $2.06 \mathrm{E}-16$ & 0.129032258 & $\# \mathrm{~N} / \mathrm{A}$ \\
\hline LMRG_00397 & flagellar biosynthesis protein fliS & 1993 & 257 & $5.01 \mathrm{E}-35$ & 0.12895133 & Imo0708 \\
\hline LMRG_00406 & hypothetical protein & 1247 & 160 & $1.60 \mathrm{E}-36$ & 0.128307939 & Imo0717 \\
\hline predicted RNA & - & 219 & 28 & $1.83 \mathrm{E}-13$ & 0.127853881 & $\# \mathrm{~N} / \mathrm{A}$ \\
\hline LMRG_01241 & argininosuccinate synthase & 90 & 11 & $5.43 \mathrm{E}-32$ & 0.122222222 & Imo2090 \\
\hline LMRG_00405 & flagellar protein export ATPase Flil & 550 & 66 & $1.79 \mathrm{E}-41$ & 0.12 & Imo0716 \\
\hline LMRG_00985 & aspartate carbamoyltransferase & 34 & 4 & $3.73 \mathrm{E}-18$ & 0.117647059 & Imo1838 \\
\hline predicted RNA & - & 1199 & 134 & $3.87 \mathrm{E}-22$ & 0.1117598 & $\# \mathrm{~N} / \mathrm{A}$ \\
\hline LMRG_00841 & simple sugar transport system ATP-binding protein & 127 & 14 & $1.26 \mathrm{E}-55$ & 0.11023622 & Imo1389 \\
\hline LMRG_00978 & orotate phosphoribosyltransferase & 37 & 4 & $3.01 \mathrm{E}-15$ & 0.108108108 & Imo1831 \\
\hline predicted RNA & - & 192 & 20 & $8.11 \mathrm{E}-19$ & 0.104166667 & $\# \mathrm{~N} / \mathrm{A}$ \\
\hline predicted RNA & - & 279 & 29 & $5.63 \mathrm{E}-31$ & 0.103942652 & \#N/A \\
\hline LMRG_00842 & simple sugar transport system permease & 165 & 17 & $5.55 \mathrm{E}-56$ & 0.103030303 & $\operatorname{Imo1390}$ \\
\hline LMRG_01579 & aspartate aminotransferase & 235 & 24 & $1.18 \mathrm{E}-75$ & 0.10212766 & Imo2252 \\
\hline LMRG_00403 & flagellar motor switch protein FliG & 592 & 60 & $8.87 \mathrm{E}-68$ & 0.101351351 & Imo0714 \\
\hline LMRG_01976 & acetyl-CoA synthetase & 773 & 78 & $8.55 \mathrm{E}-63$ & 0.100905563 & Imo2720 \\
\hline LMRG_00858 & formate acetyltransferase & 355 & 35 & $9.14 \mathrm{E}-72$ & 0.098591549 & Imo1406 \\
\hline LMRG_00984 & dihydroorotase & 64 & 6 & $1.11 \mathrm{E}-35$ & 0.09375 & Imo1837 \\
\hline LMRG_00376 & hypothetical protein & 270 & 25 & $2.17 \mathrm{E}-74$ & 0.092592593 & Imo0688 \\
\hline LMRG_00366 & flagellar biosynthesis protein FliR & 119 & 11 & $1.32 \mathrm{E}-41$ & 0.092436975 & Imo0678 \\
\hline
\end{tabular}


bioRxiv preprint doi: https://doi.org/10.1101/2020.05.25.115097; this version posted May 25, 2020. The copyright holder for this preprint (which was not certified by peer review) is the author/funder. All rights reserved. No reuse allowed without permission.

Supplemental Table 1

\begin{tabular}{|c|c|c|c|c|c|c|}
\hline LMRG_00387 & hypothetical protein & 338 & 31 & $2.43 E-45$ & 0.091715976 & Imo0698 \\
\hline predicted RNA & - & 1163 & 105 & $1.17 \mathrm{E}-62$ & 0.090283749 & $\# \mathrm{~N} / \mathrm{A}$ \\
\hline LMRG_00706 & hypothetical protein & 1530 & 137 & $4.97 \mathrm{E}-90$ & 0.089542484 & Imo1257 \\
\hline LMRG_00396 & flagellar hook-associated protein 2 & 1259 & 111 & $3.48 \mathrm{E}-82$ & 0.08816521 & Imo0707 \\
\hline LMRG_00401 & flagellar hook-basal body complex protein FliE & 337 & 29 & $6.46 \mathrm{E}-57$ & 0.086053412 & Imo0712 \\
\hline LMRG_00368 & flagellar biosynthesis protein FlhA & 95 & 8 & $1.26 \mathrm{E}-74$ & 0.084210526 & Imo0680 \\
\hline LMRG_02347 & mannose-specific PTS system IID component & 216 & 18 & $2.87 \mathrm{E}-83$ & 0.083333333 & Imo0098 \\
\hline LMRG_00364 & flagellar biosynthetic protein FliP & 410 & 34 & $6.85 \mathrm{E}-123$ & 0.082926829 & Imo0676 \\
\hline LMRG_05037 & Thr tRNA & 401 & 33 & $1.30 \mathrm{E}-37$ & 0.082294264 & $\# \mathrm{~N} / \mathrm{A}$ \\
\hline predicted RNA & - & 379 & 30 & $2.01 \mathrm{E}-36$ & 0.079155673 & $\# \mathrm{~N} / \mathrm{A}$ \\
\hline LMRG_00982 & carbamoyl-phosphate synthase large subunit & 89 & 7 & $2.07 \mathrm{E}-117$ & 0.078651685 & Imo1835 \\
\hline LMRG_02908 & hypothetical protein & 140 & 11 & $1.14 \mathrm{E}-38$ & 0.078571429 & $\# \mathrm{~N} / \mathrm{A}$ \\
\hline LMRG_00367 & flagellar biosynthetic protein FlhB & 272 & 21 & $5.76 \mathrm{E}-133$ & 0.077205882 & Imo0679 \\
\hline LMRG_01064 & formate acetyltransferase & 689 & 53 & $4.57 \mathrm{E}-119$ & 0.076923077 & Imo1917 \\
\hline predicted RNA & - & 281 & 21 & $3.94 \mathrm{E}-48$ & 0.074733096 & $\# \mathrm{~N} / \mathrm{A}$ \\
\hline LMRG_01580 & polar amino acid transport system ATP-binding protein & 436 & 32 & $5.02 \mathrm{E}-157$ & 0.073394495 & Imo2251 \\
\hline LMRG_01838 & hypothetical protein & 151 & 11 & $1.30 \mathrm{E}-66$ & 0.072847682 & Imo2410 \\
\hline LMRG_00979 & orotidine 5'-phosphate decarboxylase & 127 & 9 & $3.19 \mathrm{E}-70$ & 0.070866142 & Imo1832 \\
\hline LMRG_01269 & hypothetical protein & 466 & 33 & $3.13 \mathrm{E}-154$ & 0.070815451 & Imo2115 \\
\hline predicted RNA & - & 505 & 35 & $3.98 \mathrm{E}-56$ & 0.069306931 & $\# \mathrm{~N} / \mathrm{A}$ \\
\hline LMRG_00983 & carbamoyl-phosphate synthase small subunit & 130 & 9 & $8.52 \mathrm{E}-85$ & 0.069230769 & Imo1836 \\
\hline predicted RNA & - & 188 & 13 & $2.11 \mathrm{E}-45$ & 0.069148936 & $\# \mathrm{~N} / \mathrm{A}$ \\
\hline predicted RNA & - & 772 & 52 & $5.12 \mathrm{E}-116$ & 0.067357513 & $\# \mathrm{~N} / \mathrm{A}$ \\
\hline LMRG_02874 & flagellar motor switch protein FliN & 611 & 40 & $2.69 \mathrm{E}-133$ & 0.065466448 & Imo0675 \\
\hline LMRG_00374 & chemotaxis protein MotB & 872 & 54 & $7.09 \mathrm{E}-193$ & 0.061926606 & Imo0686 \\
\hline predicted RNA & - & 326 & 20 & $3.99 \mathrm{E}-66$ & 0.061349693 & $\# \mathrm{~N} / \mathrm{A}$ \\
\hline LMRG_00748 & HTH-type transcriptional regulator glnR & 87 & 5 & $1.99 \mathrm{E}-60$ & 0.057471264 & Imo1298 \\
\hline LMRG_01268 & hypothetical protein & 301 & 17 & $1.10 \mathrm{E}-188$ & 0.056478405 & Imo2114 \\
\hline predicted RNA & - & 341 & 19 & $2.61 \mathrm{E}-95$ & 0.055718475 & $\# \mathrm{~N} / \mathrm{A}$ \\
\hline LMRG_00369 & flagellar biosynthesis regulator FlhF & 222 & 12 & $2.50 \mathrm{E}-219$ & 0.054054054 & Imo0681 \\
\hline predicted RNA & - & 674 & 36 & $5.75 \mathrm{E}-87$ & 0.053412463 & $\# \mathrm{~N} / \mathrm{A}$ \\
\hline LMRG_00375 & hypothetical protein & 512 & 26 & $5.22 \mathrm{E}-242$ & 0.05078125 & Imo0687 \\
\hline predicted RNA & antisense: LMRG_01332 & 355 & 17 & $1.73 \mathrm{E}-116$ & 0.047887324 & $\# \mathrm{~N} / \mathrm{A}$ \\
\hline predicted RNA & - & 315 & 15 & $1.95 \mathrm{E}-118$ & 0.047619048 & $\# \mathrm{~N} / \mathrm{A}$ \\
\hline LMRG_02345 & mannose-specific PTS system IIAB component manL & 939 & 42 & 0 & 0.044728435 & Imo0096 \\
\hline predicted RNA & - & 249 & 11 & $1.37 \mathrm{E}-135$ & 0.044176707 & $\# \mathrm{~N} / \mathrm{A}$ \\
\hline LMRG_00046 & fumarate reductase flavoprotein subunit & 570 & 25 & 0 & 0.043859649 & Imo0355 \\
\hline LMRG_05003 & Thr tRNA & 412 & 18 & $1.15 \mathrm{E}-143$ & 0.04368932 & $\# \mathrm{~N} / \mathrm{A}$ \\
\hline predicted RNA & - & 208 & 9 & $1.68 \mathrm{E}-121$ & 0.043269231 & $\# \mathrm{~N} / \mathrm{A}$ \\
\hline LMRG_00373 & chemotaxis protein MotA & 849 & 36 & 0 & 0.042402827 & Imo0685 \\
\hline predicted RNA & - & 386 & 15 & $7.22 \mathrm{E}-180$ & 0.038860104 & $\# \mathrm{~N} / \mathrm{A}$ \\
\hline predicted RNA & antisense: LMRG_01332 & 284 & 11 & $5.53 \mathrm{E}-170$ & 0.038732394 & $\# \mathrm{~N} / \mathrm{A}$ \\
\hline
\end{tabular}


bioRxiv preprint doi: https://doi.org/10.1101/2020.05.25.115097; this version posted May 25, 2020. The copyright holder for this preprint (which was not certified by peer review) is the author/funder. All rights reserved. No reuse allowed without permission.

Supplemental Table 1

\begin{tabular}{|c|c|c|c|c|c|c|}
\hline LMRG_02346 & mannose-specific PTS system IIC component & 549 & 20 & 0 & 0.036429872 & $\operatorname{Imo0097}$ \\
\hline LMRG_00371 & chemotaxis protein methyltransferase & 191 & 6 & 0 & 0.031413613 & Imo0683 \\
\hline LMRG_00986 & uracil permease & 535 & 16 & 0 & 0.029906542 & Imo1839 \\
\hline predicted RNA & - & 373 & 11 & 0 & 0.029490617 & $\# \mathrm{~N} / \mathrm{A}$ \\
\hline predicted RNA & - & 606 & 13 & 0 & 0.021452145 & $\# \mathrm{~N} / \mathrm{A}$ \\
\hline LMRG_01332 & bifunctional acetaldehyde-CoA/alcohol dehydrogenase & 4772 & 98 & 0 & 0.020536463 & Imo1634 \\
\hline predicted RNA & - & 3702 & 61 & 0 & 0.01647758 & \#N/A \\
\hline LMRG_00372 & hypothetical protein & 1276 & 21 & 0 & 0.01645768 & Imo0684 \\
\hline LMRG_01479 & glutamate decarboxylase & 809 & 12 & 0 & 0.014833127 & Imo2363 \\
\hline predicted RNA & - & 237 & 3 & 0 & 0.012658228 & $\# \mathrm{~N} / \mathrm{A}$ \\
\hline predicted RNA & - & 660 & 8 & 0 & 0.012121212 & $\# \mathrm{~N} / \mathrm{A}$ \\
\hline LMRG_01480 & glutamate/gamma-aminobutyrate antiporter & 1094 & 12 & 0 & 0.010968921 & Imo2362 \\
\hline
\end{tabular}

